RESEARCH INSTITUTE OF PUBLIC LAW

\title{
ONE-TIME GROSS BREACH OF WORK DUTIES AS THE GROUND FOR TERMINATION OF THE EMPLOYMENT CONTRACT AT THE INITIATIVE OF THE EMPLOYER
}

Monograph

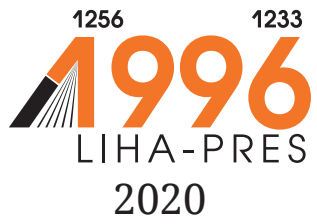


UDC 349.22:331.106.44

O-57

Recommended to be published by the Academic council of the Research Institute of Public Law

(protocol No. 10 on 14.09.2020)

\section{Reviewers:}

Inshyn M. I. - Head of the Department of Labour Law and Social Security Law of the Faculty of Law of Taras Shevchenko National University of Kyiv, Doctor of Law, Professor, Corresponding Member of the National Academy of Legal Sciences of Ukraine, Honoured Lawyer of Ukraine;

Mohilevskyi L. V. - Academic Secretary of the Secretariat of the Academic Council of Kharkiv National University of Internal Affairs, Doctor of Law, Professor

One-time gross breach of work duties as the ground for O-57 termination of the employment contract at the initiative of the employer : monograph / O. Yu. Drozd, S. M. Kozin. Lviv-Toruń : Liha-Pres. 2020. - 208 p.

ISBN 978-966-397-211-4

DOI

The monograph is devoted to the determination of the place of gross breach by the employee of his work duties in the system of additional grounds for termination of the employment contract at the initiative of the employer, as well as the scientific substantiation of the proposal and recommendations for improving the regulatory and legal practice in this area.

The scientifically substantiated suggestions on improvement of the legal regulation of termination of the employment contract on the initiative of the employer in case of one-time gross breach by the employee of his work duties are provided. It is determined that in order to facilitate enforcement practice, it is necessary to legislate on the concept of "gross breach of work duties". The list of categories of employees who can be dismissed on the basis of the onetime gross breach of work duties is given, and the procedure for termination of the employment contract in case of such circumstances is described.

The monograph is designed for scholars, postgraduates, students, practicing lawyers, and anyone who is interested in the subject of the topic.

UDC 349.22:331.106.44

The reference to this publication is obligatory in case of complete or partial reproduction of this monograph materials 


\section{CONTENTS}

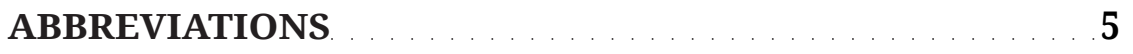

INTRODUCTION . . .

CHAPTER 1.

GENERAL LEGAL DESCRIPTION OF THE CONCEPT "GROSS BREACH OF WORK DUTIES"

1.1. Work Duties of an Employee:

Legal Nature and Types

1.2. Definition and Significant Features

of the Concept "Gross Breach

of Work Duties"

Conclusions to Chapter 1

CHAPTER 2.

COMPARATIVE STUDY OF LEGAL REGULATION

OF TERMINATION OF THE EMPLOYMENT CONTRACT

IN CASE OF ONE-TIME GROSS BREACH

OF WORK DUTIES

2.1. The Legal Background and History

of the Legal Framework for Dismissal

of the Employee in case

of One-Time Gross Breach

of Work Duties in Ukraine.

2.2. Foreign experience of legal regulation

of employee dismissal in case of one-time

gross breach of work duties.

Conclusions to Chapter 2. 


\section{CHAPTER 3. \\ LEGAL REGULATION OF EMPLOYMENT CONTRACT TERMINATION IN CASE OF ONE-TIME GROSS BREACH OF WORK DUTIES IN UKRAINE: CURRENT STATE OF AFFAIRS AND AREAS OF IMPROVEMENT}

3.1. Subjects of Dismissal in case

of One-time Gross Breach of Work Duties

3.2. The Procedure for Termination

of the Employment Contract in case

of One-Time Gross Breach of Work Duties

Conclusions to Chapter 3 


\title{
ABBREVIATIONS
}

\author{
ARC - Autonomous Republic Of Crimea \\ SSS of Ukraine - State Statistics Service of Ukraine \\ PAA of Ukraine - Public Affair Administration \\ SFI of Ukraine - State Financial Inspectorate \\ of Ukraine \\ SFS of Ukraine - State Fiscal Service of Ukraine \\ SPI Of Ukraine - State Price Inspection of Ukraine \\ Media - mass media \\ CEA - Classification of Economic Activities \\ LC of Ukraine - Labour Code of Ukraine \\ CMU - Cabinet of Ministers of Ukraine \\ CAO - Code of Ukraine on Administrative \\ Offenses \\ MSP of Ukraine - Ministry of Social Policy of Ukraine \\ ILO - International Labour Organization \\ CC of Ukraine - Civil Code of Ukraine
}




\section{INTRODUCTION}

On June 28, 1996, the adoption of the Constitution laid the foundations for Ukraine's development towards a market-based law-governed state. In this regard, the socio-economic transformations in Ukraine require the creation of a harmonious and effective system of labour law, the introduction of significant innovations in the mechanism of legal regulation of labour relations. Recently, the emphasis has shifted from public regulation of the economy to the contractual one, which has determined an increased importance of labour law concepts, including the concept of a employment contract. Its role and place in the arrangement of relations in the field of work are coursed by the free nature of the realization of the right to work in society. Empowering the employee and the employer to determine the fate of their employment contract is one of the direct freedom manifestations of the latter: those who have the right to enter into the contract at their own discretion should also be free in matters of termination. The ability to break the contract between the parties enables them to act most effectively. The financial and economic situation is often the reason why it is more advantageous for the employee and the employer to break the existing relations between them than to continue them. This situation can lead to significant damage to the legal entity or even its bankruptcy. This is especially relevant with regard to the management of enterprises, institutions, organizations and their separate divisions. The possibility of termination of the employment contract with a person who grossly breaches the work duties assigned to them, on the one hand, encourages the parties to employment relationships to clearly fulfil the 
terms of the contract concluded between them, and on the other, allows the employer to avoid irresponsible employees. We believe that this is the para. 1 of Part 1 of Art. 41 of the Labour Code of Ukraine, whereby an employment contract may be terminated at the initiative of the owner or his authorized body.

In the case of one-time gross breach of work duties by the head of the enterprise, institution, organization of all forms of ownership (suboffice, representative office, branch, other separate division), his/her deputies, chief accountant of the enterprise, institution, organization, his deputies, as well as officials of revenue and duties bodies nominated for special ranks and officials of central executive bodies implementing national policy in public financial control and price control.

Scientific and theoretical foundations of the study are the works of such well-known specialists in the field of labor law, as O. M. Akopova, M. H. Aleksandrov, V. M. Andriiv, P. B. Bazhanova, N. M. Vapniarchuk, K. M. Husov, M. I. Inshyn, Yu. V. Isaiev, M. M. Klemparskyi, V. S. Kovryhin, V. O. Kravchenko, O. M. Obushenko, Yu. P. Orlovskyi, S. M. Prylypko, O. I. Protsevskyi, A. I. Stavtseva, O. S. Khokhriakova, S. M. Chernous, O. M. Yaroshenko and others.

However, despite the value of the work of these scholars, the domestic study of labour law still lacks comprehensive research that would form a holistic concept of one-time gross breach of work duties as grounds for termination of the employment contract and provide a clear and logical response to an issue on its legal nature, the categories of employees to which it may be applied, the procedure for the exercise of the right by the owner or his authorized body, etc.

The purpose of the monograph is to find out the legal nature of gross breach by the employee, on the basis of the analysis of theoretical achievements, the current legislation of Ukraine, the general practice of its implementation, 
as well as to determine its place in the system of additional grounds for termination of the employment contract at the initiative of the employer, to provide scientifically sound suggestions and recommendations for improving regulatory and law application practices in this field.

Section 1 reveals the legal duties of the individual and his rights, which are a necessary means of legal impact on public relations. Neither right nor obligation exist without one another.

To enjoy any right is possible only in case of its being respected and adhered by others. Considering the priority between rights and obligations, we prefer the former, since we believe that the internal logic construction of legal matter is subordinate mainly to subjective rights, which at the level of the abstract idea of law and according to its very definition, are an active nodal centre of its own legal content.

The authors argue that the essential features of the category under study as a labour phenomenon are: (a) the breach has caused or could have caused substantial pecuniary or non-pecuniary damage to the rights or interests of the employee, employer or the State; (b) this concept is evaluative; (c) the subjects of the breach are special categories of employees established by law; (d) this breach is a disciplinary misdemeanour; (e) the breach may entail a dismissal of the employee at the initiative of the employer.

In the long term, both in the labour study and labour law, it is proposed to use 2 legal categories: (a) one-time material breaches of work duties for employees in general and (b) one-time gross breach of work duties for special categories of employees.

Section 2 proves that the formation and development of legal regulation of the phenomenon under study includes the periods as follows:

1st (1928-1969) the stated reason for dismissal is launched for managers and other decision makers, taking into account 
the nature of their work function. In the 60 s of the twentieth century, dismissals for one-time gross breach were applied to certain categories of employees, subject to the regulations and statutes on discipline (railway workers, workers and employees of the coal industry).

2nd (1970-1990) for the first time, the Principles of Labour Legislation of the USSR and the Union Republics and in the Labour Code of the USSR provide for one-time gross breach of work duties by employees, subject to disciplinary responsibility, as a separate special ground for their dismissal. In the 70's and 80's of the twentieth century, much more sectors of the national economy adopted discipline statutes, whereby the special ground for termination of the employment contract envisages committing a gross breach of work duties.

3rd (1991 until present) on March 20, 1991, the owner or his/her authorized body was given the right to terminate the employment contract with the heads of enterprise in case of one-time gross breach of their work duties. Subsequently, this right became modern and extended not only to the heads of enterprises and their separate divisions, but also to their deputies, to the chief accountants, their deputies, as well as to the officials of the revenue and duties bodies nominated for special ranks, and officials of central executive bodies implementing national policy in public financial control and price control.

Section 3 exposes the lack of regularity and logic in separating by the legislature officials of revenue and duties bodies bodies nominated for special ranks, as well as officials of central executive bodies implementing national policy in public financial control and price control, as subjects of discharge for one-time gross breach of work duties.

The authors argue that the possibility of terminating the employment contract at the initiative of the employer with the head of the legal entity or a separate structural division, 
his/her deputies, the chief accountant, his/her deputies, officials responsible for accounting, as well as with officials, covered by Statutes on discipline requires legislative consolidation.

It is claimed that the one-time gross breach of work duties is a type of discipline offenses by an employee. That is why the law application body must determine in what way this violation has been found, whether it could be the basis for the termination of the employment contract under para. 1 of Art. 41 of the Labour Code of Ukraine, whether the legal requirements regarding the terms and procedure of the disciplinary action application to a released person are observed.

This monograph is the first attempt in the Ukrainian labour law doctrine to comprehensively study one-time gross breach of work duties as a basis for termination of the employment contract at the initiative of the employer, to identify the problematic issues of legality compliance during the dismissal of the employee on this basis and formulate an author's approach to their solution using modern methods of cognition, taking into account the latest scientific achievements. 


\section{CHAPTER 1. GENERAL LEGAL DESCRIPTION OF THE CONCEPT "GROSS BREACH OF WORK DUTIES"}

\subsection{Work Duties of an Employee: Legal Nature and Types}

Each sector of law (labour law is no exception) is characterized by its own set of subjects, which together with the subject, method, functions, sources and principles determine its place and specific features in the general system of law.

Formation of the legal competence of labour law is characterized by objectivity and is related to the parties' acquisition of specific functions that require legal regulation of mutual behaviour, taking into account the interests of each of them, in their relations. According to L. A. Syrovatskaia, ignoring the specificities of labour law as an independent sector in developing the concept of its influence on labour relations cannot be positive ${ }^{1}$.

The accelerated development of economic, political, labour and other relations has led to the occurrence of numerous, and therefore, unordered or insufficiently ordered by provisions of law in force situations, whereby, according to V. V. Lazarev, it is difficult to "manage" even under the ideal rulemaking activity ${ }^{2}$.

We advocate the perspective of S. K. Zagainova that it is fundamentally false that law is impeccable, since every life

1 Syrovatskaia, L. A. Labor law. 2nd ed. M.: Yurist, 1998. 312 p.

2 Lazarev, V. V. Gaps in law and ways to address them. M.: Yurid. lit., 1974. 263 p. 
situation finds its proper statutory determination, while life always outstrips regulatory provisions that enshrine social relations only in statics ${ }^{1}$.

Due to the lack of clarity and consistency in the regulation of labour relations, employees often find themselves in a certain legal vacuum. In turn, the social and legal insecurity of the employee does not contribute to their being interested in the results of their work and in the stability of such relations. The challenge for the labour law of Ukraine is to create the legal framework required in modern conditions and aimed at achieving a balance of interests of the parties to the employment contract, economic growth, productivity enhancement and human well-being. The labour law provides for principles such as social justice, equality, promotion of progressive changes in conditions and content of work, creation of optimal organization of work and favourable production conditions for attraction of employees and development of the worker's personality, stimulation of labour and public activity, ensuring of employment.

Considering the labour law in general, not only the role of labour in public life, but also the substantial specificity of this sector of law should be taken into account. It derives from the specificities of the object of legal regulation, that is labour, the activity of a person who markets his/her workforce as a capacity for work. These goals can be achieved only in the conditions of high internal organization of the system of labour law, smoothness and consistency of the legal framework. The new Labour Code of Ukraine should unify all the rules and principles of labour law both Ukrainian and international, all general and universal rules of this sector of law. Gaps in legal regulation and duplicate rules should be eliminated.

1 Zagainova, S. K. Judicial precedent: Problems of law application. M.: NORMA, 2002. 176 p. 
However, there is no need to change everything in the law right now, to discard and forget all previous experience and achievements. The establishment of new provisions and concepts should be in association with the preservation of the former ones, justified and capable of acting effectively in the new environment. O. M. Yaroshenko argues that consistency must become an indispensable qualitative characteristic of the legal system being created. Nevertheless, it should be of an analytical and creative nature, rejecting only of legal provisions, which have not justified themselves, legalize command-administrative methods of management, restrict human and citizen's rights and freedoms ${ }^{1}$.

P. B. Bazhanova advocates that the subjects of labour law are participants of public relations regulated by this sector of law, who possess rights proclaimed by labour law, fulfil their obligations and are responsible ${ }^{2}$. Moreover, V. L. Kostiuk argues that the subjects of labour law are the participants of social and labour relations, who, according to its norms, are empowered to have, exercise (acquire, enjoy) labour rights and responsibilities, as well as to bear legal responsibility for the failure or improper performance of the latter ${ }^{3}$. The subject of labour law is transformed into the subject of labour relations at the moment when his potential opportunity to participate in legal relations begins to be realized in reality. At this point, the abstract legal links turn into concrete ones.

Incoherent social relations that make up the target of labour law (labour, working conditions, on ensuring their contractual regulation, employment, organization

\footnotetext{
1 Yaroshenko, O. M. Sources of Labour Law of Ukraine. Doctor's thesis. Yaroslav Mudryi National Law University. Kh., 2007. 476 p.

2 Bazhanova, P. B. Commercial organizations and entrepreneurs without the formation of a legal entity as subjects of Labor Law. Ph.D.'s thesis. Academy of Labor and Social Relations. M., 2004. 208 p.

3 Khutoryan, N. M., Inshyn, M. I., Prylypko, S. M., Yaroshenko, O. M. (Eds). Codification of the labour legislation of Ukraine. Kh.: FINN, 2009. 432 p.
} 
and management of work, vocational training, retraining and advanced training, in relation to the responsibility of employers supervising and controlling the observance of labour law, etc.), require a plurality of subjects inherent in this field.

Each individual subject has a specific set of rights and responsibilities, occupies a special place in the system. The internal legal relations of the subjects of labour law, by their objective content, together with the target and method of legal regulation of the sector determine the qualitative originality of its provisions and principles.

Considering the importance of resolving these issues at the regulatory level, V. L. Kostiuk proposes to include in the draft LL of Ukraine a separate section on the subjects of labour law, which shall determine: a) provisions on the list of subjects of labour law and social and labour relations or the conditions of their formation (occurrence); b) the framework for their legal status (labour legal personality); c) the main structural elements of the latter; d) the conditions for the acquisition of legal personality and its exercise; e) the general principles for the implementation, provision, guarantee and protection of the labour rights (labour powers) of participants of public relations and the promotion of proper performance of work duties by them; e) general rules for the interaction of these participants ${ }^{1}$.

We agree with A. M. Slusar's value approach to the classification of subjects of labour law, which points to the primary basis of law, to its true source, that is, the person whose legal qualities are the real substance from which all substances are formed, including the State and its bodies. From the scientist's perspective, the subjects of labour law of Ukraine are: (a) an employee as a primary subject of labour law, (b) an employer as a main subject of labour law,

1 Khutoryan, N. M., Inshyn, M. I., Prylypko, S. M., Yaroshenko, O. M. (Eds). Codification of the labour legislation of Ukraine. Kh.: FINN, 2009. 432 p. 
(c) derivative subjects of labour law from an employee (a job seeker; a disabled person who has received employment or professional injury illness; plaintiff or defendant in court, etc.), (d) officials of labour law (public bodies, trade unions, private employment agencies, labour disputes commissions, conciliation commissions, labour arbitrations, etc.) ${ }^{1}$.

Each individual subject of labour law has a certain set of rights and responsibilities, occupies a special place in a system consisting of potential participants in legal relations and systemic two-level links, of the sector (internal relations) and of all positive law in general (external relations), the latter providing the necessary interaction of labour law with related sector es. Internal legal relations of the subjects of labour law by their objective content together with the subject and method of legal regulation of the sector determine the qualitative originality of its rules and principles, thus forming the entire labour law of Ukraine.

According to Art. 43 of the Constitution of Ukraine ${ }^{2}$ everyone has the right to work, which includes the opportunity to earn a living by labour, which he/she freely chooses or to which he/she freely agrees (Part 1), and the State creates conditions for citizens to fully realise the right to work, guarantees equal opportunities in the choice of profession and of types of labour, implements programs of vocational education, training and retraining of personnel in accordance with social needs (Part 2).

At the beginning of the XXI century, V. M. Andriiv includes labour rights, in general, and rights to work, in particular, to the main development trends:

- orientation of the international community and developed countries towards the fullest recognition and consolidation of natural labour rights;

1 Slusar, A. M. The subjects of Labour Law of Ukraine. Doctor's thesis. Yaroslav Mudryi National Law University. Kh., 2011. 407 p.

2 Constitution of Ukraine. (No. 254k/96-VR of 28 June 1996). Vidomosti Verkhovnoi Rady Ukrainy, no.30, 1996. Art. 141. 
- increase in the trend not only for recognising but also for ensuring labour rights;

- unity of public and private principles in recognising and ensuring labour rights;

- global universalization of labour rights;

- strengthened value of world-wide (universal) and European labour rights standards and their impact on national labour law;

- increase in the level of labour rights protection;

- strengthened role of social dialogue in the mechanism of realization of labour rights;

- acquisition of new qualities by labour rights in the form of deepening and expanding their content;

- -increase in flexibility (differentiation and individualization) in the legal regulation of labour relations in combination with the provision of labour rights ${ }^{1}$.

In the framework of the right to work exercise, a person acquires a legal status of "employee". The latter is a natural person who works under an employment contract at an enterprise, institution or organization, regardless of the form of ownership and type of activity, or a natural person who, in accordance with the law, employs hired labour. The term "employee" applies equally to an employee who has already taken up a job and to a person seeking or about to start a job, already agreed upon, regardless of whether he/she accepted a job offer or concluded an employment contract. We advocate V. V. Lazor's conclusion that the subject of labour law is not just a citizen, but an employee ${ }^{2}$. Employees are the most numerous category of population. With regard

1 Andriiv, V. M. The system of labour rights of employees and the mechanism of their provision. Extended abstract of Doctor's thesis. National University Odessa Law Academy. O., 2012. 40 p.

2 Lazor, V. V. Problems of definition of the concept and legal status of the subjects of labour law in the modern labor legislation of Ukraine. Actual Problems of Law: Theory and Practice. Luhansk: SNU of V. Dal. 2006. No. 8. P. 22-30. 
to the legal situation, among the other categories of the latter, they are distinguished by employment relations with other subjects, that is employers, who are intended to properly organize and/or guarantee their ability to hired labour (job performance).

It is the employee who is the bearer of labour, while employment relations are a legal mediation of his/her labour activity. In turn, labour is the human essence, in fact, the very person for whom the State exists. O. V. Romashov argues that labour is an expedient activity of people aimed at creation of material and cultural values. It is a foundation, a prerequisite for their vital activity. Affecting the environment, changing and adapting it to their needs, people not only ensure their existence, but also create conditions for the progress of society ${ }^{1}$. Therefore, Art. 43 of the Basic Law of Ukraine provides for the right to manifest this human essence. Everything that goes after the word "includes" is outside the right to work, although it usually actively influences the will of the owner of the work. It concerns other rights and freedoms of man and citizen, duties of the State and citizen aimed at encouraging the exercise of the right to work, the development of human abilities, the creation of conditions for their improvement, their fair assessment, etc.

In addition, O. M. Akopova argues that employees should be recognised as bearers of hired labour ${ }^{2}$. The specificities of the latter are: (a) it is not self-determining, but dependent, performed on the basis of a voluntary agreement with the employer; (b) it is related to the performance of the intended work and to the appropriate remuneration for the work performed, as referred to in the contract with the employer. In its content, according to O. I. Protsevskyi, the concepts

1 Romashov, O. V. Sociology of labour. M.: Gardarika, 2001. 320 p.

2 Akopova, E. M. The modern labour agreement (contract). Rostov: Mart, 1998. $352 \mathrm{p}$. 
of "labour" and "work" are similar but far from being interchangeable. Labour is an integral function of human being, and work is, so to speak, an external form whereby labour is realized and which is created by the State. Work is created by social conditions, the level of development of machinery and technology ${ }^{1}$.

The employee, his/her legal status is the starting point for the construction of the system of labour law. Labour law by its nature and social purpose is humanistic. It is aimed at creating favourable conditions for labour and life of the working person. Therefore, the fundamental area of the labour law study is the emphasis on the employee as the central subject of labour law, the determination of his/her interest presumption, the constant development of legislation on the protection of his/her rights and interests.

Social relations, governed by law, between the employee and the employer regarding the use of hired labour of the former in the interests of the latter take on the form of employment relations. O. I. Protsevskyi sums up that relations between people in the process oflabour, manifested in specific, constantly repeated actions, require legal regulation. Law is essential in regulation of these actions. The State enforces legal regulation by the establishment of specific rules of law for the conduct of subjects of public relations ${ }^{2}$.

In the 70s of the twentieth century, in the textbook Soviet Labour Law, N. G. Alexandrov defined labour relations as friendly cooperation of people free from exploitation, as legal relations whereby one party (employee) is obliged to apply his/her labour force, being involved in the personnel

1 Protsevskyi, O. I. The new content of the right to work is the basis of reforming the labour legislation of Ukraine. Pravo Ukrainy. 1999. No. 6. P. 101-105.

2 Protsevskyi, A. I. The subject of Soviet Labour Law. M .: Yurid. lit., 1979. $209 \mathrm{p}$. 
of the enterprise (institution, business) and complying with the latter's internal labour arrangements, and the latter (the employer) is obliged to pay remuneration for work and to provide conditions of work that are safe for workers' health and favourable for productivity ${ }^{1}$. In general, this approach has not changed so far.

An employment contract is the legal basis for employment relations and the exercise of the right to work. As long as this contract is in force, the employment relations function and the right to work is exercised. Moreover, the dismissal terminates these legal relations and the exercise of the right to work at the enterprise, institution, organization. That is why the cases of termination of the employment contract at the request of the employer or a person who is not a party to the employment relations are strictly defined in law, and provisions regarding them are not subject to extensible interpretation. We advocate the perspective of M. M. Purei that the employment contract, as the most important legal form for the citizen to exercise his right to work, establishes the parties' agreement on the employment function, place and time of exercising this right, allows to specify the measure of work and other rights and obligations of the worker and employer ${ }^{2}$.

H. I. Chanysheva argues that individual labour relations are primary and supreme, because labour law derives from them, that is, from the conclusion of an employment contract between the employer and the employee. She states that this contract is a legal basis for the occurrence of individual labour relations regarding working time, rest time, discipline, regulation and remuneration, health protection of workers in the labour process, training and improvement

\footnotetext{
1 Aleksandrov, N. G. Soviet Labour Law. 3rd ed. M.: Gosyurizdat, 1963. $414 \mathrm{p}$.

2 Purei, M. M. The right to work in Ukraine under market economy. Ph.D.'s thesis. H. S. Skovoroda Kharkiv State Pedagogical University. Kh., 2002. 173 p.
} 
of their qualification, financial liability of the parties to the contract, etc. ${ }^{1}$.

Individual labour relations determine and course all other types of relations that make up the target of labour law. They are justified and appropriate to the extent that the development of labour relations in general requires. The employment relations establish a legal connection between the employee and the company. According to L. Ya. Gintzburg, this connection is always concrete, and arises between the employee concerned and the particular enterprise ${ }^{2}$.

According to ILO Recommendation No. 198 "On Employment Relationship” (2006) ${ }^{3}$, the national policy of the State should include measures to combat disguised forms of employment, other relationships that may include the use of other forms of contractual arrangements that hide the true legal status of the worker. Whereas disguised employment relationships occur when the employer treats an individual as other than an employee in a manner that hides his/her true legal status. The situations can arise where contractual arrangements have the effect of depriving workers of the protection they are due. For the purpose of facilitating the determination of the existence of an employment relationship, States should, within the framework of the national policy, consider the possibility of the following: (a) allowing a broad range of means for determining the existence of an employment relationship; (b) providing for a legal presumption that an employment relationship exists where one or more relevant indicators is present; (c) determining, following prior consultations with the representative organizations of employers and workers,

\footnotetext{
1 Chanysheva, H. I. Collective relations in the sphere of labour: Theoretical and legal aspect. A.: Yuryd. lit. 2001, 280 p.

2 Ginzburg, L. Ya. Socialist Labour Relations. M.: Nauka, 1977. 310 p.

3 ILO Recommendation on employment relations No. 198. (May 31, 2006). http://zakon4.rada.gov.ua/laws/show/993_529.
} 
that workers with certain characteristics, in general or in a particular sector, must be deemed to be either employed or self-employed.

States should consider the possibility of defining in their laws and regulations, or by other means, specific indicators of the existence of an employment relationship. Those indicators might include:

- the fact that the work: (a) is carried out according to the instructions and under the control of another party; (b) involves the integration of the worker in the organization of the enterprise; (c) is performed solely or mainly for the benefit of another person, personally by the worker, within specific working hours or at a workplace specified or agreed by the party requesting the work; (d) is of a particular duration and has a certain continuity; (e) requires the worker's availability (f) involves the provision of tools, materials and machinery by the party requesting the work;

- periodic payment of remuneration to the worker;

- the fact that such remuneration constitutes the worker's sole or principal source of income;

- provision of payment in kind, such as food, lodging or transport;

- recognition of entitlements such as weekly rest and annual holidays;

- payment by the party requesting the work for travel undertaken by the worker in order to carry out the work;

- absence of financial risk for the worker.

D. V. Sychov analyses the theoretical and sectoral developments concerning the nature and content of the legal relationship to distinguish the most important features of an individual employment relationship: (a) a bilateral volitional relation exists between the worker and the employer or his authorized body; (b) it is of legal nature because it is governed by labour law; (c) a voluntary volitional relation arises as a result of an employment contract; (d) individual 
employment relationships are a form, consequence or condition of actual individual employment relationships; (e) the conclusion of an employment contract has the effects of arising reciprocal rights and obligations for the parties to an individual employment relationship, under which the worker undertakes to perform a specific work function, in compliance with internal labour regulations, and the employer shall pay for his/her work and create conditions for worker's efficient performance ${ }^{1}$.

The will of the employee and the employer as participants in the employment relationship is realized through the exercise and fulfilment of their reciprocal rights and obligations. O. V. Smirnov argues that establishment of employment relations is regulation of the effective worker's performance, on the one hand, and the organization on whose behalf the administration acts, on the other. This activity concerns various aspects of relations in the field of labour: workers' performance of a specific labour function, remuneration for the results of their work, provision of normal conditions for work by the administration, etc. ${ }^{2}$. In this case, subjective labour law and the corresponding obligation form a legal link between the authorized and obliged parties to the employment contract. According to A. R. Matsuk, the basis of the worker's duty to perform a specific job function, which is the main content of individual labour relations, is industrial relations in the social division of labour, which are reflected in assigning workers to various fields of its application. Whereas, the employer's obligation to pay for the work according to its quantity and quality is based on industrial distribution, which is the opposite of production and is a form of labour reproduction. The link of the basic fundamental rights and obligations of the worker and

1 Sychov, D. V. Legal regulation of individual labour relationship. Ph.D.'s thesis. National University of Internal Affairs. Kh., 2005. 182 p.

2 Smirnov, O. V. (Ed.). Labour Law. M.: Prospect, 1997. 448 p. 
One-time gross breach of work duties as the ground for termination of the employment contract at the initiative of the employer

the employer, i.e. the performance of a labour function in compliance with the internal labour regulations and remuneration with the provision of proper conditions, is the main employment relationship that determines the content of individual labour relationships ${ }^{1}$.

Under formation of an innovative society and globalization of the world economy, the issue of establishing and ensuring basic labour rights with all signs of social and other fundamental rights of the individual, is of special relevancy. At the same time, they also have signs of legal identity. E. V. Krasnov argues that labour rights are less universal and apply only to subjects of individual and collective labour relationships. Their realization depends on the level of economic development of the State and is connected with fulfilling by the latter certain obligations in the field of social policy ${ }^{2}$. According to the contest, basic labour rights can be classified as providing and regulating working conditions, protective procedures, vocational guidance and training, public obligations regarding work and employment, equality of rights and opportunities, prohibition of discrimination and forced labour, social dialogue.

The central idea of objective law is the recognition that a person, as a subject of social activity, possesses individual freedom through the legitimization of the legal remedies of realizing his/her essential abilities, inclinations and needs, expressed mainly in his/her subjective rights, as well as in other legal options. Subjective law forms an energetic nodal ideological centre, a pole, or in other words, a layer of legal matter and naturally serves as a source of law in general. In legal life, according to M. I. Matuzov, it determines the type and extent of behaviour of subjects, empowers them to

1 Matsiuk, A. R. Labour relations of a developed socialist society. K.: Naukova dumka, 1984. 280 p.

2 Krasnov, Ye. V. Basic labour rights: International standards and legislation of Ukraine. Odessa National Law Academy. O., 2008. 206 p. 
gain certain social benefits and enjoy them, is a prerequisite for personal freedom of the individual, serves as a form of mediating the most important interests of citizens, a means of satisfying their material and spiritual needs, promotes the development and improvement of the individual, enhances his/her social and legal activity, provides a combination of individual, collective and public interests, is a legal expression of the relationship between the State and the individual, a means of implementing legal rules in specific and general legal relations ${ }^{1}$. Ye. M. Chernykh argues that performing important functions in society, subjective law is a key element of the mechanism of legal regulation, the largest and most important classification system of the law system, the most secured and guaranteed form of legal freedom, a legal remedy of access to and enjoyment of all social goods ${ }^{2}$.

Subjective labour law is a measure of possible behaviour, provided for the authorized subject of labour law in order to satisfy his/her interests ensured by the legal duties of other subjects of this law ${ }^{3}$. In other words, subjective law has an inherently binding nature, which is expressed not only in giving a person legal capacity but also in compelling him/her to behave properly.

Similar to other subjects of labour law, the employee has own rights. Article 2 "Fundamental Labour Rights of Workers" of the Labour Code of Ukraine ${ }^{4}$ primarily recognizes and establishes the right of citizens of Ukraine

1 Matuzov, N. I. Legal system and personality. Saratov: Saratov University, 1987. 294 p.

2 Chernykh, Ye. M. Objective and subjective law: Theoretical and legal aspects of correlation. Ph.D.'s thesis. Kyiv National University of Internal Affairs. K., 2008. 235 p.

3 Prylypko, S. M., Yaroshenko, O. M., Zhyhalkin, I. P. et al. Labour Law of Ukraine. 5th ed. Kh.: Pravo, 2014. 760 p.

4 Labour Code of Ukraine approved by Law of the USSR No. 322-VIII of 10 December 1971. Vidomosti Verkhovnoi Rady of the USSR, no. 50 (Appendix). 1971. Art. 375. 
to work, that is, to receive work with remuneration not less than the minimum established by the State, including the right to free choice of profession, occupation and work. These rights are guaranteed by the State. According to this article, workers also have the right: to rest in accordance with the laws on working day and week restriction and annual paid vacations, to healthy and safe working conditions, to trade unions and to the resolution of collective labour conflicts (disputes) in statutory procedure, to participation in the management of an enterprise, institution or organization, to financial support in the old-age social security procedure, as well as in cases of sickness, total or partial disability, to financial assistance in case of unemployment, to appeals to court to resolve labour disputes, regardless of the nature of the work performed or the position held, except in cases provided for by law and other rights established by law.

Moreover, an extended approach to the issue under consideration is observed in Art. 21 of the draft LC of Ukraine (registration No. 1658, text of December 27, 2014) ${ }^{1}$, where the basic rights include the right of a worker:

- to the work he/she freely chooses or to which he/she freely agrees, and to the termination of employment relationship;

- to equal opportunities and equal treatment of him/her in resolving the issue of employment, to equal work for equal pay, professional growth or dismissal;

- to respect for his dignity and honour, confidentiality of personal information and its protection;

- to unemployment protection, vocational training, retraining and advanced training;

- to special protection for underage persons against physical and moral risk in connection with employment relationship;

1 Draft Labour Code of Ukraine (Registration No. 1658 of 27 December 2014). http://w1.c1.rada.gov.ua/pls/zweb2/webproc4_1?pf3511 = 53221 . 
- to special maternity protection for working women;

- to labour rehabilitation and professional adaptation for disabled persons;

- to protection of labour rights for migrant workers;

- to protection for workers with family responsibilities against discrimination and to reconciliation, insofar as possible, of their work with family responsibilities;

- to adequate, safe and healthy working conditions, including the right to receive information on working conditions and occupational safety requirements, as well as the right to withdraw from work in conditions that do not meet the safety requirements;

- to a fair remuneration not lower than the minimum wage established by law, and its timely payment in full;

- to proper working and living conditions, related to the performance of the worker's obligations under the employment contract;

- to State guarantees and compensations provided by this Code, laws and other legal regulations in the field of labour;

- to compulsory state social insurance;

- to rest;

- to request of observance by the employer of the conditions of labour law, collective and employment contracts;

- to trade unions;

- to participation in collective negotiating;

- to strike;

- to compensation for damage to health or property in connection with the performance of work duties;

- to protection against unlawful discharge;

- to protection of their labour rights, including in court.

Considering the topic of the study, the employee's work duties will be under special focus.

According to $\mathrm{H}$. Grotius, natural law requires an individual to comply with the principle of "treaty compliance" as a basis 
for the existence of a proper order of mutual obligations between people. In any case, from this perspective, a duty is necessary because advice or other non-binding instructions do not deserve the title of "law" or "right"

Describing interrelation between the State and the individual will of the citizen, J.-J. Rousseau argues that duty and benefit encourage equally both parties to help each other. The philosopher recognises the use of human rights by a person without proper performance of public duties as the cause of the destruction of a political organism. Consequently, the need for a coercive moment in the relationship between the State and the citizen arises ${ }^{2}$. Therefore, the thinker interprets duty as a guarantee of the existence of the individual's rights and freedoms, because the rights, freedoms and obligations cannot exist separately, since it is impossible for one person to have only rights and the other only duties.

In the dogmatic doctrine, the categories "legal obligation" and "subjective law" are regarded as correlative. Furthermore, this connection makes some experts to recognise the obligation not only as a necessary companion of legal capacity, but also as a justification and even a reason for the existence of the latter, while a subjective right takes place only if the subjective obligation corresponds to it. Analytically the concept of "subjective law" is explained as a mere reflection of a duty where law is merely a reflection of the latter. According to $\mathrm{H}$. Kelsen, the reflexive right of one is only the duty of another ${ }^{3}$.

On the one hand, obligation as a concept is general in nature, because it sets out requirements that have the same meaning

1 Grotius, H. On the Law of War and Peace. Three books explaining natural law and the law of peoples, as well as the principles of Public Law. M.: Ladomir, 1994. $848 \mathrm{p}$.

2 Rousseau, J.-J. On a social contract, or Principles of political law. M.: Politizdat, 1969.

3 Kelsen, H. Pure Theory of Law. K.: University, 2004. 496 p. 
for most people and, on the other, more specific, because it reveals the content of the actions envisaged, indicating what the person should do, and what to refrain from.

The legal duties of the individual are a requirement established and guaranteed by law in regard to the individual's behaviour. They (as well as rights) are a necessary means by which legal impact on social relations is exercised. Neither right nor obligation exists alone. A person can enjoy any right only if it is respected and complied by others. In regard to the priority between rights and obligations, we prefer the former, since the internal logic of the construction of legal matter is mainly subordinated to subjective rights, which at the level of the abstract idea of law is, by its very definition, an active nodal centre of its own legal content.

S. P. Kotaleichuk characterises a legal duty that: (a) determines the extent of the individual's necessary behaviour in the form of retention or performance, (b) is conditioned by the needs of the existence and development of the subjects of law, (c) is a way of ensuring rights of the individual, (d) has a specific form of expression of legal responsibility ${ }^{1}$.

Therefore, we consider that work duties of an employee as a party to the employment relationship is a system of requirements established by legislative and local regulations in the field of work regarding certain behaviour of a worker during his/her performance under an employment contract, which is caused by the interests of the employer and guaranteed by possible legal coercion application by the State.

These responsibilities are a complex legal phenomenon that has a specific system.

\footnotetext{
1 Kotaleichuk, S. P. Theoretical and legal issues of underage persons' legal status in Ukraine and ensuring its realization as one of the main areas of police activity. Ph.D.'s thesis. National Academy of Internal Affairs. K., 2004. 235 p.
} 
A systematic approach to them should be discussed as the only area in the development of modern scientific knowledge. The main reason for this is that all the research carried out under this approach is in one way or another aimed at examining the specific characteristics of complex objects, that is, systems. Taking into account the basic principles of the general theory of systems, V. Kovalskyi argues that any object should be considered as conforming to the requirements of the system, which: contains interrelated and interacting structural elements (developed structure), has relative independence compared to other social objects (developed organization), internal integrity (developed core of the system), etc. ${ }^{1}$. A systematic approach to the legal duties of the worker enables to identify properly their place in the legal status of this subject of labour law.

The main specificities of a system distinguished by law study include: (a) integrity, that is, the primacy of the whole in relation to parts; (b) structural properties, that is, possible decomposition of the structure into components, establishment of relations between them; (c) non-additivity, that is, the fundamental impossibility of reducing the properties of the system to the sum of the properties of its components; (d) hierarchy, that is, each of its components is a subsystem of the wider global system ${ }^{2}$.

The system of employees' work duties includes:

1. General work duties for all, without exception, workers, no matter their legal form, ownership, sectoral affiliation, subordination and other characteristics of the employers requesting the work under the terms of an employment contract.

\footnotetext{
1 Kovalskyi, V. Security function of the State as a system. Yurydychna Ukraina, no. 11, 2003: 26-30.

2 Tzurikov, M. O. The system of transactions subject to public registration. Ph.D.'s thesis. Yaroslav Mudryi National Law University. Kh., 2011. 223 p.
} 
Article 3 of the Labour Code of Ukraine provides that the labour relationships of employees of all enterprises, institutions and organizations, regardless of ownership, type of activity and sectoral affiliation, as well as persons who work under an employment contract with natural persons, are regulated by the labour legislation. We advocate the perspective of L. Sirovatskaya that in modern labour law, the obligation to perform all work duties, and therefore the rules of law that provide them for, is formulated in the form of an obligation to observe labour discipline ${ }^{1}$. Therefore, Chapter X "Labour Discipline" of the Labour Code of Ukraine should include Article 139 "Worker Duties”. According to its provisions, employees are obliged to work honestly and fairly, in a timely and exact manner, to obey the owner or his authorized body, to observe labour and technological discipline, the requirements of the legal regulations on labour protection, to treat properly the property of the owner, with whom an employment contract is concluded.

Another approach is found in Art. 22 of the previously mentioned draft LC of Ukraine, which is included in Chapter 3 "The Subjects of Labour Relations" of Section 1 "General Terms." The article describes the basic duties of the worker:

- personal and honest performance of duties under an employment contract;

- observance of labour discipline and rules of internal labour order;

- fulfilment of the established labour standards and tasks of the employer;

- compliance with labour protection standards;

- proper custody of the employer's property;

- immediate notification of the employer about the threat to the life or health of workers, to their property;

1 Syrovatskaya, L. A. Responsibility for violation of labour legislation. M.: Yurid. lit., 1990.175 p. 
One-time gross breach of work duties as the ground for termination of the employment contract at the initiative of the employer

- notification of the employer about the reasons for absence from work;

- respect for the honour, dignity and other personal nonproprietary rights of the employer;

- compensation for the damage caused to the property of the employer by the acts of guilty while performing work duties;

- non-disclosure of State or trade secrets and other legally protected information.

2. Specific industrial work duties of workers engaged in work activities in enterprises, institutions and organizations that perform a certain type of economic activity in the field of tangible or intangible production.

Article 260 of the Economic Code of Ukraine ${ }^{1}$ interprets the term "sector" as the set of all production units performing mainly the same or similar economic activities. The field of material production includes sectors characterized by business activities aimed at creation, restoration or finding material benefits (goods, energy, natural resources) and continuation of production in turnover sector (sales) by transportation, storage, sorting and packing of goods, or other activity types. All other activities make the field of nonmaterial production (non-production sector).

General classification of economic sectors contributes a part of the uniform system of classification and encoding of technical-economic and statistical data used by economic entities and other participants of economic relations, as well as public bodies and local self-government authorities in the process of managing economic activity. In 1999 the United Nations Statistical Commission revised the International Standard Industrial Classification of All Economic Activities. It was initiated in connection with the rapid development

1 Economic Code of Ukraine (approved by Law of Ukraine no. 436-IV of 16 January 2003). Vidomosti Verkhovnoi Rady Ukrainy. 2003. No. 18-22. Art. 144. 
of technologies, especially in the field of information and telecommunication activities, the occurrence of new company specialization types, the division of labour, new conceptual approaches to differentiate professional and administrative services. Moreover, an increase in demand for more complete and meaningful information in some sectors of particular interest to international organizations in the implementation of international programs and public policies, such as environmental programs, the provision of drinking water, and human health etc. was considered.

In Ukraine, the Classification of Economic Activities, approved by the Order of the State Committee of Ukraine for Technical Regulation and Consumer Policy no. 457 of October 11, 2010 is in force ${ }^{1}$. Its objects are the types of economic activity of legal entities, separate subdivisions of the latter and individual entrepreneurs. Economic activity refers to the process of production of goods and services, carried out using certain resources, such as raw materials, equipment, labour, technological processes, etc. (section 2 of the Methodological provisions for determining the main type of economic activity of the enterprise, approved by the Order of the State Statistics Committee of Ukraine No. 607 of December 14, $2006^{2}$ ). Therefore, it should be emphasized that this activity is characterized by the production cost, process, outputs (goods and services) and is classified according to these factors.

Due to the fact that the enterprise can carry out not one, but several types of different economic activities, for their differentiation (grouping) the basic, secondary and auxiliary

1 Classification of Economic Activities DK 009:2010. (Approved by the Order of the State Committee of Ukraine for Technical Regulation and Consumer Policy No. 457 of 11 October 2010). http://search.ligazakon.ua/ 1_doc2.nsf/link1/FIN19567.html.

2 Order of the State Statistics Committee of Ukraine on approval ofmethodological provisions for determining the main type of economicactivity of the enterprise No. 607 of 14 December 2006. http://search.ligazakon.ua/ 1_doc2.nsf/link1/FIN25473.html. 
types of activity are established. The basic economic activity of the enterprise is the largest contribution to gross value added. A secondary type of economic activity is any other type of economic activity of the enterprise (except the basic one) for manufacturing products, goods or providing services. For example, international statistics usually studies a secondary type of economic activity, provided that the volume of such activity is more than $10 \%$ of the total indicators of activity of the enterprise, or at least $5 \%$ of the total activity in the corresponding type of economic activity in the region. Auxiliary economic activities are activities that are used by the enterprise for the purpose of providing its basic and secondary economic activities. An activity is auxiliary if it is: a) aimed at providing services or producing intermediate goods that are not part of the end products of the enterprise; b) associated with the current costs of the enterprise, that is, does not lead to the formation of fixed capital; c) aimed at servicing only the enterprise, that is, products, goods and services produced as a result of this activity are not marketed; d) typical of such enterprises. Auxiliary activities include management, accounting, transportation, warehousing, purchasing, sales, repairs, maintenance etc. The typical auxiliary activities are: own transportation services; storage, purchase of own production; accounting, administrative and economic activity. The classification of economic activities enables to conclude that each of these activities determines the specifics of legal activity in the corresponding field of economy, the specific of rules of law, as well as sectors of law.

The second level of the worker's legal duties is formed depending on the economic sector of their employment. This is reflected in the current legislation.

For example, according to the Article 56 of Law of Ukraine on Education ${ }^{1}$ pedagogical and scientific-pedagogical

1 Law of the USSR on Education No. 1060-XII of May 23, 1991, Vidomosti Verkhovnoi Rady of the USSR, no. 34, 1991. Art. 451. 
employees shall be required: to raise constantly their proficiency level, pedagogical skills and general culture; to provide conditions for mastering by pupils, apprentices, students, cadets, attendees, probationers, clinical interns, postgraduates of training programs at the level of compulsory requirements as per the contents, level and volume of education, to cause the development of abilities of children, pupils, students; by instructing and personal example to strengthen the respect to human morality principles: truth, justice, devotion, patriotism, humanism, kindness, tolerance, diligence, reasonableness and other virtues; to train children and young people to respect parents, women, elderly people, national traditions and customs, national, historical and cultural values of Ukraine, its government and social system, proper custody of historical, cultural and natural environment of the country; to prepare pupils and students to intelligent life in the sense of mutual understanding, peace, consent between all the nations, ethnic, national and religious groups; to observe pedagogical ethics, morality, to respect the dignity of a child, pupil, student; to protect children and young people from any form of physical or psychological violence, to prevent them from abusing alcohol, drugs and other bad habits. This approach is detailed in the special educational legislation. For example, Art. 58 of the Law of Ukraine "On Higher Education"1 requires academic teaching, academic, and teaching staff of higher educational institutions: to provide teaching at the high scientific-theoretical and methodological level of the disciplines of the corresponding educational program in the specialty, to carry out scientific activity (for academic teaching staff); to raise proficiency level, pedagogical skills and scientific qualification; to observe pedagogical ethics, morality, to respect the dignity of individuals, who

1 Law of Ukraine on Higher Education No. 1556-VII of 1 July 2014. Vidomosti Verkhovnoi Rady Ukrainy, no. 37-38, 2014. Art. 2004. 
study in higher educational institutions, to promote a love for Ukraine, to nurture them in the spirit of Ukrainian patriotism and respect for the Constitution of Ukraine and the national symbols of Ukraine; to develop autonomy, initiative, creativity in persons studying at higher education institutions; to adhere to the statute of higher education institution, laws, other legal regulations.

Article 10 of the Law of Ukraine on public service ${ }^{1}$ requires a public servant: to adhere to the Constitution and laws of Ukraine; to ensure efficient work and performance of tasks of public bodies within their competence; to prevent violations of human and citizen's rights and freedoms; to fulfil directly their duties, to execute timely and accurately decisions of public bodies or officials, orders and instructions of their managers; to preserve State secrets, information about citizens that they have become aware of in the course of performing public service duties, as well as other information which is not subject to disclosure under the law; to improve constantly his/her work arrangements and professional competence level; scrupulously perform his/her work duties, initiative and creativity. Moreover, the official must act within his/her authority. In case of receipt of an order that is contrary to the current legislation, a public servant is obliged to report immediately in writing to the official who has given the order, and in case of insisting on its execution, to report to the higher official.

3. Direct production and functional work duties are the duties assigned to the worker within the scope of the employment function by the employer in accordance with the employment contract concluded between them.

In each employment contract, its parties must specify a number of mandatory conditions, including the worker's job function. V. I. Shcherbyna concludes that the establishment

1 Law of Ukraine on Public service No. 3723-XII of 16 December 1993. Vidomosti Verkhovnoi Rady Ukrainy, no.52, 1993. Art. 490. 
of a worker's job function is a specification of the type of work with respect to his/her ability to work ${ }^{1}$. Determination of the job function is one of the main pillars of the concept of the employment contract. An important axiom, reflected in Art. 31 of the Labour Code of Ukraine, derives from it, in particular: "The owner or the body authorized by him has no right to request the worker's performance of work not stipulated in the employment contract." Otherwise, it is a forced labour, which according to Part 3 of Art. 43 of the Constitution of Ukraine is prohibited in our country.

V. V. Zhernakov and V. V. Eremenko advocate that the worker's job function should be considered in 2 basic statuses:

a) static, that is, the direct agreement of the parties to the employment contract on the nature of the work assigned to the employee, that is, a set of rights and obligations, agreed by the parties, to ensure the performance of work in a specific specialty, qualification or position. Since the conclusion of the employment contract, the labour function is formed, it exists, but its implementation will be carried out only in the course of the work, and may not begin at all, for example, if the employee does not start work;

b) dynamic, that is, the practical implementation of the established rights and obligations of the parties to ensure the performance of work in the course of labour relations ${ }^{2}$.

The consolidation of direct work duties of employees is in the local acts of the enterprise, in particular job descriptions. For example, according to the Standard job description of the chief media relations specialist (spokesperson), approved by the Order of the State Judicial Administration of Ukraine

1 Inshyn, M. I., Shcherbyna, V. I. (Eds.) Labour Law. Kh.: Nika Nova, 2012. $560 \mathrm{p}$.

2 Zhernakov, V. V., Eremenko, V. V. On the concept and content of the labour function. In Issues of firming social legality and the rule of law, strengthening the protection of the rights and legitimate interests of citizens in the context of restructuring socialistic society. K.: UMK VO. 1989: 61-65. 
No. $145^{1}$ of 6 November 2013, this specialist: coordinates the process of developing a communication strategy of the court in order to build effective relationships with the target audience of the court, to raise awareness of the court; analyses the target audience of the court, studies public opinion in order to solve communicative problems; ensures the development of information links between the court and court visitors, public authorities, enterprises, institutions and organizations, the media, promotes the formation of objective public opinion about the activities of the court; provides, within competence, preparing press releases, booklets, brochures, materials for press conferences, briefings, audio-visual presentations regarding court activities using computer technology, periodicals; provides information content of the court's website and analyses the effectiveness of this work; participates in preparing responses to media inquiries, materials aimed at refuting publications that contain inaccurate information, provides prompt response to inquiries and critical publications, reports; participates in preparing responses to citizens' appeals and considering requests for information, under the competence; studies materials and prepares draft texts of articles for publication in national, regional and local print media, as well as Internet resources and draft reports, certificates and other materials for speeches of court senior officials; coordinates interviews with judges and court staff with regards to court activities, arrangements of proceedings; prepares and submits to court senior officials a selection of information materials on the activities of the judiciary, express analysis (digests) of media materials; sends to the media press releases and copies of official documents, announcements of events and activities, programs and plans of the court with the prior consent

\footnotetext{
1 Order of the State Judicial Administration on approval of the standard job description of chief media relation specialist (spokesperson) No. 145 of 06 November 2013. http://dsa.court.gov.ua/dsa/ 14/4564563khgkjgg/.
} 
of the court senior officials; develops, in agreement with the court senior officials, action plans for prompt informing the public and the media regarding the consideration of high-profile court cases; participates in preparing and holding press conferences, briefings, in organizing thematic meetings on court activities; organizes methodological assistance to employees of the court staff on the application of information laws; accredits media representatives in court during court proceedings; monitors publications in the media on the activities of courts of general jurisdiction, comments on cases that have been considered in the courts; coordinates the media representatives' availability in court proceedings; analyses and summarizes the experience of the court's interaction with the public and the media; constantly increases the level of his/her professional competence; performs other instructions of the court management.

Therefore, the results of a comprehensive study in this subsection enable to make conclusions of significant theoretical and applied significance.

1. Characterizing labour law in general, not only the role of labour in public life, but also the significant specifics of this sector of law should be considered. It derives from the specificities of the object of legal regulation. Such an object is labour, namely the activity of a person who realizes his ability to work, that is labour.

In connection with the right to work, a person acquires the legal status of "worker". The latter is a natural person who works under an employment contract at an enterprise, institution or organization, regardless of their form of ownership and type of activity, or a natural person who, in accordance with the law, employs. It is the worker who is the bearer of labour, while labour relationships are the legal mediation of his/her labour activity.

2. Due to the lack of clarity and coherence in legal regulation, employees often find themselves in a certain legal 
vacuum. In turn, the social and legal insecurity of workers does not contribute to their being interested in the results of their work and the stability of labour relationship. Under modern conditions, the labour legislation of Ukraine faces a challenge of providing legal conditions required to achieve a balance of interests of the parties to the employment contract, economic growth, improving production efficiency and welfare. These goals can be achieved only in case of a high internal organization of the labour law system, as well as the integrity and consistency of the regulatory framework.

3. The will of the worker and the employer as participants in the employment relationship is realized by fulfilling their reciprocal rights and obligations. The establishment of these legal relations means the regulation of the worker's performance, on the one hand, and the employer, on the other.

Legal duties of a person, as well as rights, are necessary means by which legal influence on public relations is exerted.

Legal duties of a person, as well as rights, are necessary means of legal influence on public relations. Neither law nor duty exists without each other. A person can enjoy any right only if it is respected and adhered by others. With regards to the priority between rights and responsibilities, we prefer the former, because the internal logic of the legal matter construction is subordinated mainly to subjective rights, which at the level of the abstract idea of law, are by definition an active nodal centre of its own legal content.

Work duties of the worker as a party to the employment relationship is a system of requirements defined by legislative and local acts in the field of labour regarding specified behaviour of the employee in the course of the work under the employment contract, due to the interests of the employer and state-guaranteed coercive measures.

4. The system of work duties of employees includes: 
a) general work duties for all without exception, employees, regardless of the legal status, ownership, industry affiliation, subordination and other features of employers for whom they work under an employment contract;

b) special sectoral ones for workers employed in enterprises, institutions and organizations engaged in a particular type of economic activity in the sectors of tangible or intangible production;

c) direct production and functional ones for the worker within his/her employment function by the employer in accordance with the employment contract concluded between them.

\subsection{Definition and Significant Features of the Concept “Gross Breach of Work Duties”}

Though the current labour legislation of Ukraine actively uses the construction "of work duties", it does not provide its normative definition. Only paragraph 27 of the Resolution of the Plenum of the Supreme Court of Ukraine "On the practice of consideration of labour disputes by courts” No. 9 of November $6,1992{ }^{1}$ provides for that the court consideration of whether a breach of work duties is gross, should proceed on the basis of (a) the nature of the misdemeanour, (b) the circumstances under which it has been committed and (c) the damage that has been caused (could have been caused). Moreover, according to O. F. Cherdantsev, "definition is a form of concepts. They enable the legal study achieves conceptual accuracy ${ }^{2}$.

1 The Resolution of the Plenum of the Supreme Court of Ukraine on the practice of consideration of labour disputes by courts: No. 9 of 06 November 1992. Biuleten zakonodavstva i yuridicheskoi praktiki Ukrainy, no. 2, 2006. P. 154.

2 Cherdantsev, A. F. Logic-linguistic phenomena in jurisprudence. M.: Norma: INFRA-M, 2012. 320 p. 
One-time gross breach of work duties as the ground for termination of the employment contract at the initiative of the employer

The existence of legal definitions in general and their subsequent legalisation (from the Latin definitio "a concise logical definition that contains the most essential features of the denoted concept" ${ }^{1}$ ), is one of the features of legislative technique.

The expediency of legal definitions is promotion of the effective implementation of legal provisions, the implementation of the principles of legal certainty, the legal system stability. The principle of certainty, accuracy, clarity of the legal provision is a guarantee of the rule of law, because if each member of society understands his/her rights and responsibilities, he/she has a certain freedom of action and decision within the legal space.

According to Yu. A. Ushakova, to formulate a concept is to single out, to emphasize its most essential features, typical for all situations without exception, the essence that should be defined. Individual features should not be in the definition. Legal interpretation of the concept is a difficult task. While it is possible to realise clearly what it means, the definition will be unsuccessful. It is much easier to describe a specific concept of law than to interpret it universally ${ }^{2}$. V. B. Dresviankin argues that although the definition indicates the most common essential features of the subject and does not give an absolute idea of it, but it should not allow mixing of different concepts, and it should provoce logical thinking, allow to distinguish the subject under consideration, to clarify the meaning of a term already introduced into science, etc. ${ }^{3}$.

Therefore, before formulating the definition of the category "gross breach of work duties," the following

1 Apt, L. F. Legal definitions in the legislation. In Problems of legal technics. V. M. Baranova (Ed.). Nizhny Novgorod, 2000: 301-315.

2 Ushakova, Yu. A. Concept, content and forms of ownership. Ph.D.'s thesis. I. Franko Lviv National University. Lviv, 2011. 224 p.

3 Dresviankin, V. B. Gaps in the Russian labour law. Ph.D.'s thesis. Perm State University, Perm, 2001.163 p. 
essential features of this phenomenon should be identified and described.

1. This breach has caused or could have caused significant material or moral damage to the rights and interests of workers, employers or the State. The legal doctrine recognises damage as a set of negative effects of the offense. Therefore, any breach of the law causes one or another damage to public relations, because without it there is no offense. Damage is also a social phenomenon, i.e. the result of the offense against public relations, an effect of the breach of legally protected rights and interests of the State, organization or citizen ${ }^{1}$. The law regulation of any action or inaction as an offense is its recognition as socially dangerous. In reality, no such offenses exist that cause no harm to public relations. Otherwise, according to V. E. Sevriugin, the existence of an offense in state and public life would not cause any concern in society about the normal conditions of existence of the latter. Therefore, the State would not need a developed system of law enforcement institutions. The presence of an offense in the law-making mechanism is a sign of social damage that requires the occurrence of legal prohibitions ${ }^{2}$.

N. S. Malein argues that the social essence of damage is in a set of negative effects of the offense, which are: (a) breach of law and order, (b) disorganization of social relations and humiliation of individuals, (c) destruction of any good, value, subjective right, (d) restriction of their use, (e) unlawful interference with the freedom of conduct of other individuals ${ }^{3}$. In this case, it is a combination

\footnotetext{
1 Malein, N. S. Compensation for damage caused to a person. M.: Yurid. lit., $1965.228 \mathrm{p}$.

2 Sevriugin, V. E. The concept of an offense under administrative law. M.: Gosyurizdat, 1988. 216 p.

3 Malein, N. S. Delinquency: Concept, reasons, responsibility. M.: Yurid. lit., 1985. 192 p.
} 
of social and legal aspects, because every breach of social norms has a negative impact on social relations, i.e. causes social damage. As a result, unlawful actions breach both the rules of objective law and the subjective rights of the individual.

Gross breach of labour duties (as well as any other unlawful behaviour of the worker) causes or can cause damage both pecuniary and non-pecuniary. Such damage is significant. Gross breaches can be: (a) financial or tax breaches, (b) irrational disposal of property, (c) organization of significant material damage, etc. Moreover, an example of such a situation is a significant breach of the requirements of labour protection legislation by the head of the enterprise, institution or organization (suboffice, representative office, branch, other separate division), his deputies. In addition, this is natural, because Art. 4 of the Law of Ukraine "On labour protection" ${ }^{1}$ provides for that the key principle for the national policy in the field of labour protection is the priority of life and health of workers, full responsibility of the employer for creating proper, safe and healthy working conditions. Guarantees of safe and healthy working conditions, prevention of occupational diseases and occupational injuries, elimination of harmful production factors are the priority tasks of the State. The legal nature of labour protection is based on the recognition by the State of its obligation to protect the employee as the weakest party to the employment contract in order to preserve his/her life, health and ability to work.

D. O. Karpenko classifies legal and economic significance of labour protection. The legal one is provided by the legal regulations on labour protection that enable: a) to work according to abilities (taking into account working conditions, physiological features of working women, underage persons,

1 Law of Ukraine on labour protection No. 2694-XII: of 14.10.1992. Vidomosti Verkhovnoi Rady Ukrainy. 1992. No. 49. P. 668. 
persons with reduced working capacity, etc.); b) to determine the legal status of the worker, including the right to labour protection, guarantees and safety; c) to approve labour protection as an important element of the worker's labour relations with the employer (administration) in ensuring labour protection at the workplace. The economic significance is in the processes as follows: a) reduction of working time losses and savings of the social insurance fund, because proper labour protection ensures fewer occupational injuries, occupational diseases, etc.; b) increase in the productivity of workers, and the growth of production and economic development ${ }^{1}$.

The State requires the employer to create working conditions at the workplace in each structural unit in accordance with regulations, as well as to ensure compliance with the provisions of laws on workers' rights and protection of their labour. To this end, the employer ensures the functioning of the labour protection management system, namely:

- creates appropriate services and appoints officials who solve specific issues of labour protection, approves instructions on their duties, rights and responsibilities for the performance of their functions, as well as monitors their compliance; with the participation of the parties to the collective agreement, develops and implements comprehensive measures to achieve the standards established and to increase the existing level of labour protection;

- ensures the implementation of preventive measures required in accordance with changing circumstances;

- initiates advanced technologies and achievements of science and technology, means of mechanization and automation of production, ergonomics requirements, positive experience in labour protection, etc.;

1 Karpenko, D. O. Fundamentals of Labour Law. K.: A.S.K., 2003. 656 p. 
One-time gross breach of work duties as the ground for termination of the employment contract at the initiative of the employer

- provides proper maintenance of buildings and structures, production equipment and facilities, monitoring of their technical condition;

- ensures the elimination of the causes that lead to accidents, occupational diseases, and the implementation of preventive measures determined by the commissions following the investigation of the causes of these cases;

- organizes the audit of labour protection, laboratory studies of its conditions, assessment of the technical condition of production equipment and facilities, certification of workplaces for compliance with regulations on labour protection and accordingly, takes measures to eliminate production factors that are dangerous and harmful to health;

- develops and approves regulations, instructions, other acts on labour protection effective within the enterprise and establishes rules of performance and behaviour of workers in the territory of the enterprise, in production rooms, on construction sites, workplaces according to regulations on labour protection, provides workers free of charge with legal regulations and acts of the enterprise on labour protection;

- monitors the worker's compliance with technological processes, rules of handling machines, mechanisms, equipment and other means of production, the use of collective and individual protection, the work performance in accordance with the requirements of labour protection;

- organizes the promotion of safe labour methods and cooperation with workers in the field of labour protection;

- takes urgent measures of aid to victims, if necessary, involves professional rescue teams in case of accidents or emergencies at the enterprise.

Therefore, the concept of labour protection includes provisions: (a) on the rules of safety and industrial sanitation, (b) on the planning and organization of labour protection, (c) on labour protection of certain categories of workers, 
(d) governing the activities of public authorities and other subjects on supervision and control of labour protection.

For the breach of laws and other legal regulations on labour protection, for obstruction of the activities of officials of labour protection public supervision, as well as representatives of trade unions, their organizations and associations, the offenders are subject to disciplinary, administrative, material or criminal liability under the law. Although many of these provisions go beyond labour law, they are to ensure healthy and safe working conditions. For example: a) the civil law provisions are applied in determining material or moral liability in case of accidents at work; b) administrative - in establishing the procedure and conditions for the application of administrative penalties for a breach of labour protection rules; c) economic - in deciding on additional measures in the field of labour protection in individual types of economic activity; d) criminal - in establishing liability for a breach of norms on labour protection; e) constitutional - in the presence of the provisions in the Constitution of Ukraine as a regulation of direct action, guaranteeing the right to labour protection; f) environmental law - in defining the boundaries of anthropogenic impact on the environment ${ }^{1}$.

However, not every breach of the requirements of labour protection laws is gross. For example, such breach is the case of the head of the enterprise's disregard of the job certification under working conditions, i.e. a comprehensive assessment of factors of the production environment and labour process, related socio-economic factors that affect the health and efficiency of workers in the course of their performance. In accordance with the Procedure for attestation of workplaces under working conditions, approved by the Resolution of the Cabinet of Ministers of Ukraine No. 442 of 01 August

\footnotetext{
1 Obushenko, O. M. Legal regulation of labour protection in Ukraine. K.: Hi-Tech Press, 2014. 372 p.
} 
One-time gross breach of work duties as the ground for termination of the employment contract at the initiative of the employer

$1992^{1}$, and Methodical recommendations for attestation of workplaces under working conditions, approved by the Resolution of the Ministry of Labour of Ukraine No. 413 of 1 September $1992^{2}$, the main purpose of this measure is to regulate the relationship between the owner or his authorized body and workers regarding the exercise of the rights to healthy and safe working conditions, preferential pensions, benefits and compensation for work in adverse conditions, etc. The head of the enterprise or organization is in charge of timely and high-quality certification of jobs. Moreover, according to Part 1 of Art. 41 of the Code of Ukraine on Administrative Offenses ${ }^{3}$, a breach of the terms and procedure for certification of jobs under working conditions entails the imposition of fines on officials of enterprises, institutions and organizations, regardless of ownership and on citizens, who are business entities, from 30 to 100 nontaxable minimum incomes. According to Part 2 of Art. 41 of the Code of Administrative Offenses, a breach of the requirements of laws and other legal regulations on labour protection entails the imposition of fines on workers from 4 to 10 non-taxable minimum incomes and officials of enterprises, institutions and organizations, regardless of ownership and citizens, who are business entities, from 20 to 40 non-taxable minimum incomes of citizens.

2. Gross breach of work duties is an evaluative concept. The evaluative character of this concept challenges law enforcers, as evidenced by case law. S. M. Chernous argues that these challenges are due to the specific logical and legal

1 Resolution of the Cabinet of Ministers of Ukraine on the procedure for attestation of workplaces under working conditions No. 442 of 01 August 1992. http://zakon1.rada.gov.ua/laws/show/442-92-\%D0\%B.

2 Methodical recommendations for attestation of workplaces under working conditions (approved by Resolution of Ministry of Labour of Ukraine No. 41 of 01 September 1992). Ukr. Invest. Gas. 2008. No. 28.

3 Code of Ukraine on Administrative Offenses (approved by Law of Ukraine No. 8073-X of December 7, 1984). Vidomosti Verkhovnoi Rady USSR. No. 51. (Appendix). P. 1122. 
properties of the evaluative concepts of law and are the issues of their specification, interpretation, creation and application of provisions that contain them ${ }^{1}$. Definitely, the presence of evaluative concepts in the legal provision enables the subject of law application to resolve a situation, partly by their own discretion. However, the different levels of legal awareness of law enforcers, as well as the possibility of abuse of the right granted to them, require deciding on the limits of such discretion, so that the breach thereof enables the party concerned to have a chance to revoke the decision. At the same time, both the shortage of law and the use of evaluative concepts are exceptions to rule-making techniques, one of the reasons for which is in the impossibility (including subjective order) to predict the change of relations regulated by the normative act. When formulating evaluative concepts, this impossibility is recognized as an objective reality by the legislator, as a result, an attempt is made to cover suitable cases with indefinite or partially defined wording.

According to V. V. Lazarev, formulating a provision with evaluative features, the legislator means it to be influenced by a certain group of social relations, but due to the variety of relevant cases, he cannot describe them accurately ${ }^{2}$. Indeed, the phenomenon under study is not a gap of law, but a conscious assumption of the possibility for the performer to act proactively, taking into account the conditions, place and time. Therefore, the phenomenon under study is not a gap of law, but a conscious assumption of the possibility for the executer to be proactive, taking into account the conditions, place and time. A gap means a lack of a legal provision that regulates the current situation and requires the involvement

1 Chernous, S. M. Evaluative concepts in Labor Law of Ukraine. Ph.D.'s thesis. T. Shevchenko Kyiv National University. K., 2008. 212 p.

2 Lazarev, V. V. Application of Soviet law. Kazan: Kazan University, 1972. 200 p. 
of a provision of the same law sector (analogy of statute) or consideration of general legal principles (analogy of law).

M. I. Baru classifies evaluative concepts as a special way of expressing the will of the legislator for the convergence of law-making and law-application practice. The scholar identifies the following features of these categories: (a) not specified by the legislator or other competent authority, (b) specified in the process of law application, (c) enabling the enforcer of the law provision to freely assess the facts ${ }^{1}$.

According to O. V. Kobzeva, the functions of evaluative concepts are: (a) evaluative function, (b) functions inherent in the use of evaluative features as an independent method of legislative technique, such as the function of saving legislative material, substitution, compromise, dialecticalprognostic, consolidating and regulatory; (c) auxiliary functions of evaluative features, such as the function of initiating the activities of higher judicial bodies and linguistic ${ }^{2}$.

Evaluative terms play, so to speak, a "softening role" between the formal definition of legal regulation and evolving social relations.

First, S. M. Chernous formulated a definition of the construction "evaluative concept of labour law of Ukraine, interpreting this category as abstract idea of the properties, quality and value of phenomena, actions, persons, etc. that is used in the form of common words or phrases in the texts of labour law, characterizes any element of labour and closely associated relations and due to its logical features, is not specified fully and definitively in any legal regulation either by the legislator himself or by the subjects authorized by him, while finally it is specified by the

\footnotetext{
1 Baru, M. I. Evaluative concepts in labor legislation. Soviet State and Law, no. 7, 1970: 104-108.

2 Kobzeva, E. V. Evaluative features in criminal law. Saratov: SEI HVE Saratov State Acad. Law, 2004. 228 p.
} 
One-time gross breach of work duties as the ground for termination of the employment contract at the initiative of the employer

subject in the course of applying the rule, which contains it in each case, determined by objective and subjective factors, resulting in individual under-regulation of labour relations ${ }^{1}$.

O. A. Stepanova argues that evaluative concepts in labour law are characterized by logical, linguistic and legal features. The latter are: a) as a rule, the concept not specified in the legal regulation containing labour law provisions; b) the one specified in the course of law application, lawmaking or derived from scientific research; c) providing the subject of law-specifying activity with the opportunity to independently assess the facts of the case under mandatory compliance with the functional purpose of the regulatory requirement ${ }^{2}$.

According to New Explanatory Dictionary of the Ukrainian Language, word "hrubyi" [Engl. gross, rough] has different meanings, such as (a) large in volume and cross-section; thick; (b) hard, rigid, with an uneven surface; (c) poorly equipped, decorated; very simple, without elegance; (d) low, often unpleasant to the ear, sharp; (e) bad-mannered, impolite, indifferent, unkind, rude, brutal; which contains an insult; (e) not quite accurate, approximate; (g) which goes beyond the basic rules, deserves condemnation, offensive ${ }^{3}$. S. I. Ozhegov and N. Yu. Shvedova interpret this term as: a) insufficiently cultural, non-delicate, insensitive, unsubtle; b) insufficiently processed, unsophisticated, simple; c) hard, unsmooth, uneven; d) bout the voice, laughter, that is, deaf, low, unpleasant; e) preliminary, approximate, not developed in detail; f) about a mistake, breach of something, that is,

\footnotetext{
1 Chernous, S. M. Evaluative concepts in Labor Law of Ukraine. Ph.D.'s thesis. T. Shevchenko Kyiv National University. K., 2008. 212 p.

2 Stepanova, E. A. Evaluative concepts of Labor Law. Ph.D.'s thesis. Rostov State Un-ty. Rostov, 2005. 187 p.

3 New Explanatory Dictionary of the Ukrainian Language. - [У 3-х т. Т. 3: А-К; - вид. 2-ге, виправл.] / уклад.: В. В. Яременко, А. М. Сліпушко. К.: Вид-во Аконіт, 2008. - 926 с.
} 
serious, essential ${ }^{1}$. Therefore, the context of interest to the study is only in the variants, such as serious, important, which goes beyond the basic rules, deserves condemnation, offensive. However, these options lack clarity and certainty. Furthermore, the current labour legislation and law application lack clarity. Accordingly, the scope of the evaluative concept "gross breach of work duties" is not defined from the beginning.

Therefore, that the inclusion of evaluative concepts in the provisions of labour law should make the legal regulation of labour and associated relations in market conditions more flexible. However, to avoid the features of permissiveness due to this flexibility, it is necessary to outline the limits of the use of the relevant evaluative categories both in the legislation and in the practice of its application. The way to do this is specification, which in general is the provision of a particular object, phenomenon or process with maximum certainty and clarity. The main purpose of specification is to find a connection between the general legal rule and the circumstances of the actual reality. The interpreter should transfer the abstract content of legal provision to a more specific level, because after that the provision should become more meaningful. Specification is a special form that enables the abstract provision to become concrete, and therefore, its content becomes more accurate and clearer because of interpretation.

A significant contribution to the development of this phenomenon was made in the 70-80s of the twentieth century. M. M. Voplenko proposed to interpret the specification of law as a generic concept, which means the result of lawmaking or law application process, which reflects the maximum certainty and comprehensiveness of the meaning

1 Ozhegov, S. I. Explanatory dictionary of the Russian Language. (80000 words and phraseological expressions; 4th ed). S. I. Ozhegov, N. Yu. Shvedova (Eds.) M.: Ltd A TEMP, 2006. 944 p. 
of legal provisions, due to interpreting, detailing, clarifying or developing certain elements of provisions for the purpose of full and accurate legal regulation ${ }^{1}$.

The study of the epistemological essence and logical mechanism of law specification enables G. G. Shmeleva to conclude that the category under consideration is lawful activities of State and other authorized bodies, objectively determined, aimed at improving the accuracy of legal regulation, in relation to transferring the abstract content of legal provisions to more specific level by determination, the results thereof are recorded in legal regulations ${ }^{2}$.

The specification of legal provisions is similar to their interpretation. According to Yu. L. Vlasov, the essence of legal specification is the initiation of the law, which does not go beyond the content of the legal provision but contains a new element of detailing the regulation of social relations, not conveyed in this legal provision. The interpretation only clarifies, reveals, substantiates parts of the content of the legal provision, but no new elements of legal regulation are established ${ }^{3}$.

S. V. Pryima advocates the idea of distinguishing these concepts, that is, the interpretation of legal provisions differs from their specification, because: (a) the interpretation is based on cognition, intellectual activity, while the core of specification is the narrowing of the scope of considering an individual rule, phenomenon, process; (b) the purpose of the interpretation is to reveal the content of the legal provision, while the specification is to increase its clarity and certainty; (c) the interpretation is broader in scope than the specification, since it includes not only description in details,

1 Voplenko, N. N. Official interpretation of provisions of law. M.: Yurid. lit., 1976. $118 \mathrm{p}$.

2 Shmeleva, G. G. Specification of legal provisions in legal regulation. Lvov: Higher school, 1988. 104 p.

3 Vlasov, Yu. L. Problems of interpretation of provisions law. Extended abstract of Ph.D.'s thesis. ISL NAS of Ukraine. K., 2000. 17 p. 
clarification of the legal provision, but also determination of the historical and social conditions of the legal regulation adoption, the purpose of its publication, functions and place in the legal system, etc., while the specification is only one of the means of interpreting legal provision; (d) the interpretation is an activity required for any legal regulation, the specification in general is also applied, but not always ${ }^{1}$.

Therefore, in case of gross breach of work duties, the worker's wrongful acts cause or may cause significant pecuniary and non-pecuniary damage to the rights and interests of employees, the employer or the State.

In order to specify the evaluative concept under study, and therefore to facilitate the law application, it should be legislated that gross breach of work duties occurs in the cases when pecuniary damage caused by illegal behaviour of the worker exceeds a certain minimum legally fixed (for example, 10 minimum wages), and non-pecuniary one if the violation of rights and interests not only led to moral suffering, loss of normal life connections and for additional efforts to organize the life of an individual employee, but also caused a deterioration of the image and credibility of an individual enterprise, institution or organization and the relevant service in general.

While the content of pecuniary damage is generally clear, the matter of non-pecuniary will be revealed on the example of public service. As is known, the behaviour of public servants shall meet the expectations of the public and ensure the confidence of society and citizens in the public service, promote the realization of human and civil rights and freedoms proclaimed by the Constitution and laws of Ukraine. The official should promote the positive authority of public establishments and public service bodies, cherish

1 Pryima, S. V. Principles of interpretation of provisions of law. Ph.D.'s thesis: Yaroslav Mudryi National Law University. Kh., 2010. 194 p. 
his/her name and status. In this regard, O. V. Petryshyn emphasizes that the main difference between civil and militarized public service is the use of civilian (non-military) management methods, based mainly on authority and not on coercion. Public servants are not military officers, but civilians, are not in military or militarised service with all its attributes ${ }^{1}$. In the course of performing official duties, these persons are obliged to strictly adhere to the requirements of the law and generally accepted ethical rules of conduct, to be polite in relations with citizens, managers, colleagues and subordinates.

According to Chapter VI of the Law of Ukraine "On Prevention of Corruption" ${ }^{2}$, ethical conduct rules of public servants should cover certain guidelines such as:

a) priority of interests, that is, representing the State or territorial community, these persons shall act solely in their interests;

b) political neutrality, that is, in the performance of their official duties they are obliged to adhere to political neutrality, to avoid in any form the demonstration of their own political beliefs or views, not to use official powers in the interests of political parties or their branches or individual politicians;

c) impartiality, that is, to act impartially, regardless of private interests, personal attitude to any person, their political, ideological, religious or other personal views or beliefs;

d) competence and efficiency, that is, conscientiously, competently, timely, effectively and responsibly perform official duties and professional duties, decisions and instructions of bodies and persons to whom they are

1 Petrishin, A. V. Civil service. Historical and theoretical preconditions, comparative legal and logical-conceptual analysis. Kharkov: Fakt, 1998. 168 p.

2 Law of Ukraine on prevention of corruption No. 1700-VII of 14 October 2014. Ofitsiinyi visnyk Ukrainy, no. 87, 2014. Art. 2474. 
subordinated, accountable or controlled, to prevent abuse, inefficient use of public and communal property;

e) non-disclosure of information, that is, not to disclose and not to use in any other way confidential and restricted information, which became known to them in connection with the performance of their official duties and professional duties, except as provided by law;

f) refraining from executing unlawful decisions or instructions, that is, notwithstanding private interests, to refrain from executing decisions or instructions of management, if they contradict the law, independently assess their legality and possible damage that may be caused in case of execution of such decisions or instructions.

The specification of the evaluative concept of "gross breach of work duties" directly in the local acts of the enterprise or in the employment contract does not contradict the current labour legislation. The contractual form of the latter is usually used for this purpose. According to O. M. Duiunova, the occurrence of the contract is due to the country's transition from a planned to a market economy. Freedom of entrepreneurship is associated with free choice of workers, with greater freedom of action for the employer in determining the terms of employment, which entails the need to expand the contractual framework in labour relationship legal regulation. The contract seems to be opposed to the employment agreement, which is attributed to such shortcomings as the narrow limitation of job responsibilities, their strict regulation, due to current job descriptions, qualification directories and other local acts ${ }^{1}$. I. Yusypiuk argues that the contractual form of employment is designed to ensure the combination of interests of the employee, the owner of the property of the enterprise and the workforce, i.e. it is an important element of social

1 Duiunova, O. M. Labor agreements under the labor legislation of Ukraine. Ph.D.'s thesis. T. Shevchenko Kyiv National University. K., 2003. 194 p. 
partnership. Under the strict market laws, the initiation of a contract employment system allows the employer to relatively easily get rid of unpromising and dishonest, in his/her view, workers. The contract has become especially popular with employers of all forms of ownership, as it empowers them to manoeuvre labour resources freely ${ }^{1}$.

According to the Standard form of the contract with the head of the state-owned enterprise, approved by the Resolution of the Cabinet of Ministers of Ukraine No. 597 of 2 August $1995^{2}$, the head may be dismissed, and the contract is terminated at the initiative of the Property Management Authority before its termination, in cases:

- one-time gross breach of the law or obligations under the contract by the manager, resulting in significant negative consequences for the company (incurred losses, paid fines, etc.);

- non-performance of obligations to the budget or the Pension Fund regarding the payment of taxes, fees and mandatory payments, insurance premiums, as well as regarding the payment of wages to employees or noncompliance with the schedule of repayment of wage arrears, by the enterprise; non-submission of the annual (with a quarterly breakdown) financial plan of the enterprise for approval or adjustment to the Property Management Body, breach of the procedure for expenditures by business entities of the public economic sector in case of non-approval (disagreement) of the annual financial plan;

- non-payment of restructured tax arrears within 3 months due to the fault of the head;

- breach of the procedure for settlements in foreign currency;

1 Yusypiuk, I. Contract is stylish. But is it effective? Pravovyi Tyzhden, no. 50 (71), 2007: 6.

2 Resolution of the Cabinet of Ministers of Ukraine regarding Standard form of the contract with the head of the state-owned enterprise No. 597 of 2 August 1995. Ukr. Invest. Gas, no. 50, 2007: 286. 
- permitting of growth of overdue accounts payable;

- when in 3 reporting quarters during the calendar year there is an increase in receivables of the enterprise, which in the general result of these quarters is not accompanied by a corresponding increase in sales of its products (goods, works, services);

- failure to submit quarterly and annual financial statements, as well as quarterly and annual reports on the enterprise's financial plan implementation together with an explanatory note on the performance;

- breach of legislation in the use of finances of the enterprise, including the public procurement of goods, works and services.

These grounds for termination of contact should be considered as cases of gross breach of the law or responsibilities under the contract by the head of the enterprise.

A slightly different but fundamentally similar approach is provided for in the Contract with the Chairman of the Board of the Open Joint Stock Company ${ }^{1}$, under paragraph 6.3 of which the manager may be dismissed, and the contract with him/her may be terminated at the initiative of the Supreme Body (privatization body) before its expiration, if the head (a) has committed one-time gross breach of the law or responsibilities under the contract, which had negative effects for the company (damages, fines, damaged authority of the company, etc.), (b) conceals information about the unfinished construction objects to be privatized.

The subjects committed gross breach of work duties are special categories of employees established by law. According to the current labour legislation of Ukraine (para. 1, part 1 of Article 41 of the Labour Code), the

1 Letter from the State Property Fund of Ukraine regarding Contracts with the Chairman of the Board of the Open Joint Stock Company No. 10-17-11495 of 05 November 1999. Biul. pro pryvatyzatsiu, no. 1, 2000: 250. 
subjects of one-time gross breach of work duties are the head of the enterprise, institution, organization of all forms of ownership (sub-office, representative office, branch, other separate division), his deputies, chief accountant, his deputies, officials of the revenue and duties bodies nominated for special ranks, and officials of central executive bodies implementing national policy in public financial control and price control. Similarly, para. 1, part 2 of Art. 92 of the Draft LC of Ukraine (registration No. 1658, text of December 27, 2014) provides for that the employment contract may be terminated at the initiative of the employer in case of one-time gross breach of work duties by the head of the entity (sub-office, representative office, branch, other separate division), his deputy, chief engineer, chief accountant, his deputy, as well as officials of the Customs Service of Ukraine and the State Fiscal Service, nominated for special ranks, and officials of central executive bodies implementing national policy in public financial control and price control.

Another perspective, that is, the recognition of onetime gross breach of work duties in all cases of a worker's misconduct, entailing possible discharge at the initiative of the employer, is reflected in the labour legislation of some foreign countries.

For example, according to the Labour Code of Turkmenistan ${ }^{1}$, the grounds for dismissal of an employee are his/her one-time gross breach of work duties (Article 42) and one-time gross breach of work duties by the head of the enterprise (unit), his deputies and employees disciplinary responsible as provided by the statutes (Article 43). However, the Code does not contain a specific list of cases when these grounds are used. According to Art. 81 of the Labour Code

\footnotetext{
1 Labour Code of Turkmenistan (approved by Law of Turkmenistan No. 30-IV of 18 April 2009). Vedom. Medzhlisa Turkmenistana, no. 2 (996), Part 4, 2009. Art. 30.
} 
of the $\mathrm{RF}^{1}$, an individual ground for discharge is one-time gross breach of work duties by the worker of the head of the organisation (sub-office, representative office), his deputies. In regard to the employee: (a) truancy, i.e. his/her absence from the work without reasonable excuse throughout the working day (shift) regardless of its duration, as well as absence from work without reasonable excuse for a period longer than four consequent hours during a working day (shift); (b) appearing on working place in a state of alcoholic, narcotic or other intoxication; (c) disclosure of a secret, protected by law, that has been learned by an employee because of his job functions, including personal data on another worker; (d) commission of a theft (including minor theft), embezzlement or intentional damage or destruction of property, established as such under court verdict, entered in force, or decision of a judge, body, official, authorized to consider cases of administrative offenses; (e) worker's breach of labour protection regulations established by the commission or the commissioner for labour protection if it has coursed disastrous consequences or could certainly lead to these consequences.

It should be noted that the Transnistrian Moldavian Republic has completely reproduced this legal provision in its LC.

According to the Labour Code of the Kyrgyz Republic ${ }^{2}$ that distinguishes one-time gross breaches by the head of the organization (sub-office, representative office), his deputies of their work duties, one-time gross breaches by employees of their work duties are: (a) truancy, i.e. the absence from the work without reasonable excuse

1 Labour Code of the Russian Federation (approved by Law of the RF No. 197-FZ of 30 December 2001). Collection of RF legislation, no. 1, Part 1, 2002. Art. 3.

2 Labour Code of the Kyrgyz Republic (approved by Law the Kyrgyz Republic No. 106 of 04 August 2004. Vedom. Zhogorku Kenesha Kyrgyzskoy Resp., no. 4, 2006. Art. 392. 
throughout the working day for a period longer than three consequent hours; (b) appearing on working place in a state of alcoholic, narcotic or other intoxication; (c) commission of an intentional damage or theft of property of the organisation; (d) breach of labour protection regulations if it has coursed disastrous consequences, including injuries and accidents; (e) disclosure of State, job, commercial or other secret, protected by law, that has been learned by him her because of his job functions, if its non-disclosure is provided by employment contract.

A legislative and scientific-theoretical distinction into (a) one-time gross breach of work duties by employees in general and (b) individual categories of employees (the head of the organization (sub-office, representative office), his deputies, officials who are subject to the requirements of disciplinary statutes, etc.), recognizes all cases of one-time commission of unlawful behaviour by these persons, which can entail dismissal at the initiative of the employer as gross breach of work duties by employees.

However, this scientific and regulatory approach is inappropriate, because it implies a substitution of categories, a basis for confusion and, in the end, law application suffers. More logical and balanced further use of two legal categories (both in labour law study and in labour law) should be as follows: (a) one-time substantive breach of work duties, in relation to employees in general and (b) one-time gross breach of work duties, in relation to special categories of employees.

According to Art. 121 of the Labour Code of the Republic of Armenia ${ }^{1}$, the employer shall have the right to terminate the employment contract with the employee, if he/she has at least once committed a gross disciplinary breach. Art. 221 of the

1 Labour Code of the Kyrgyz Republic (approved by Law the Kyrgyz Republic No. 106 of 04 August 2004. Vedom. Zhogorku Kenesha Kyrgyzskoy Resp., no. 4, 2006. Art. 392. 
Code provides for that such breaches are: (a) committing acts that violate the constitutional rights of citizens; (b) disclosure of state, official, commercial or technological secrets or informing to a competing organization thereon; (c) the abuse of official position for the purpose of obtaining illicit income for oneself and others, for other motives, as well as the abuse of discretion; (d) violation of equality between women and men or sexual harassment of employees, subordinates or beneficiaries; (e) appearing on working place under the influence of alcoholic beverages, narcotic or psychotropic substances; (f) failure to come to work throughout the entire working day (shift) with no good reason; (g) rejection from mandatory medical examination. However, the labour law of the country under consideration does not contain any special provisions enabling to discharge certain categories of workers in case of a gross breach of work duties.

The issue of subjects of discharge in case of one-time gross breach of work duties will be under focus in Section 3.1 of the monograph.

Gross breach of work duties is a disciplinary offense. One of the most important social characteristics of a person is his/her behaviour. Legal behaviour is social behaviour (action or inaction) of a consciously volitional nature, which is regulated by law and has legal effects. Generally, it has 2 main forms, such as lawful behaviour (socially useful, in compliance with legal requirements) and unlawful (socially harmful, contrary to law).

The only appropriate human behaviour is lawful behaviour, which is an activity conditioned by cultural and moral views and human life experience in the field of social action of law and based on the conscious performance of the tasks and requirements of the latter. Such behaviour is socially useful because it is aimed at satisfying state and legal, public and personal interests. Legitimate behaviour is especially valuable for the law, because it is human being, 
his/her rights and freedoms that are the highest social value. The value of such behaviour for the State can be defined as the expected activity of citizens, directed rightly and usefully, while generally the behaviour is planned and expected. In other words, such behaviour is easier to control by the State.

Legal regulation is aimed at ensuring the implementation of subjective rights and legal duties in the forms of performance, use, observance and application. The lawful behaviour of the subjects, as a result of such realization, is a necessary condition for the normal functioning of any society. S. A. Kapitanska argues that lawful human behaviours does not require constantly increasing punishment, but provisions that follow from the already existing social relations, and therefore will be broken with the least probability. Then society itself will realize the high value of lawful behaviour and adhere to it as an important factor of stability ${ }^{1}$.

The consideration of lawful behaviour is the basis for the legislator to establish provisions in Art. 139 of the Labour Code of Ukraine as follows: "Employees shall perform his/ her work duties in good faith, timely and accurately comply with the instructions of the owner or his authorized body, comply with labour and technological discipline, labour protection regulations, take due care of the property of the employer under the employment contract”.

Employee responsibilities regarding employment discipline are set out more broadly in the statutes and regulations on discipline. In particular, in accordance with Art. 7 of the Disciplinary Statute of the bodies of internal affairs of Ukraine $^{2}$, official discipline is based on high

1 Kapitanska, S. A. Legitimate inactivity as a form of legal conduct. Ph.D.'s thesis. National Academy of Internal Affairs. K., 2005. 220 p.

2 Law of Ukraine on the Disciplinary Statute of the bodies of Internal Affairs of Ukraine No. 3460-IV of 22 February 2006. Vidomosti Verkhovnoi Rady Ukrainy, no. 29. 2006. Art. 245. 
consciousness and requires each person of the rank and file and commanders:

- to observe the laws, to steadily fulfil requirements of the Oaths of a police officer, statutes and orders of commanders;

- to protect and defend from unlawful encroachments on life, health, rights and freedoms of citizens, property, the environment, the interests of society and the State;

- to respect human dignity, show concern for citizens and be ready to help them at any time;

- to adhere to the provisions of professional ethics and official conduct;

- to keep the state secret;

- to be honest, objective and independent from any influence of citizens, their associations and other legal entities in the course of official performance;

- to endure all difficulties and hardships associated with the service;

- to improve constantly their professional and cultural level;

- to assist superiors in strengthening official discipline, ensuring legality and statutory order;

- to show respect to colleagues and other citizens, to be polite, to follow the internal rules, the authorised uniform for wear, greetings and etiquette;

- to behave with dignity and honour during off-duty hours, to be a model in the observance of public order, to stop unlawful actions of persons who commit them;

- to protect and maintain in proper condition the transferred firearms, special means, property and equipment.

Thus, in labour law, contrasting other sectors of law, the obligation to comply with all work duties, and therefore, the legal provision that establishes them, is explicitly stated in the form of a direct obligation to adhere to labour discipline. 
The legal nature of labour discipline is twofold; whereas it provides for mutual obligations of the parties to the employment contract: (a) the employer is obliged to create the working conditions necessary for the employee to perform his/her job function most effectively, and (b) the employee is obliged to strictly comply with the rules of conduct established by local regulations and agreements of the parties.

The determination of the essence of labour discipline requires to consider that it is an integral part of labour relations, the subjects of which are the employee and the employer with mutual rights and responsibilities. The analysis of the powers of the employee enables Yu. M. Poletaev to argue that similar to the administration, the employee is an active participant in the formation of lawful order at the enterprise, having only a few other legal means. It is clear that the exercise of his/her power, both an independent right to claim when the administration performs its duties properly and requirements that come into force in the event of non-performance by its representatives, is not only the satisfaction of a particular employee' interests. The daily exercise of these powers forms the legal order in the organization and returns it to the framework of labour legislation in cases when individual managers of the labour process go beyond these limits ${ }^{1}$.

Breach of work duties, and hence labour discipline, by an employee is unlawful conduct. The generalized basis of responsibility in labour law is the unity of its factual and legal preconditions, without which it cannot be realized. The legal ground is the provision of law, which indicates the level of legal liability for the offense and establishes the possibility of its occurrence. The factual ground is an offense, without which the occurrence of a legal relationship of liability is impossible.

1 Poletaev, Yu. N. Law and responsibility in Labour Law. M.: Prospekt, 2001. 184 p. 
One-time gross breach of work duties as the ground for termination of the employment contract at the initiative of the employer

F. F. Skakun interprets the offense as a socially dangerous or harmful illegal (unlawful) guilty act (action or inaction) of a tort person, which entails legal liability ${ }^{1}$. K. L. Buhaichuk classifies the main features of this negative phenomenon into: (a) unlawful, that is, contrary to the law, a violation of prohibitions provided for by laws and regulations, failure to comply with the obligations arising from the legal regulation, the act of application of the provisions of the law or the contract concluded on the basis of law; (b) a socially dangerous or socially harmful phenomenon; (c) reflected in behaviour, in unlawful action or inaction; (d) conscious and volitional, i.e. the moment of the offense depends on the will and consciousness of the person; (e) guilty, i.e. it is an act that contains guilt and expresses the negative internal attitude of the offender to the interests of others; (e) punishable, that is, entails the application of remedial or legal liability to the offender ${ }^{2}$.

Labour discipline has a dual nature and involves mutual obligations of the parties to the employment contract: (a) the employer is obliged to create the working conditions necessary for the employee to perform the job function most effectively, and (b) the employee is obliged to strictly follow the rules of conduct, established by legislative regulations, local provisions and agreements of the parties. It is a complex, comprehensive phenomenon, as it is not limited to the proper performance of any single duty.

A disciplinary misdemeanour is a guilty, unlawful, but excluding criminal liability, failure to perform work duties, failure to exercise or exceeding the powers that ensure the labour process, by a person who is in an employment relationship with a particular organization.

\footnotetext{
1 Skakun, O. F. Theory of state and law. Kharkov: Konsum, 2000. 704 p.

2 Bugaichuk, K. L. Administrative misdemeanour: Essence and organizational-legal actions of their prevention. Ph.D.'s thesis. National University of Internal Affairs. Kh., 2002. 243 p.
} 
The analysis of the different approaches (of both scientists and lawmakers) to the definition of "disciplinary misconduct", enables V. S. Kovryhin to identify its main features as follows: (a) the subject of this misconduct can only be an employee who is in an employment relationship with a particular employer; (b) this misdemeanour is in case of the breach of work duties by employees as established by labour law, collective and employment agreements; (c) its forms may be non-performance or improper performance of work duties and excess of power; (d) the disciplinary misdemeanour is unlawful; (e) it occurs when the employee commits guilty acts; (e) its commission entails the application of disciplinary actions, provided for by labour law ${ }^{1}$. Gross breach of work duties meets all these characteristics, so it is a disciplinary offense.

5. Gross breach of work duties may entail a dismissal of the employee at the initiative of the employer. The employee's failure to perform his/her job descriptions entails legal liability. According to O. S. Yoffe and M. D. Shargorodskiy, liability should be specific negative effects for the subject compared to his/her status before the offense ${ }^{2}$. In its direct manifestation, legal liability is a certain deprivation, that is, the offender has negative effects of a personal, property or organizational nature. S. M. Bratus interprets the essence of legal liability as the implementation of sanctions of a law provision, as the same duty, but performed compulsorily, if the person (citizen or organization) subject to perform this duty, does not do it voluntarily ${ }^{3}$.

The concept of liability in law is a systemic regulatory entity that has the appropriate goals, objectives, structure and scope. The subject of its regulation is a certain kind

1 Kovryhin, V. S. Disciplinary liability in Labour Law. Ph.D.'s thesis. T. Shevchenko Kyiv National University. K., 2012. 221 p.

2 Yoffe, O. S. and Shargorodskii, M. D. Issues of the theory of law. M.: Yurid. lit., 1961. $421 \mathrm{p}$.

3 Bratus, S. N. Legal liability and legality. M.: Yurid. Lit., 1976. 311 p. 
of protective public relations that arise due to committing an offense. It is a relationship between a State and a person who has committed an offense, the content of which is his/her failure or improper performance of a special duty imposed in accordance with the law. V. I. Popov formulates rather appropriately the ratio of legal relations and liability in law. The jurist emphasizes that labour relations and the legal liability of workers are ancillary: they have a certain legal relationship, embodied through the rights and responsibilities that are common components of both phenomena. Nevertheless, these components perform different functions, that is, differ in levels of rights and responsibilities. The legal status of the subject undergoes a quantitative change. The altered ratio of rights and responsibilities within or outside the employment relationship is a qualitatively new legal relationship with a special function. The latter is based on public coercion, which means that the occurrence and development ofliability is associated with the implementation of the sanction of legal provision, which is not true about the employment relationship ${ }^{1}$.

Disciplinary liability is the worker's obligation to be punished for unlawful non-performance or improper performance of work duties imposed on him, provided by the labour law provisions. According to I. I. Veremeenko, the sanction is an element of the legal provision established by the State for its protection, specifying the measures of public coercion applied to the person for breach of this provision for the purpose of correction and re-education him/her (as well as other persons) in spirit of compliance with the law, respect for the rules of communal life, as well as to prevent new offenses ${ }^{2}$.

1 Popov, V. I. Legal liability of workers and employees under Soviet Labour Law. Extended abstract of Ph.D.'s thesis. Sverdlovsk Law Institute. Sverdlovsk, 1974. $20 \mathrm{p}$.

2 Veremeenko, I. I. Administrative and legal actions. M.: Yurid. lit., 1975. $180 \mathrm{p}$. 
Article 147 of the Labour Code of Ukraine provides for that breach of labour discipline entails application of only one of punishment measures to the employee by the employer, such as reprimand or dismissal. In case of gross breach of work duties by an employee that causes or may cause significant pecuniary and non-pecuniary damage to the rights and interests of employees, the employer or the State, the offender may be subject to a labour sanction such as dismissal (Art. 41 of the LC).

The legal constructions of "dismissal of an employee” and "termination of the employment contract" are similar in the content and scope. V. M. Tolkunova argues that since the termination of the employment contract and dismissal have a single basis and procedure, they are synonymous, although the termination applies to the employment contract, and the dismissal concerns the employee ${ }^{1}$.

Dismissal is an extreme disciplinary measure when the perpetrator is subjected to a personal and property oppressive measure. From the moment of termination of employment, a person loses the status of “employee," is deprived not only of legal responsibilities but also of numerous labour rights, including the right to: (a) remuneration, not less than the statutory minimum wage, and its timely payment in full; (b) appropriate working and living conditions related to the worker's performance of his/her duties under the employment contract; (c) guarantees and compensations provided for by State legal regulations in the field of labour; (d) a leave, etc. According to Art. 47 the LC of Ukraine, on the day of dismissal, the owner or his/her authorized body is required to issue the employee a duly executed employment record book and make a settlement with him/her within time limits as provided for in Art. 116 of the Code. The settlement is the payment all due amounts, salaries and compensation for unused leave, severance pay, to the employee, if it is

1 Tolkunova, V. N. Labour Law. M.: Prospect, 2004. - 651 p. 
provided by Art. 44 of the LC or other regulations, etc. It is due on the day of discharge. If the person did not work on the day of dismissal, these amounts must be paid no later than the day next after the submission of a claim for payment by a person dismissed. Before paying the amounts accrued upon dismissal, the employer is required to notify the employee in writing.

This type of disciplinary action is applied only when other measures have been exhausted and have not had a positive effect or if the committed disciplinary offense is incompatible with the employee's continued tenure.

Moreover, dismissal is a legal fact, consisting of a set of concerted actions of the employer and employee, resulting in termination of employment relationship between them, settlement of mutual labour rights and responsibilities, the socio-legal status change of the latter, who ceases to be an employee of this employer, and the employer loses disciplinary power over him/her. Dismissal is carried out within a space limited by the enterprise, institution or organization and at the time, from the first day of the dismissal procedure till the last working day of the person. According to P. D. Pylypenko, the concept of “dismissal” corresponds to the technical registration of the procedure for termination of employment ${ }^{1}$. According to Art. 47 of the LC of Ukraine, the dismissal of a person on the initiative of the owner or his authorized body, the latter is obliged to issue a copy of the dismissal order on the same day. In other cases, a copy of the order is issued at the request of the employee. Therefore, gross breach of work duties is the unlawful conduct of the categories of workers, established by law, as a result of which other workers of the enterprise, institution, organization, the employer or the State have suffered or could have suffered substantial pecuniary and non-pecuniary damage; such conduct may entail the application, in the prescribed

1 Pylypenko, P. D. Labour Law of Ukraine. L.: Vilna Ukraina, 1996. 159 p. 
manner, of disciplinary action, including dismissal, to the guilty person.

Therefore, a comprehensive study in this section of the monograph enables to make conclusions of significant theoretical and practical significance.

1. While the current labour legislation actively uses the concept of "gross breach of labour duties", it does not contain a statutory definition. Only paragraph 27 of the Resolution of the Plenum of the Supreme Court of Ukraine "On the practice of consideration of labour disputes by courts” No. 9 of November 6, 1992 provides for the prescription as follows: the court consideration of whether a breach of work duties is gross, should proceed on the basis of (a) the nature of the misdemeanour, (b) the circumstances under which it has been committed and (c) the damage that has been caused (could have been caused). The existence of legal definitions in general and their further legal consolidation is one of the signs of proper legislative technique. The expediency of legal definitions is to promote the effective implementation of legal requirements, ensuring the principles of legal certainty, the legal system stability. The principle of certainty, accuracy, clarity of a legal provision is a guarantee of the rule of law. After all, if every member of society understands his rights and responsibilities, he/she has a certain freedom of action and decision within the legal framework.

2. The essential features of the category "gross breach of work duties” as a labour law phenomenon include:

- this breach has caused or could cause substantial pecuniary and non-pecuniary damage to the rights or interests of employees, employers or the State;

- this category is an evaluative concept;

- subjects of this breach are special categories of employees defined by law;

- this breach is a disciplinary misdemeanour; 
- breach can entail dismissal of the employee at the initiative of the employer.

3. Gross breach of work duties is the unlawful conduct of categories of workers defined by law, as a result of which other workers of the enterprise, institution, organization, the employer or the State have suffered or could have suffered substantial pecuniary and non-pecuniary damage; and which may entail the application, in the prescribed manner, of disciplinary action, including dismissal, to the guilty person.

We argue that scientific and regulatory approaches to a legislative and scientific-theoretical distinction into onetime gross breach of work duties by employees in general and individual categories of workers (the head of the organization (sub-office, representative office), his deputies, officials who are subject to the requirements of disciplinary statutes, etc.), as well as to recognition of all cases of one-time commission of unlawful behaviour by these persons, which can entail dismissal at the initiative of the employer, as gross breach of work duties by workers, are inappropriate. This due to the fact that it implies a substitution of categories, a basis for confusion and, in the end, law application suffers. More logical and balanced further use of two legal categories (both in labour law study and in labour law) should be as follows: (a) one-time substantive breach of work duties, in relation to employees in general and (b) one-time gross breach of work duties, in relation to special categories of workers.

4. The inclusion of evaluative concepts in the provisions of labour law should make the legal regulation of labour and associated relations in market conditions more flexible. However, to avoid the features of permissiveness due to this flexibility, it is necessary to outline the limits of the use of the relevant evaluative categories both in the legislation and in the practice of its application. The way to do this is specification, which in general is the provision 
of a particular object, phenomenon or process with maximum certainty and clarity. The main purpose of specification is to find a connection between the general legal rule and the circumstances of the actual reality. The interpreter should transfer the abstract content of legal provision to a more specific level, because after that the provision should become more meaningful. Specification is a special form that enables the abstract provision to become concrete, and therefore, its content becomes more accurate and clearer because of interpretation.

In order to specify the evaluative concept of "gross breach of work duties," and therefore to facilitate the law application, it should be legislated that gross breach of work duties occurs in the cases when pecuniary damage caused by illegal behaviour of the worker exceeds a certain minimum legally fixed (for example, 10 minimum wages), and nonpecuniary one - if the violation of rights and interests not only led to moral suffering, loss of normal life connections and for additional efforts to organize the life of an individual employee, but also caused a deterioration of the image and credibility of an individual enterprise, institution or organization and the relevant service in general.

It is not contrary to the current labour law if the evaluative concept under study is specified directly in the local acts of the enterprise or in the employment contract by stating the specificities established, such as (a) losses incurred by the employer, payment of fines; (b) breach of law in financial utilization; (c) failure to pay taxes, fees and mandatory payments; (d) breach of the procedure for settlements; (e) permitting of growth of overdue accounts payable; (f) failure to submit financial statements. 
One-time gross breach of work duties as the ground for termination of the employment contract at the initiative of the employer

\section{Conclusions to Chapter 1}

The study of the legal nature and types of work duties of workers, as well as the essential features of the category "gross breach of work duties" enabled to make certain scientific and theoretical conclusions and formulate proposals as follows:

1. Due to the lack of clarity and consistency in the regulation of labour relations, employees often find themselves in a certain legal vacuum. In turn, the social and legal insecurity of the employee does not contribute to their being interested in the results of their work and in the stability of such relations. The challenge for the labour law of Ukraine is to create the legal framework required in modern conditions and aimed at achieving a balance of interests of the parties to the employment contract, economic growth, productivity enhancement and human well-being. These goals can be achieved only in the conditions of high internal organization of the system of labour law, smoothness and consistency of the legal framework.

2. The will of the worker and the employer as participants in the employment relationship is realized by fulfilling their reciprocal rights and obligations. The establishment of these legal relationship means the regulation of the worker's performance, on the one hand, and the employer, on the other.

Legal duties of a person, as well as rights, are necessary means of legal influence on public relations. Neither law nor duty exists without each other. A person can enjoy any right only if it is respected and adhered by others. With regards to the priority between rights and responsibilities, we prefer the former, because the internal logic of the legal matter construction is subordinated mainly to subjective rights, which are by definition an active nodal centre of its own legal content at the level of the abstract idea of law. 
Work duties of the worker as a party to the employment relationship is a system of requirements defined by legislative and local acts in the field of labour regarding specified behaviour of the employee in the course of the work under the employment contract, due to the interests of the employer and state-guaranteed coercive measures.

3. The system of work duties of employees includes:

a) general work duties for all without exception, employees, regardless of the legal status, ownership, industry affiliation, subordination and other features of employers for whom they work under an employment contract;

b) special sectoral ones for workers employed in enterprises, institutions and organizations engaged in a particular type of economic activity in the sectors of tangible or intangible production;

c) direct production and functional ones for the worker within his/her employment function by the employer in accordance with the employment contract concluded between them.

4. The essential features of the category "gross breach of work duties” as a labour law phenomenon include:

- this breach has caused or could cause substantial pecuniary and non-pecuniary damage to the rights or interests of employees, employers or the State;

- this category is an evaluative concept;

- subjects of this breach are special categories of employees defined by law;

- this breach is a disciplinary misdemeanour;

- breach can entail dismissal of the employee at the initiative of the employer.

5. Gross breach of work duties is the unlawful conduct of categories of workers defined by law, as a result of which other workers of the enterprise, institution, organization, the employer or the State have suffered or could have suffered substantial pecuniary and non-pecuniary damage; 
and which may entail the application, in the prescribed manner, of disciplinary action, including dismissal, to the guilty person.

We argue that scientific and regulatory approaches to a legislative and scientific-theoretical distinction into onetime gross breach of work duties by employees in general and individual categories of workers (the head of the organization (sub-office, representative office), his deputies, officials who are subject to the requirements of disciplinary statutes, etc.), as well as to recognition of all cases of one-time commission of unlawful behaviour by these persons, which can entail dismissal at the initiative of the employer, as gross breach of work duties by workers, are inappropriate. This due to the fact that it implies a substitution of categories, a basis for confusion and, in the end, law application suffers. More logical and balanced further use of two legal categories (both in labour law study and in labour law) should be as follows: (a) one-time substantive breach of work duties, in relation to employees in general and (b) one-time gross breach of work duties, in relation to special categories of workers.

6. The inclusion of evaluative concepts in the provisions of labour law should make the legal regulation of labour and associated relations in market conditions more flexible. However, to avoid the features of permissiveness due to this flexibility, it is necessary to outline the limits of the use of the relevant evaluative categories both in the legislation and in the practice of its application. The way to do this is specification, which in general is the provision of a particular object, phenomenon or process with maximum certainty and clarity. The main purpose of specification is to find a connection between the general legal rule and the circumstances of the actual reality. The interpreter should transfer the abstract content of legal provision to a more specific level, because after that the provision should become more meaningful. Specification is a special form 
that enables the abstract provision to become concrete, and therefore, its content becomes more accurate and clearer because of interpretation.

In order to specify the evaluative concept of "gross breach of work duties," and therefore to facilitate the law application, it should be legislated that gross breach of work duties occurs in the cases when pecuniary damage caused by illegal behaviour of the worker exceeds a certain minimum legally fixed (for example, 10 minimum wages), and nonpecuniary one - if the violation of rights and interests not only led to moral suffering, loss of normal life connections and for additional efforts to organize the life of an individual employee, but also caused a deterioration of the image and credibility of an individual enterprise, institution or organization and the relevant service in general.

It is not contrary to the current labour law if the evaluative concept under study is specified directly in the local acts of the enterprise or in the employment contract by stating the specificities established, such as (a) losses incurred by the employer, payment of fines; (b) breach of law in financial utilization; (c) failure to pay taxes, fees and mandatory payments; (d) breach of the procedure for settlements; (e) permitting of growth of overdue accounts payable; (f) failure to submit financial statements. 


\section{CHAPTER 2. COMPARATIVE STUDY \\ OF LEGAL REGULATION \\ OF TERMINATION \\ OF THE EMPLOYMENT \\ CONTRACT IN CASE \\ OF ONE-TIME GROSS BREACH \\ OF WORK DUTIES}

2.1. The Legal Background and History

of the Legal Framework for Dismissal

of the Employee in case of One-Time Gross Breach

of Work Duties in Ukraine

Modern Ukraine undergoes a complex, socially contradictory stage of its development, characterized by transformational changes in all sectors of society. This modernization is accompanied by substantial difficulties and troubles caused by the occurrence of new challenges and threats, in particular, in the field of labour law.

Recently, the interpretation of law not only as a superstructure of a certain socio-economic basis, but also as an extremely important component of the culture of the people has become more widespread. Regarding evaluation of the concept of the public legal system development, O. Ya. Gurevich argues that the doctrine of formation in the practice of historians has become not a means of sociohistorical analysis, but a limit: specific historical knowledge has been designed to confirm the truth of the philosophical and historical system. The scientific hypothesis by K. Marx 
has been transformed into an infallible dogma ${ }^{1}$. The cultural approach means that law is not unique to a particular formation. It should be evaluated as retaining its role in defining many basic notions, principles, categories and concepts during the development of the people, the State. According to L. D. Vostroknutov, this is the reason for the growing interest in historical and legal study, which are not only of historical value, but also are a key to understand the patterns, nature and trends of law, which only partially disappear with changing social economic formations, and in many cases are transformed in the course of statehood ${ }^{2}$. Each stage of the civilization constitutes the unity of economic, political, cultural and social space, the so-called "interior of a certain era". The latter, according to V. Lukianets, is not an ontological constant. From time to time this space undergoes radical changes ${ }^{3}$.

O. I. Reznik states that the historical and legal process is a special category of historical and legal knowledge, which expresses the continuous and infinite movement of law, duration and sequence of changes of qualitatively different periods, stages and phases in the occurrence, development and completion of legal events, phenomena, norms ${ }^{4}$.

Ukraine's economy transfers to a market under search for the optimal model of the relationship between the worker and the employer. However, the government, focusing on the immediate goals, solves the current tasks in the field of labour mainly by administrative means, without reference to long-

1 Gurevich, A. Ya. Th theory of formations and the reality of history. Vopr. Filosofii, no. 11, 1996: 31-43.

2 Vostroknutov, L. D. Genesis and development of legal provisions in the field of physical culture and healthy lifestyle of the Ukrainian people: From customary law to the legislation of the early twentieth century. Ph.D.'s thesis. National University of Internal Affairs. Kh., 2003. 211 p.

3 Lukyanets, V. Science in the interior of postmodernism. Filos. Dumka, no. 1, 2005: 3-22.

4 Reznik, O. I. Periodization of the historical and legal process: Conceptual aspects. Ph.D.’s thesis. Odessa National Law Academy. O., 2008. 190 p. 
term socio-economic, political and legal strategies. In this situation, one of the most difficult problems is overcoming stereotypes and illusions, in particular, those that exaggerate the role of the state, the capabilities of the planning system or excessive expectations of the market's ability to self-regulate labour and associated relations.

In this regard, the issue of the content and form of labour law provisions, their determinant functions and patterns of development are of particular interest. The process of forming new labour relationship requires new provisions. This is natural, because the content of law has been depending on the nature of changes in certain external factors. The study of legal concept development in the historical and legal aspect gives it a special thoroughness, because certain legal provisions have deep historical roots, moreover, change in the essence of law, its social nature depends, after all, on real specific historical conditions. A striking example of the historical and legal process is the development of legal regulation of termination of the employment contract in case of an employee's one-time gross breach of work duties.

According to 1893 Industry Statute ${ }^{1}$, in enterprises, which are not managed personally by their owners or owned by several persons, companies or joint-stock companies, the duties of the owner are performed by a special person, appointed by the owner to manage the enterprise. The latter is obliged to inform the factory inspection or mining supervision, as appropriate, within 7 days about the appointment of the manager of the enterprise, about his replacement by a new person. Therefore, at that time in labour law a figure of the head ("manager") was already separated from the employer-owner. The responsibility

1 Balabanov, M. (Eds.). Factory laws: Collection of laws, orders and clarifications on issues of Russian industrial legislation. K.: Pechat. delo, 1905. 140 p. 
of the head (in the form of a fine) for breach of law on employing workers, in particular: for failure to record or incorrect record of settlement books (Art. 153); for late payment of wages, incorrect payroll, replacement of cash payments by in-kind or monetary surrogates (Art. 155); for improper application of disciplinary actions (Art. 154). Therefore, the factory law regarded the manager as a fairly independent figure, as fines for breach of this law were levied on him personally, and only when the manager did not pay the fine for 2 weeks, the penalty was sent to the owner (Art. 152). The owner's right to dismiss the manager was not limited by labour (factory) law, as the agreement between him and the manager was considered civil.

The regulation of the labour activity of the manager as an employee is not reflected in the Statute. Wherever employment, working conditions, etc. are revealed, only workers are mentioned. The same situation existed in the countries of Western Europe: labour legislation, which developed intensively at that time, did not apply to senior officials ${ }^{1}$.

In the Statute under consideration, for the first time, the grounds for dismissal of an employee at the initiative of the employer were systematized and allocated in a separate provision (Art. 105). The manager of the factory or plant could terminate the employment contract with the employee in the following cases: a) his absence from work for more than 3 consecutive days or a total of more than 6 days a month without good reason; b) his absence from work for more than 2 consecutive weeks for good reasons; c) his being under investigation or trial on charges of criminal acts punishable by imprisonment; d) audacity or misconduct of the worker, if it threatens the property interests of the factory or the personal safety of any of the persons of the

1 Tal, L. S. Labour contract. Civilistic research. Part 1: General teachings. Yaroslavl: Gubern. Pravleniia. 1913. 422 p. 
One-time gross breach of work duties as the ground for termination of the employment contract at the initiative of the employer

factory management or persons supervising the work; e) detection of his contagious disease.

The grounds for dismissal such as audacity or misconduct of the worker should be recognized as the closest to the category "gross breach of work duties." In the late nineteenth century, M. D. Butovskii argued that while some people are embarrassed, feel trapped in the presence of those in power, people brought up in the spirit of reasonable discipline, behave with superiors completely effortlessly, performing all disciplinary subtleties reflexively. It is not difficult to understand that meticulous compliance with disciplinary requirements leaves no room for embarrassment or humiliation; on the contrary, any neglect of it, any reliance on the weakness or indulgence of the superior degrades the dignity of the subordinate ${ }^{1}$.

The audacity and misconduct as a ground for termination of the employment contract were considered as the actions of the worker, threatening the interests of the factory. Such actions included: (a) careless handling of fire, (b) smoking tobacco and keeping matches, pipes and cigarettes in the factory or plant premises, specified, at the request of the manufacturers, in the mandatory resolutions issued by the Chief Institution, (c) damage or stoppage of machines due to negligence of workers, (d) disobedience to foremen, (e) workers' abusive words or threats to the factory management or supervisors, (f) workers' demand to remove the foreman ${ }^{2}$.

The Labour Code of the RSFSR, prepared by a commission of the People's Commissariat of Justice with the participation of the People's Commissariat of Labour and the AllUkrainian Central Executive Committee, was considered and

\footnotetext{
1 Butovskii, N. D. Essays on the Modern Officer Life. St. Petersburg: N. K. Garshin, 1899. 215 p.

2 Vasiliev, D. A. Factory legislation of Russia at the end of the 19th beginning of the 20th centuries. Ph.D.'s thesis. Academy of Labour and Social Relations. M., 2001. 155 p.
} 
approved-in-principle at a meeting of the Central Executive Committee on November 4, 1918. After a collective revision in December 1918, it was published without reconsideration in The Collection of Laws and Orders of the Workers' and Peasants' Government of the RSFSR and put into effect ${ }^{1}$. Since 27January 1920, this legal document had been valid in Ukraine. According to Article 46 of the Code, the grounds of dismissal of the employee at the initiative of the employer included: a) full or partial liquidation of the enterprise, institution or farm, as well as the abolition of certain obligations or works; b) suspension of work for a period of more than one month; c) expiration of the term of performance of work, if it was temporary; d) obvious unfitness of the employee to work.

According to Article 47 of the LC of Ukrainian SSR of $1922^{2}$, the grounds for termination of the employment contract at the initiative of the employer are:

- complete or partial liquidation of the enterprise, institution or farm, as well as reduction of work in them;

- suspension of work for a period of more than one month for production reasons;

- detection of unfitness of the worker to perform the work;

- systematic non-fulfilment by the employee without good reasons of the obligations under the contract or the rules of internal labour regulations;

- the employee's commission of a crime directly related to his/her work in accordance with an enforceable court judgement, as well as his/her detention for more than 2 months;

- absence from work for more than 3 sequential days or a total of more than 6 days a month without good reason;

1 Labour Code of the RSFSR (approved by Resolution of ACEC of 10 December 1918). The Collection of Laws and Orders of the Workers and Peasants' Government of the RSFSR No. 87-88, 1918. Art. 905.

2 Labour Code Laws of the USSR (approved by Resolution of AUCEC of 02 December 1922). The Collection of Laws of the USSR No. 52, 1922. Art. 751. 
- the employee's absence from work due to temporary disability after 2 months from the date of its beginning, and in case of temporary disability after pregnancy and childbirth, after 2 months over the established 4-month period.

In addition to the cases provided for by the general labour legislation, dismissal at the initiative of the employer was also carried out on the basis of special regulations.

Regulation on disciplinary liability by subordination, approved by the Resolution of the All-Ukrainian Central Executive Committee and the Council of People's Commissars of the USSR of 17 October $1928^{1}$, provided for that disciplinary measures, including dismissal, were applied to all officials if, due to minor misconduct of certain categories of employees, bodies and persons empowered to apply disciplinary measures, bodies of court, investigation, prosecutorial supervision or workers and peasants' inspection do not recognize the case as criminal.

Disciplinary actions were applied:

- in relation to members of local Soviets and executive committees, by the relevant Soviets and executive committees, as well as by all higher executive committees and their presidiums, the Council of People's Commissars of the USSR and the Presidium of the All-Ukrainian Central Executive Committee;

- in relation to members of the presidium of local executive committees, by higher executive committees and their presidiums, the Council of People's Commissars of the USSR and the Presidium of the All-Ukrainian Central Executive Committee;

- in relation to other officials, by the heads of relevant institutions or organisations, as well as persons and bodies in the chain of command.

\footnotetext{
1 Regulation on disciplinary liability by subordination (approved by Resolution of ACEC and the CPC of the USSR of 17 October 1928). SU USSR No. 29, 1928. Art. 252.
} 
Moreover, the framework of disciplinary legislation of the USSR and the Union Republics, approved by the Resolution of the CEC and the Council of People's Commissars of the USSR of 13 October $1929^{1}$, in relation to managers and other decision makers provided for dismissal for a one-time culpable failure to perform their work duties, taking into account the nature of functions performed by these persons.

The list of decision makers was initially established by the People's Labour Commissariats of the USSR and the Union Republics in agreement with the All-Union Central Council of Trade Unions and the Republican Soviet of Trade Unions, and later by the Presidium of the Supreme Council of the USSR. Thus, according to the Decree of the Presidium of the Supreme Council of the USSR in 1957, the responsible decision makers are:

- heads of enterprises, institutions, organizations, construction departments, farms, their deputies and assistants; managers (directors) of shops, public catering establishments, consumer service enterprises, bases and warehouses, their deputies (except for managers of shops, public catering establishments and warehouses who do not have employees under their authority);

- chief engineers, chief physicians, chief accountants (senior accountants where there are no chief accountants), their deputies; chief designers, chief mechanics, chief electricians and other chief specialists;

- heads of workshops (laboratories and workrooms as workshops); senior masters and masters; construction site supervisors and senior contractors; heads (managers) of departments at enterprises; heads of production sites and services; foresters in forestry;

1 Decree of the Presidium of the Supreme Council of the USSR on approval of the Regulation on the procedure for the consideration of labour disputes of 31 January 1957. Vedom. Verkhov. Soveta SSSR, no. 4, 1957. Art. 58. 
- heads of departments, divisions and other similar subdivisions in ministries, government agencies, institutions of Union, republican, regional and oblast status, their deputies; managers of departments of executive committees of district and city Soviets of workers' deputies;

- editors-in-chief and their deputies; executive secretaries of editorial offices;

- teaching staff of higher educational institutions and employees of research institutions, whose positions are replaced by competition;

- prosecutors, assistants of prosecutors, senior investigators, investigators;

- elected employees holding paid positions;

- instructors, inspectors, managers of trade union departments;

- artists and other creative workers of theatres, ensembles, orchestras, choirs, philharmonics and other concert organizations, whose positions are replaced by competition.

All officials who held positions as a result of the elections were also liable by subordination. All other employees were subject to liability in the manner prescribed by the rules of internal regulations and the penalty tables attached to them.

Disciplinary punishment in the chain of command could not be imposed later than one month from the date of detection of the misdemeanour, and in specially established cases, from the date of termination of the criminal case. At the same time, such a penalty was not imposed in any case later than 6 months from the date of the misdemeanour. This period did not include the time of the criminal proceedings. An explanation was required from the person prosecuted prior to disciplinary action. A reasoned decision to impose a penalty was immediately notified to this person, and after the entry into force it was announced at the institution or 
enterprise whereby the employee was in an employment relationship. Dismissals for elected officials were made in the form of their recall by decision $s$ of the bodies that elected them.

The imposition of a disciplinary action in the chain of command did not become an obstacle to the prosecution regarding the same breach. But if such a penalty has not yet been enforced, the latter has been suspended pending a criminal case.

The decision to impose a disciplinary action in the chain of command within two weeks could be appealed by the person on whom the sanction was imposed. Complaints were submitted directly to a higher official or body against the official or body that imposed the penalty. Decisions on complaints were considered final and reviewed only under the supervision of higher authorities.

According to special laws of the USSR and the Union Republics, certain categories of workers (workers and peasants' militia, administrative and military staff of places of imprisonment, security of roads of the People's Commissariat of Railways, security of enterprises and buildings of special state importance, etc.) and certain types of disciplinary misconduct (for example, breach of technical rules that caused events related to railway traffic by railway workers, etc.) could be a deviation from the above rules of liability in the chain of command.

The Resolution of the CEC and the Council of People's Commissars of the USSR of July 7, $1932^{1}$ “On the liability of employees of institutions and the administrative apparatus of economic bodies for breach of the rules for the general and fire protection of office buildings and premises and the rules for storing office documents” established that in case

\footnotetext{
1 Resolution of the CEC and the CPC of the USSR of 13 October 1929 on the Basics of Disciplinary Legislation of the USSR and Union Republics. SZ USSR, no. 75, 1929. Art. 723.
} 
of one-time gross breach of work duties guilty employees of these institutions and the corresponding administrative apparatus of economic bodies could be discharged.

Disciplinary actions are imposed no later than 10 days from the date of detection of the misdemeanour. Prior to this, the employee is required to provide written or oral explanations. In case of non-receipt of them within 3 days, the administration has the right to impose a penalty. Taking a disciplinary action should consider: (a) the circumstances under which the breach was committed; (b) damage caused by the breach; (c) the employee's previous performance.

The imposed penalty could be appealed within 5 days from the date of its announcement directly to a higher official in relation to the official who imposed the penalty. The decision on the complaint was final and could not be reconsidered.

Dismissal for one-time gross breach of work duties also applied to certain categories of employees who were subject to disciplinary statutes. For example, a disciplinary action in the form of dismissal could be applied to those railway workers whose activities are related to the movement of trains and passenger service, if such employees have endangered the safety of traffic regulations in passenger service (para. 20 of the Statute on discipline for railway transportation employees of the USSR, approved by the Resolution of the Council of Ministers of the USSR of 31 July $1964^{1}$ ).

Para. 26 of the Internal Labour Regulations for workers and employees of the coal industry of 8 February 1957 allowed the administration to dismiss engineers, workers and employees of the coal and shale mines operating or under construction in case of gross breach of safety rules ${ }^{2}$.

\footnotetext{
1 Resolution of Council of Ministers of the USSR on the approval of the Statute on discipline for railway transportation employees of the USSR No. 636 of 31 July 1964. SP USSR, no. 13, 1964. Art. 91.

2 Mishutin, A. N. (Ed.). Commentary on labour legislation. 2nd ed. M.: Yurid. lit., 1967. 856 p.
} 
According to Art. 106 of the Fundamentals of Labour Legislation of the USSR and the Union Republics ${ }^{1}$, adopted on 15 July 1970, one-time gross breach of work duties by an employee, subject to disciplinary responsibility in the chain of command was recognized as a special ground for termination of the employment contract on the initiative of the administration of the enterprise, institution, organization. The same wording was later transferred to para. 1 of Part 1 of Art. 41 of the LC of the USSR. During the period of temporary incapacity for work, as well as the employee's leave, his/her dismissal on this ground was not allowed.

The categories of employees, subject to disciplinary liability in the chain of command were determined by List No. 1 of Appendix No. 1 to the Regulations on the Procedure for Considering Labour Disputes, approved by the Decree of the Presidium of the Supreme Council of the USSR of 20 May 1974 . Such employees included:

- heads of enterprises, institutions, organizations, their deputies and assistants; managers (directors) of shops, public catering establishments, consumer service enterprises, bases, their deputies (except for managers (directors) of shops, public catering establishments, consumer service enterprises, who do not have employees under their authority);

- chief engineers, chief physicians, chief accountants (senior accountants, in the absence of chief accountant position), their deputies; chief designers, chief mechanics, chief electricians and other senior specialists of the enterprise; legal advisers appointed by the next higher authority;

- heads of workshops and their deputies, heads (administrators, managers) of departments, services, sections, productions, farms and heads of other structural

1 Fundamentals of the Legislation of the USSR and the Union Republics on Labour (approved by Law of the USSR No. 2-VIII of 15 July 1970). Vedom. Verkhov. Soveta SSSR, no. 29, 1970. Art. 265. 
subdivisions of enterprises, who have subordinates, as well as organizations that enjoy the rights of a public production enterprise; directors of creative and productioncreative associations, film studios, film directors; masters; chiefs of construction sites and senior executors of works of construction organizations; warehouse managers who have employees under their authority; foresters;

- heads of departments, divisions (divisions in departments) and other similar subdivisions in ministries, government agencies, institutions and organisations of Union, republican, regional and oblast status, their deputies; managers of departments of executive committees of district and city Soviets of workers' deputies;

- editors-in-chief and their deputies; executive secretaries of editorial offices; managers of editorial offices, departments and chief artists of publishing houses; managers of editorial offices, chief and responsible issuers, chief artists, reviewers of TASS main editions; managers of departments, commentators and reviewers of the main editorial offices of radio and television;

- prosecutors, their deputies and assistants, investigators;

- elected employees holding paid positions;

- district inspectors and engineers-inspectors of the State Mining Inspectorate of the USSR; senior public inspectors at the Autonomous Republic, regions, oblasts and district public inspectors of fishery protection bodies, senior public inspectors from conventional fisheries;

- directors of directorates, department administrators, managers of agencies, referents, inspectors, foreign correspondents, guides-translators, translators, managers of service bureaus, translators of service bureaus, inspectorsacquirers of organizations of the Main Department for Foreign Tourism under the USSR Council of Ministers;

- employees with diplomatic ranks, diplomatic couriers, referents of the Ministry of Foreign Affairs of the USSR; 
- employees of central, republican, regional, oblast, city (in cities of oblast and republican subordination) public organizations, approved for the position by a collegial body;

- employees of the Main Customs Department of the Ministry of Foreign Trade of the USSR and other customs institutions of the USSR who have personal ranks.

In Soviet times, Chapter XV "Labour Disputes" of the LC mentions the category of "explicit breach of law." According to Art. 238 of this Code, the court imposes on an official guilty of unlawful dismissal or transfer of an employee to another job, the obligation to compensate the damage caused to the enterprise, institution, organization in connection with payment for the period of forced absence or the period of this employee's performance of lower paid work. Therefore, this obligation is imposed if the dismissal or transfer was a clear breach of law. According to para. 25 of the Resolution of the Plenum of the Supreme Court of the USSR "On the application by courts of legislation regulating the conclusion, amendment and termination of an employment contract" no. 3 of 26 April $1984^{1}$, the notion "explicit breach of law" is dismissal of:

- the chairman of the group of people's control of the enterprise or his transfer by way of disciplinary action to lower-paid work without the consent of the district, city, district committee of people's control in the city;

- an employee without the consent of the trade union committee or on grounds not provided by law;

- a people's deputy or his/her transfer for a disciplinary reason to a lower-paid job without the consent of the relevant Council, and between sessions, of the Executive Committee of the Council of People's Deputies or the Presidium of the Verkhovna Rada;

\footnotetext{
1 Resolution of the Plenum of the Supreme Court of the USSR on the application by courts of legislation regulating the conclusion, amendment and termination of an employment contract No. 3 of 26 April 1984. Biul. Verkhov. Suda SSSR, 1984. Art. 329.
} 
- the head of the people's control group of the enterprise or its transfer for a disciplinary reason to lower-paid work without the consent of the district, city, district in the city committee of people's control;

- women in cases provided by law, when the administration was aware of the existence of circumstances that preclude the possibility of their dismissal;

- workers and officials under the age of 18 without the consent of the district (city) commission on underage persons;

- as well as transfer to another permanent job without the consent of the employee, etc.

Moreover, the involvement of an official, by whose order the employee was illegally dismissed or transferred, in the case by the third party as the defendant had to be decided, as a rule, by a judge in preparing the case for trial, which does not rule out consideration of the issue in court. Such involvement of the official does not deprive him of the right to act on the case as a representative of the defendant.

In the Law of Ukraine "On Amendments to the Code of Labour Laws of the Ukrainian SSR during the transition to a market economy" adopted by the Verkhovna Rada of Ukraine on 20 March 1991, the legislator abandoned the above evaluative category, and Art. 238 of the LC was worded as follows: "The court imposes on an official guilty of unlawful dismissal or transfer of an employee to another job, the liability to reimburse damages caused to an enterprise, institution, organization in connection with payment for forced absence or for the performance of lower paid work. This liability is imposed if the dismissal or transfer is carried out with a clear breach of law or if the owner or his authorized body has delayed the execution of the court's decision to reinstate the employee" ${ }^{1}$.

1 Law of the USSR on amendments to the Code of Labour Laws of the Ukrainian SSR during the transition to a market economy No. 871-XII of 20 March 1991. Vidomosti Verkhovnoi Rady USSR. Art. 267. 
In many sectors of the national economy, according to statutes of discipline, adopted in the 70-80s of the twentieth century, a special ground for termination of the employment contract was the commission of a gross breach of work duties.

For example, the Statute on Discipline for workers employed in hazardous underground conditions, approved by the Resolution of the Council of Ministers of the USSR No. 974 of 30 November $1976^{1}$, required the employee:

- to know his/her job well, to perform his/her duties accurately and in a timely manner, to show the necessary initiative, to constantly improve business skills;

- to know and strictly adhere to the rules and provisions for safe work, rules of technical operation, industrial sanitation, fire protection, instructions on labour protection, as well as job descriptions;

- to duly pass examinations on rules, provisions and instructions on safe conducting of works;

- follow the instructions of supervisory authorities;

- to strictly adhere to the procedure for timekeeping of descent to underground works and departure (exit) from these works;

- to systematically examine workplaces and equipment and take measures to immediately eliminate the identified breach of rules, regulations and instructions for safe work;

- to be at work in special clothes and to use means of individual protection;

- to stop work in the event of dangerous conditions, to immediately notify the supervisor, and in case of accident to act in strict accordance with the plan to eliminate the accident;

- to take due care of property;

\footnotetext{
1 Resolution of the Council of Ministers of the USSR on approval of the Statute on discipline for workers employed in hazardous underground conditions No. 974 of 30 November 1976. SP SSSR, no. 1, 1977. Art. 1.
} 
One-time gross breach of work duties as the ground for termination of the employment contract at the initiative of the employer

- to increase productivity, to fulfil the established production norms (time norms), to achieve high quality indicators in work, etc.

The manager, in turn, is responsible for the state of discipline among subordinates and is obliged to properly organize the work of subordinates, set an example of conscientious performance of official duties, clearly give orders and instructions to subordinates and check their implementation.

If a disciplinary action in the form of dismissal can be applied to workers and employees for systematic nonfulfilment without good reason of the obligations imposed by the employment contract or the Statute on discipline of workers employed in particularly dangerous underground conditions, for truancy without good reason (including appearance at work in a state of intoxication), as well as for breach of safety rules and instructions for safe work, the dismissal is applied to managers even for one-time gross breach of work duties. In the sector under consideration, managers are:

- a director (head), his deputy and production assistant;

- a chief engineer, his deputy and assistant;

- a chief technologist, his deputy;

- heads of departments, such as production, technical, labour protection and safety, their deputies;

- the head and a chief engineer of the capital construction department, their deputies for mining works;

- a chief (senior) mechanic, power engineer, surveyor, geologist, hydrogeologist, their deputies, senior electrician;

- chiefs of shift, ventilation service, drilling and blasting service, their deputies and assistants;

- a chief (senior) dispatcher, dispatcher for mining operations;

- a surveyor, geologist, hydrogeologist;

- head of the mining workshop, his deputy and assistant; 
One-time gross breach of work duties as the ground for termination of the employment contract at the initiative of the employer

- chief, mechanic and master of lifting;

- a site manager, his deputy and assistant, senior contractor, contractor, shift engineer, foreman, mechanic, power engineer, electrician, if they have employees engaged in work in particularly dangerous underground conditions.

According to the Statute on Discipline of Railway Transport Workers of the USSR, approved by the Resolution of the Council of Ministers of the USSR No. 748 of 7 August $1985^{1}$, guilty breach by an employee of discipline in the performance of work duties, as well as established rules of conduct in working premises and on the territory of railway transport enterprises, including passenger trains, even if it is not committed in duty status, is a disciplinary misdemeanour this breach does not entail criminal liability. For workers, directly involved in rail transport, the operation of escalators, the passenger service and the safeguarding of goods and facilities, a disciplinary action in the form of dismissal may be applied for one-time gross breach of (a) discipline that threatens traffic safety, human life and health; and (b) rules established for the carriage and passenger service and the safety of goods and facilities. Lists of gross breaches of the discipline that threaten traffic safety, life and health, and categories of workers dismissed without the consent of the trade union committee, should be approved by the Ministry of Railways upon the approval of the Central Committee of the union.

According to the Statute on Discipline of employees of the Ministry of Atomic Energy of the USSR, approved by the Resolution of the Council of Ministers of the USSR No. 390 of 2 April $1987^{2}$, failure or improper performance of his/her

1 Resolution of the Council of Ministers of the USSR on approval of Statute on discipline of railway transport workers of the USSR No. 748 of 7 August 1985. SP SSSR, no. 24, 1985. Art. 123.

2 Resolution of the Council of Ministers of the USSR on approval of Statute on discipline of employees of the Ministry of Atomic Energy of the USSR No. 390 of 2 April 1987. SP SSSR, no. 25, 1987. Art. 87. 
work duties for reasons attributable to the employee, as well as the established rules of conduct in working premises and territory, even if the breach is not committed in duty status, is a disciplinary misdemeanour, if this breach does not entail criminal liability. Dismissal as a disciplinary action may be applied to an employee for one-time gross breach of discipline that threatens the safety of nuclear power plants and other nuclear power facilities or endangers human life and health. Lists of gross breach of discipline and categories of workers dismissed without the consent of the trade union committee are approved by the Ministry of Atomic Energy of the USSR in agreement with the Central Committee of the Trade Union of Power Plants and the Electrical Industry. Employees who have committed misdemeanour, which endangers the safety of trains, life and health of people, may, if required, be suspended from work by an official who performs administrative or control functions in the area, with immediate notification to the manager in charge. The notification must detail the reasons and circumstances that led to the dismissal of the employee.

According to para. 25 of the Statute on Discipline of workers and employees of ships supporting the navy, approved by the Resolution of the Council of Ministers of the USSR No. 32 of 9 January $1986^{1}$, a disciplinary action in the form of dismissal may be applied for:

- systematic non-fulfilment by the worker or employee without good reasons of his/her work duties, if disciplinary or public sanctions have previously been imposed on him/ her, as well as truancy (including the absence from work for more than 3 hours during a working day) without good reasons or appearing on working place in a state of intoxication;

\footnotetext{
1 Resolution of the Council of Ministers of the USSR on approval of Statute on discipline of workers and employees of ships supporting the navy No. 32 of 9 January 1986. SP SSSR, no. 5, 1986. Art. 31.
} 
- gross breach of discipline that threatens safe navigation, or endanger human life and health;

- committing during the stay abroad misdemeanour, incompatible with the honour and dignity of a citizen of the USSR, or breach of customs rules.

The dismissal of workers is conducted upon the approval of the trade union committee, except cases provided by the legislation of the USSR, as well as gross breach of discipline, that threatens safe navigation and human life and health. The list of gross breach of discipline, and categories of workers and employees dismissed without the consent of the trade union committee, should be approved by the Ministry of defence of the USSR upon the approval of the relevant Central Committee of the union.

In order to increase the efficiency of state customs control, strengthen the counteraction to smuggling and breaches of customs rules, required in all parts of state customs control high organization, vigilance, strict discipline and effectiveness, exemplary attitude of employees to performance of their duties, therefore, the Resolution of the Council of Ministers of the USSR of October 9, 1987 approved the Statute on Discipline of employees of the State Customs Control of the USSR ${ }^{1}$. A disciplinary action in the form of dismissal could be applied to the worker for gross breach of the procedure for the State Customs Control. The list of gross breach was approved by the General Directorate for State Customs Control under the Council of Ministers of the USSR upon the approval of the Central Committee of the union of public institution officials.

In order to improve the regulation of labour relations under the country's transition to a market economy, on 20 March 1991, the Supreme Council of the USSR amended

\footnotetext{
1 Resolution of the Council of Ministers of the USSR on approval of Statute on discipline of employees of the State Customs Control of the USSR No. 1130 of 9 October 1987. http://www.lawmix.ru/docs_cccp/2511.
} 
One-time gross breach of work duties as the ground for termination of the employment contract at the initiative of the employer

para. 1 of Art. 41 of the LC, according to which the owner or his authorized body has the right to terminate the employment contract only with managers of the enterprise in the case of their one-time gross breach of work duties. Since 18 February $1992^{1}$, according to Art. 233 of the LC of Ukraine, the district (city) people's courts directly considered labour disputes on the applications of the head of the enterprise, institution, organization (suboffice, representative office, branch, other separate division), his deputies, executives, elected, approved or appointed by public authorities and administration, as well as public organizations and other associations of citizens, on dismissal, change of date and formulation of the reason for dismissal, transfer to another job, payment for the period of the forced truancy and imposition of disciplinary actions.

According to Art. 43-1 of the LC of Ukraine, termination of the employment contract at the initiative of the owner or his authorized body without the consent of the trade union body is allowed in case of dismissal of the dismissal of the head of the enterprise, institution, organization (suboffice, representative office, branch, other separate division), his deputies, executives elected, approved or appointed to positions by public authorities and administration, as well as public organizations and other associations of citizens.

On 6 November 1992, the Plenum of the Supreme Court of Ukraine adopted Resolution No. 9 "On the consideration of labour disputes", which provided for in para. 27 that the court, deciding whether breach of work duties is gross, should proceed on the of nature of misdemeanour, the circumstances under which it was committed, and the damage caused by it (could be caused).

\footnotetext{
1 Law of Ukraine on amendments and addenda concerning the consideration of individual labour disputes to the Labour Code of the Ukrainian SSR and recognition of certain legal regulations as repealed No. 2134-XII of 18 February 1992. Vidomosti Verkhovnoi Rady Ukrainy, no. 22, 1992. Art. 302.
} 
The Law of Ukraine "On Amendments to the Labour Code of Ukraine concerning the procedure for dismissal of certain categories of employees" of 19 November $1993{ }^{1}$ provided for the enlarged range of persons dismissed by the employer for one-time gross breach of work duties that include: the head of the enterprise, institution, organisation (suboffice, representative office, branch, other separate division), his deputies, chief accountant, his deputies, as well as officials of the revenue and duties bodies nominated for special ranks, and officials of central executive bodies implementing national policy in public financial control and price control.

On 17 October 2002, the Law of Ukraine "On Amendments to Articles 41 and 134 of the Labour Code of Ukraine" ${ }^{2}$ singled out of one-time gross breach of work duties as an independent ground for termination of the employment contract a commission of guilty acts by this subject, as a result of which wages were paid late or in the amount lower than the statutory minimum wage.

$\mathrm{Yu}$. V. Isaiev ${ }^{3}$ argues that this was due to numerous breaches of wage payment frequency and the presence of arrears in recent months at enterprises of all forms of ownership. The analysis of the situation with debt repayment reveals that in addition to economic reasons, an important condition for the existence of this phenomenon is a subjective factor of the faulty acts of managers. V. I. Shcherbyna advocates this legal innovation because Part 4 of Art. 41 of the Constitution of Ukraine guarantees

1 Law of Ukraine on amendments to the Labour Code of Ukraine concerning the procedure for dismissal of certain categories of employees No. 3632-XII of 19 November 1993. Vidomosti Verkhovnoi Rady Ukrainy, no. 49,1993 . Art. 461.

2 Law of Ukraine on amendments to Articles 41 and 134 of the Labour Code of Ukraine No. 184-IV of 17 October 2002. Vidomosti Verkhovnoi Rady Ukrainy, no. 47, 2002. Art. 355.

3 Isaiev, Yu. V. Special grounds for termination of the employment contract at the initiative of the employer. Ph.D.'s thesis. T. Shevchenko Kyiv National University. K., 2012. 213 p. 
One-time gross breach of work duties as the ground for termination of the employment contract at the initiative of the employer

that no one may be unlawfully deprived of property rights. Property rights are unbreakable. All legal subjects, including employers, must strictly adhere to these requirements. Therefore, the inclusion of para. 1-1 of Part 1 of Art. 41 of the LC is a logical continuation of protecting the employee's right to receive wages for work performed within the time limits specified in the collective agreement ${ }^{1}$.

Decree of the President of Ukraine No. 726/2012 of 24 December 2012 "On some measures to optimize the system of central executive bodies" initiated administrative reform ${ }^{2}$. According to this Decree, the Ministry of Revenue and Duties of Ukraine was established, and the State Customs Service of Ukraine and the State Tax Service of Ukraine were reorganized. In this regard, on 4 July 2013, in accordance with the Law of Ukraine "On Amendments to several legislative acts of Ukraine in connection with holding the administrative reform" ${ }^{3}$, in paragraph 1 of part 1 of Art. 41 of the LC of Ukraine, the words "officials of customs bodies, state tax inspections, nominated for personal ranks” were replaced with the words "officials of the bodies of revenue and duties, nominated for special ranks in public financial control and price control.”

During the years of Ukraine's independence, the statutes and regulations on discipline preserved the practice of Soviet times, that is, the use of the wording "one-time gross breach of work duties”. For example, according to Art. 28 of the Disciplinary Statute of the Customs Service of Ukraine ${ }^{4}$,

1 Shcherbyna, V. I. Labour Law of Ukraine. K.: Istyna, 2008. 384 p.

2 Decree of the President of Ukraine on some measures to optimize the system of central executive bodies No. 726/2012 of 24 December 2012. Ofith. Visn. Prezydenta Ukrainy, no. 35, 2012. Art. 842.

3 Law of Ukraine on amendments to several legislative acts of Ukraine in connection with holding the administrative reform No. 406-VII of 04 July 2013. Vidomosti Verkhovnoi Rady Ukrainy, no. 20-21, 2014. Art. 712.

4 Law of Ukraine on Disciplinary Statute of the Customs Service of Ukraine No. 2805-IV of 06 September 2005. Vidomosti Verkhovnoi Rady Ukrainy, no. 42, 2005. Art. 467. 
dismissal of a customs official can be in case of one-time gross breach, namely:

- for extortion or receipt of gifts, things, currency of Ukraine, foreign currency in connection with the performance of official duties, both during their performance and off-duty hours;

- for substitution, theft or intentional damage of items subject to customs control;

- for detention, seizure and acceptance for storage of objects, currency values without registration in the order prescribed by law;

- for disclosure of state secrets and confidential information owned by the state, legal or natural person, other secrets protected by law, loss or intentional tampering with material carriers of secret and confidential information, as well as transfer of weapons and special means of protection, customs support to third parties;

- for brutal or contemptuous treatment of citizens during the performance of official duties, humiliation of their honour and dignity.

Article 58 of the Disciplinary Statute of the Civil Defence Service ${ }^{1}$ provides for that gross disciplinary misdemeanour is the fact of gross breach of discipline that does not involve features of criminal offense, such as:

- absenteeism without good reason;

- breach of the agenda established by the head of the body or unit of civil protection;

- use of alcoholic beverages or drugs during office hours, appearing on working place in a state of alcoholic, narcotic intoxication;

- breach of Statute's rules of service;

- loss of service certificate, official documents;

1 Law of Ukraine on Disciplinary Statute of the Civil Defence Service No. 1068-VI of 05 March 2009. Vidomosti Verkhovnoi Rady Ukrainy, no. 29, 2009. Art. 398. 
- non-fulfilment of orders and directives of superiors, which led to unpreparedness for actions on purpose and to disruption of tasks assigned to the body or department of civil defence;

- breach of legal provisions and other legal regulations, that resulted in damage or loss of the fixed property, equipment and technique, other material losses, as well as the damage to the health of the personnel of the body or unit in civil defence or to other persons;

- non-fulfilment of individual work plans by academic, academic teaching, teaching staff, postgraduate students, persons working for doctor's degree.

However, this Statute does not contain a provision requiring that a gross disciplinary misdemeanour is grounds for dismissal of members of the rank-and-file and command staff of civil defence bodies and units. This legal phenomenon is only mentioned in the legal regulation as follows:

a) in case of gross breach of service discipline, direct superiors in cases that do not allow delay, may suspend the rank-and-file and command staff from duties (Art. 61 of the Statute);

b) the decision of the superior to impose a disciplinary action on a subordinate for substantial gross disciplinary misdemeanour may be preceded by an official investigation ordered by the superior to clarify all the circumstances, as well as clarify the reasons and conditions that led to the disciplinary offense, the gravity of the offense and the amount of damage caused (Article 83 of the Statute).

A different approach is enshrined in the Regulations on Discipline of railway transport workers, approved by the Resolution of the Cabinet of Ministers of Ukraine No. 55 of 26 January $1993^{1}$. According to its paragraph 15,

\footnotetext{
1 Resolution of the CMU on approval of Regulations on Discipline of railway transport workers No. 55 of 26 January 1993. ZP Ukrainy, No. 4-5, 1993. Art. 71.
} 
disciplinary action in the form of dismissal applies to employees for breach of discipline, the effects of which threaten the safety of trains, life and health of citizens, as well as to the categories of employees specified in the annex to this legal regulation. This Regulation contains a list of types of disciplinary breaches, the effects of which threaten the safety of trains, life and health of citizens, as well as categories of employees to whom disciplinary action is applied in the form of dismissal, namely:

- appearance (presence) at work in a state of alcohol, drugs or other intoxication. This breach concerns: locomotive drivers and their assistants, drivers of fixed motor-rail vehicles, station duty officers, train dispatchers, senior duty officers (duty officers) of pointsman's box, senior electromechanics (electromechanics) of signaling, signaling arrangement, tracks track foreman, section foreman, level-crossing attendant, car inspectors, car repairmen inspectors, car repairman, train chiefs, conductors of passenger cars, train electricians, senior receivers (receivers) of cargo and luggage, train assemblers, train assemblers; car pointsman;

- signal passed at danger (irrespective of consequences) for reasons attributable to the locomotive driver, drivers of fixed motor-rail vehicles; this concerns: drivers of locomotives, drivers of fixed motor-rail vehicles;

- departure of a train for an occupied track section or its acceptance on an occupied track, departure of a train on an unprepared route, throwing of points under a train; this concerns: station duty officers, train dispatchers, senior duty officers (duty officers) of pointsman's box, senior electromechanics (electromechanics) of signaling;

- non-protection with stopping signals of track work sites; this concerns: supervisors, track foremen, section foremen;

- collision at a crossing equipped with an automatic level crossing safety installation and a level-crossing gate, due 
One-time gross breach of work duties as the ground for termination of the employment contract at the initiative of the employer

to equipment failure or breach of work duties by a levelcrossing attendant; this concerns: senior electromechanics (electromechanics) of signalling, track foreman, levelcrossing attendant;

- allowance of cases of erroneous indication of the clear signal instead of the restrictive one at the wayside signal due to unsatisfactory maintenance of the signalling equipment; this concerns: senior electromechanics (electromechanics) of signalling;

- non-compliance with specifications and rules of cargo fastening, which led to breach of operation safety requirements; this concerns: senior receivers (receivers) of cargo and luggage;

- fire in passenger cars due to negligence in their work duties; this concerns: train supervisors, train electromechanics, passenger car attendant.

Therefore, only appearance at work in a state of alcohol, drugs or other intoxication is provided for by para. 7 of Art. 40 of the LC as the general basis for termination of the employment contract at the initiative of the employer. Other grounds for dismissal are specific and apply only to the categories of railway workers prescribed by law.

The results of a comprehensive study in the second sub-section of the monograph enable to make conclusions of significant theoretical and applied significance.

1. Ukraine undergoes transition to a market economy in terms of finding the optimal model of employeeemployer relationship. However, the State authority, focusing on the immediate goals and current objectives in the field of labour, solves them mainly administratively, without imposing long-term socio-economic, political and legal strategies. In this state of affairs, one of the most difficult problems is overcoming stereotypes and illusions, in particular, exaggeration of the State function, the planning and command system capabilities or excessive 
expectations of the market's ability to self-regulate labour and associated relations.

In this regard, the issue of the content and form of labour law provisions, their determinant functions and patterns of development are of particular interest. The process of forming new labour relationship requires new provisions. This is natural, because the content of law has been depending on the nature of changes in certain external factors. The study of any legal concept development in the historical and legal aspect gives it a special thoroughness, because certain legal provisions have deep historical roots, moreover, change in the essence of law, its social nature depends, after all, on real specific historical conditions.

2. The factory law regarded the manager (administrator) as a fairly independent figure. For example, fines for breach of this law were levied on him personally, and only when the manager did not pay the fine for 2 weeks, the penalty was sent to the owner. The latter's right to dismiss the manager was not limited by law, as the agreement between him and the manager was considered civil. The regulation of the labour activity of the manager as an employee is not reflected in law. Wherever employment, working conditions, dismissal, etc. are revealed, only workers are mentioned.

3. The formation and development of legal regulation of the termination of the employment contract in case of worker's one-time gross breach of work duties includes the periods as follows:

1st (1928-1969) the stated ground for dismissal is launched for managers and other decision makers, taking into account the nature of their work function. The lists of decision makers were initially established by the People's Labour Commissariats of the USSR and the Union Republics upon the approval of the All-Union Central Council of Trade Unions and the Republican Soviet of Trade Unions, and later by the Presidium of the Verkhovna Rada or the Council of Ministers. 
At different times, these employees include not only the heads of enterprises, their deputies and assistants, chief engineers, chief physicians, chief accountants, heads of workshops, masters, construction site supervisors, also but prosecutors and investigators; teaching staff of higher educational institutions and employees of research institutions, elected employees, instructors, inspectors, managers of trade union departments; artists and other creative workers. In the 60s of the twentieth century, dismissals for one-time gross breach were applied to certain categories of employees, subject to the regulations and statutes on discipline (railway workers, workers and employees of the coal industry).

The dismissal did not become an obstacle to the prosecution of a guilty person regarding the same breach. It could be appealed in the chain of command directly to the next higher authority or a higher official. All decisions on complaints were considered final and reviewed only under the supervision of higher authorities.

2nd (1970-1990) - for the first time, the Principles of Labour Legislation of the USSR and the Union Republics and in the LC of the USSR provide for one-time gross breach of work duties by employee, subject to disciplinary liability in the chain of command, as a separate special ground for their dismissal. The categories of employees, subject to disciplinary liability in the chain of command were determined by the special List, approved by the Presidium of the Supreme Council of the USSR. Compared to the previous period, this List additionally included employees with diplomatic ranks, as well as diplomatic couriers, referents of the Ministry of Foreign Affairs of the USSR, employees of public organizations, approved for the position by a collegial body; employees of the Main Customs Department of the Ministry of Foreign Trade of the USSR and other customs institutions of the USSR who have personal ranks, employees of the Main Department for Foreign Tourism, inspectors 
and engineers-inspectors of the bodies of the State Mining and Technical Supervision, etc. However, teaching staff of higher educational institutions and employees of research institutions, as well as artists and other creative workers are excluded from the scope.

The current LC, together with the category under study, provides for the term "explicit breach of law." An official guilty of unlawful dismissal of an employee with explicit breach of law is required to compensate the damage caused to the enterprise, institution, in connection with payment for the period of forced truancy. The explicit breach of law was dismissal of: (a) an employee without the consent of the trade union committee or on grounds not provided by law; (b) a people's deputy without the consent of the relevant Council, and between sessions, of the Executive Committee of the Council of People's Deputies or the Presidium of the Verkhovna Rada; (c) the head of the people's control group of the enterprise without the consent of the district, city, district in the city committee of people's control; (d) women in cases provided by law, when the administration was aware of the existence of circumstances that preclude the possibility of their dismissal; (e) workers and officials under the age of 18 without the consent of the district (city) commission on underage persons.

In the 70's and 80's of the twentieth century, much more sectors of the national economy adopted Statutes on discipline. The latter provided for that the special ground for termination of the employment contract was committing gross breach of work duties. This ground concerns employees of the State Customs Control, workers employed in particularly dangerous underground conditions, employees of the Ministry of Atomic Energy, workers and employees of ships supporting the navy, etc. During the period of temporary disability, as well as the stay of employees on leave, their dismissal on this basis was not allowed. 
3rd (1991 until present) - on March 20, 1991, the owner or his/her authorized body was given the right to terminate the employment contract with the heads of the enterprise in case of one-time gross breach of their work duties. Subsequently, this right became modern and extended to the heads of enterprises and their separate divisions, the heads, deputies, chief accountants, their deputies, as well as to the officials of the revenue and duties bodies nominated for special ranks, and officials of central executive bodies implementing national policy in public financial control and price control. A commission of guilty acts by the head of the enterprise as an independent ground for termination of the employment contract, as a result of which wages were paid late or in the amount lower than the statutory minimum wage, was singled out of one-time gross breach of work duties by this subject.

Legislation, statutes, and regulations on discipline continue to use the construction "one-time gross breach of work duties". Termination of the employment contract on this ground is carried out without the consent of the elected body of the primary trade union organization (trade union representative).

Labour disputes on the applications of the head of the enterprise and their deputies on dismissals are directly considered in the district (city) courts.

\subsection{Foreign experience of legal regulation of employee dismissal in case of one-time gross breach of work duties}

At the turn of the 80-90s of XX century, socioeconomic transformations in many countries in general, and especially in Europe, were focused on the actual implementation of democratic principles of society with 
a market economy. They caused an urgent need for the formation and development of independent, qualitatively new legal systems in each country ${ }^{1}$. Since the reform or modernization of any social object require its potential for positive development in its basic structure and exclude any disintegrating socio-cultural matter that has not withstood the test of time, most countries have chosen to modernize the inherited legal system, transformation of all its components and interrelations of the latter: legal culture, consciousness, ideology, legal science, legal policy, legal practice, etc. In almost all post-socialist States, the processes of democratic society transformation were aimed primarily at the formation of an economy with a developed labour market. An organic component of these reform processes was the formation of a qualitatively new for post-socialist societies legal regulation of labour and associated relations. This, in turn, required not only the improvement of inherited socialist legal systems or the quantitative replacement of legal regulations, but the adoption of conceptually new ones.

The deep and inevitable democratic transformations in Ukraine also pose a challenge of restructuring and significantly increasing the level of efficiency and quality of legal regulation of labour relations on their basis. Their successful implementation is impossible without taking into account the best foreign standards. At the present stage, the relevancy of the study in the field of comparative law is associated primarily with the expansion of international scientific contacts and the need to determine the patterns of development of national law concepts and provisions.

I. Sabo emphasises that the comparative method application in legal science is essential, because different legal systems affect each other. Analysis of such interaction

1 Tkáčová, D. Selected problems of banking restructuring in the Slovak Republic. BIATEC, no. 1, 1999: 8-10. 
enables to understand the development of both individual legal systems and individual sectors of law and legal institutions. According to the scientist, comparative law study cannot be considered an independent science, though it is theoretically oriented ${ }^{1}$. Comparative law study is not just a comparison of the legal systems of different states, but a study of the law development patterns of the latter, the determination of the general and special, common and opposite in these systems. An important task is to study the gradual progressive movement of legal provisions, which corresponds to their development patterns, as well as reverse progressive processes that act in opposition to these patterns.

According to S. S. Alekseev, the comparative legal method enables not only to identify opposites, differences and features of succession of legal systems of different historical types and legal families, but to formulate general theoretical positions and constructions, to emphasize patterns of their functioning and development that consider specificities of the systems of different social structures, epochs, countries ${ }^{2}$.

The Labour Code of the Republic of Belarus ${ }^{3}$ utilises the category of “one-time gross breach" in several cases. For example, in accordance with its paragraph 9 of Art. 42 an employment contract concluded for an indefinite period, as well as a fixed-term employment contract before its expiration may be terminated by the employer in the case of one-time gross breach by an employee of labour protection rules, causing injury or death of others. The legislator proceeds from the fact that the employee has not performed the duty

\footnotetext{
1 Sabo, I. Comparative Law. In Criticism of the modern bourgeois. theory of law. V. A. Tumanova (Ed.). M.: Progress, 1969: 165-207.

2 Alekseev, S. S. General theory of law. In 2 vols. Vol.1. M.: Yurid. lit., 1981. $359 \mathrm{p}$.

3 Labour Code of the Republic of Belarus (approved by Law of Resp. of Belarus No. 296-C of 26 July 1999). Nats. Reestr prav. actov Resp. Belarus, no. 80 (2/70), 1999.
} 
to comply with the requirements established by regulations on labour protection and safe work. According to Article 232 of this Code ("Duties of the employee on labour protection"), the employee is obliged:

- to comply with the requirements of labour protection, as well as the rules of conduct in the organization, in production, ancillary premises and staff facilities;

- to comply with the provisions and obligations of labour protections provided for in the collective agreement, contract, employment contract, job responsibilities and internal labour regulations;

- to correctly use the personal protective equipment provided to him, and in case of non-receipt immediately notify the direct supervisor;

- in the established manner to pass preliminary, periodic and extraordinary (during aggravation) medical examinations, preparation (training), retraining, internship, instruction, raising of professional skill and check of knowledge on labour protection;

- to assist and cooperate with the employer in ensuring healthy and safe working conditions, immediately notify his/ her immediate supervisor or other official of the employer about the malfunction of equipment, tools, devices, vehicles, protective equipment, aggravation;

- to immediately inform the employer of any situation that threatens the life and health of workers and others, of an accident that occurred at work, to assist the employer in taking measures to provide the necessary assistance to victims and deliver them to health facilities;

- to perform other duties prescribed by law on labour protection.

Breach of labour protection rules can be in the form of: non-compliance with the rules, improper compliance with them, the commission of actions expressly prohibited by the rules. According to the authors of the Commentary to the 
LC of the Republic of Belarus, assessment of the gravity of breach of labour protection rules should take into account: (a) the degree of the employee's guilt, (b) the presence of the victim's guilt, (c) the circumstances under which the breach was committed; (d) the obvious threat to the life and health of others. In this case, the employer should not take into account whether this breach is committed for the first time, whether the employee has been previously subject to disciplinary action, what is his marital status, etc. ${ }^{1}$.

According to para. 1 of Art. 47 of the LC under consideration, one of the additional grounds for termination of the employment contract at the initiative of the employer is one-time gross breach of work duties by the head of the organization (separate unit), his/her deputies, chief accountant and his/her deputies. According to Art. 46 of the Civil Code of this Republic ${ }^{2}$ organizations are considered legal entities. Moreover, it does not matter whether the legal entity is commercial or non-commercial. According to Art. 51 of this CC, separate units can be representative offices and suboffices. At least they are not legal entities but the legal entity that created them endow them with the relevant property and approve with the provisions to follow in their activity. Heads of representative offices and suboffices are appointed by the legal entity and act on the basis of its power of attorney.

While the construction "gross breach of work duties" is evaluative, some legal regulations contain rules for its use. For example, para. 2 of the Decree of the President of the Republic of Belarus "On granting legal entities a deferral of payment of arrears of taxes and penalties” No. 292

\footnotetext{
1 Glovanova, V. G., Semenkova, V. I. (Eds.). Commentary on the Labour Code of the Republic of Belarus: Article-by-article application of sample documents. Minsk: Dikta, 2009. 1328 p.

2 Civil Code of the Republic of Belarus (approved by Law of Republic of Belarus No. 218-C of 7 December 1998). Vedom. Nats. Sobr. Resp. Belarus, no. 7-9, 1999. Art. 101.
} 
of 13 August $1996^{1}$ contains the following prescription: "To prohibit from the date of entry into force of this Decree the accrual and payment of all types of bonuses to managers and chief specialists (their deputies) of legal entities that have arrears of payments to the budget, formed from 1 January 1996, until full repayment of arrears to the budget by these legal entities. To establish that non-compliance with this prohibition is gross breach of work duties by the head, chief accountant (their deputies) of the legal entity. In contracts concluded with the heads of legal entities, the employer is obliged to provide for the personal responsibility of the head for the breach of the prohibition..., including the termination by the employer of the contract before its expiration. To establish that the prohibition... does not apply to heads and chief specialists (their deputies) of legal entities, who in accordance with the decisions of the President of the Republic of Belarus, regional and Minsk City Councils are granted deferral (instalment) of repayment of arrears of payments to the budget, accrued economic sanctions and fines in case of timely ongoing payments to the budget."

Paragraph 5 of Decree of the President of the Republic of Belarus "On additional measures to improve labour relations, to strengthen labour and executive discipline" No. 291 of 26 July $1999^{2}$ enshrines, "To consider noncompliance with the Constitution of the Republic, Decisions of the President of the Republic of Belarus, laws of the Republic of Belarus, Resolutions of the Council of Ministers of the Republic of Belarus and court rulings in the performance of official duties as gross breach of work duties..

1 Decree of the President of the Republic of Belarus on granting legal entities a deferral of payment of arrears of taxes and penalties No. 292 of 13 August 1996. Collection of Presidential decrees and Resolutions the CM of the Republic of Belarus, no. 23, 1996. Art. 566.

2 Decree of the President of the Republic of Belarus on additional measures to improve labour relations, strengthen labor and executive discipline No. 29 of 26 July 26 1999. Nats. Reestr prav. actov Resp. Belarus, no. 58 (1/512), 1999. 
One-time gross breach of work duties as the ground for termination of the employment contract at the initiative of the employer

Decree of the President of the Republic of Belarus "On strengthening the requirements for managers and employees of organizations” No. 5 of 15 December $2014^{1}$ established that the heads of organizations under their personal responsibility are required to ensure:

- production and technological, executive and labour discipline;

- maintenance of production buildings (premises), equipment and devices in accordance with the established requirements;

- proper working conditions for employees; consolidation in job (work) instructions of employees taking into account the specifics of their job function duty to comply with technological regulations and standards for production (works, services), with production process requirements, manufacturing technology of goods (works, services), as well as cleanliness and tidiness in the organization and directly in the workplace.

Gross breach of work duties, which entail the unconditional disciplinary liability of the head of the organization, up through and including dismissal, is: (a) failure to comply with the above requirements; (b) concealment (substitution) of grounds for dismissal of the employee if there are grounds for his/her dismissal for committing guilty acts; (c) other unlawful actions (inactivity) of the head, established by law. Cases of gross breach of work duties also include the facts of failure to prevent damage, disclosure of State and official secrets, and others.

A. A. Voityk argues that breach of the rules of internal labour regulations by officials is not the considered ground for termination of the employment contract, but an independent basis for the application of disciplinary actions

\footnotetext{
1 Decree of the President of the Republic of Belarus on strengthening the requirements for managers and employees of organizations No. 5 of 15 December 2014. http://president.gov.by/ru/ official_documents_ru/view/ dekret-5-ot-15-dekabrja-2014-g-10434.
} 
to the employee ${ }^{1}$. According to para. 1 of Art. 47 of this LC, a dismissal of the employee is not a disciplinary action, and therefore the procedure and terms of bringing him/her to disciplinary liability in this case are not applied.

Another additional ground for dismissal of the head of the organization is his/her breaches of wage payment frequency and procedure without good reason and (or) assistance (para. 1 and 2 of Article 47 of the LC). Wage payment is required to be carried out frequently on the days specified in the collective agreement, contract or employment contract, but at least 2 times a month. Other wage payment frequency can be determined by law for certain categories of employees. If wage payment frequency coincides with weekends, public holidays, payment is required to be carried out the day before.

In the labour legislation of the Russian Federation, the construction under analysis is also used frequently. In particular, according to para. 6 of Art. 81 of the LC of the RF, an employment contract can be terminated at the initiative of the employer in cases of one-time gross breach by the employees of their work duties, such as:

a) truancy, i.e. his/her absence from the work without reasonable excuse throughout the working day (shift) regardless of its duration, as well as absence from work without reasonable excuse for a period longer than four consequent hours during a working day (shift);

b) appearing on working place (at his/her workplace or on the territory of the organization or facility, where on behalf of the employer he/she is required to perform employment function) in a state of alcoholic, narcotic or other intoxication;

c) disclosure of a secret (State, commercial, official etc.), protected by law, that has been learned by him/her because 784 p.

1 Semenkova, V. I. (Ed.). Labour Law. 3rd ed. Minsk: Amalfeia, 2006. 
of his/her performance of work duties, including personal data on another worker;

d) commission on working place of a theft (including minor theft), embezzlement or intentional damage or destruction of property, established as such under court verdict, entered in force, or decision of a judge, body, official, authorized to consider cases of administrative offenses;

e) worker's breach of labour protection regulations established by the commission or the commissioner for labour protection if this breach has coursed disastrous consequences (accident at work, accident, wreck, disaster) or could certainly lead to these consequences.

These grounds for dismissal can be applied to all categories of employees, regardless of their position or industry affiliation of the enterprise whereby they work.

One-time gross breach by the head of the organization (suboffice, representative office), his/her deputies of their work duties is the ground for termination of the employment contract at the initiative of the employer according to para. 10 of Art. 81 of the LC of the RF.

According to the authors of the Commentary to the LC of the RF edited by S. M. Baburin, these employees are on a special position in the enterprise in the organization: they are endowed with administrative functions to manage the labour organization, to ensure production technology and safety. Therefore, any one-time gross breach (nonfulfilment) by them of work duties can lead to negative effects for the company ${ }^{1}$.

The heads of other structural units (except suboffice, representative office) and their deputies, as well as the chief accountant of the organization may not be dismissed on the above grounds. However, the employment contract with

1 Baburina, S. N. (Ed.). Commentary to the Labour Code of the Russian Federation (article by article). Scientific and practical. With explanations from official bodies and article-by-article materials. 2nd ed. M.: Kn. mir, 2013. 848 p. 
them may be terminated for one-time gross breach by them of work duties in accordance with paragraph 6 of Art. 81 of this Code. According to para. 49 of the Resolution of the Plenum of the Supreme Court of the RF "On the application by the courts of the Russian Federation of the Labour Code of the Russian Federation” No. 2 of 17 March $2004^{1}$, the question of whether the breach is gross is decided by the court taking into account the specific circumstances of each case. At the same time, the employer is required to prove that it really occurred and was gross. Moreover, gross breach of work duties should also be considered as non-fulfilment by the above-mentioned persons of the obligations imposed on them by the employment contract, which could have caused damage to the health of employees or property damage to the organization. According to L. O. Chikanova, this can be breach of labour protection requirements, rules of register for tangible assets, statistical data garbling, excess of official authority or jobbery ${ }^{2}$.

A ground for a dismissal cannot be non-performance of any actions that were not the responsibility of the head of the organization (suboffice, representative office) or his/ her deputy.

A dismissal, under paragraph 10 of Art. 81 of the LC of the RF, is a disciplinary action, and therefore it is allowed no later than one month from the date of detection of a disciplinary misdemeanour without taking into account the time of illness of the employee and his/her leave. Such an action cannot be applied later than 6 months from the date of the misdemeanour, and according to the results of the examination, review of financial and economic activities or

\footnotetext{
1 Resolution of the Plenum of the Supreme Court of the RF on the application by the courts of the Russian Federation of the Labour Code of the Russian Federation No. 2 of 17 March 2004. Bul. Verkhov. Suda RF, no. 6. 2004. Art. 486.

2 Orlovskii, Yu. P. (Ed.). Commentary to the Labour Code of the Russian Federation. 5th ed. M.: Kontrakt: INFRA-M, 2011. 1456 p.
} 
audit, no later than two years from the date of its commission. These terms do not involve the time of criminal proceedings.

According to Art. 341 of the LC of the RF termination of work in the mission of the Russian Federation abroad occurs in connection with the expiration of the period established when sending an employee to the relevant federal executive body or public institution or when concluding a fixed-term employment contract with him/her.

In addition, service abroad can be terminated early in case of one-time gross breach by an employee of work duties or of the regime requirements known to him/her at the conclusion of the employment contract. The possibility of a dismissal for one-time gross breach of work duties by certain categories of employees is provided for by the special legislation. For example, according to Art. 4 of the Statute on discipline of employees of organizations operating particularly radiation-hazardous and nuclear-hazardous production and facilities in the field of atomic energy use, approved by the Federal Law of the Russian Federation of 8 March $2011^{1}$, a disciplinary misdemeanour, i.e. failure or improper performance for reasons attributable to the employee of the operating organization of the labour (official) duties assigned to him/her, the employer, entails along with the disciplinary actions provided for by the LC of the RF, application of disciplinary actions, such as: (a) severe reprimand, (b) professional impropriety notice, (c) termination of the employment contract for onetime commission of one of the breaches provided for in Art. 61 of the Federal Law "On the use of atomic energy" of November 21, $1995^{2}$, if the effects of this breach threaten

1 Statute on discipline of employees of organizations operating particularly radiation-hazardous and nuclear-hazardous production and facilities in the field of atomic energy use (approved by Federal Law of the RF No. 35-FZ of 8 March 2011. Collection of FR Legislation, no. 11, 2011. Art. 1504.

2 Federal Law on the use of atomic energy No. 170-FZ of 21 November 1995. Collection of FR Legislation, no. 48, 1995. Art. 4552. 
the safe function of the operating organization and endanger the life and health of citizens and the environment.

These breaches are:

- breach of provisions and rules in the field of atomic energy use;

- breach of the terms and conditions of permits (licenses) for the right to conduct work in the field;

- failure or improper performance of instructions of State safety regulatory authorities;

- carrying out works at a nuclear installation, at a radiation source and at a storage point, as well as handling nuclear materials and radioactive substances without the specified permit;

- non-compliance with the requirements for the location of the nuclear installation, radiation source and storage point of such materials and substances;

- delivery, installation and commissioning of faulty equipment of the nuclear installation, radiation source and storage point;

- non-fulfilment of their official duties by employees of the nuclear installation, radiation source and storage point;

- quitting on their own of a nuclear installation, radiation source or storage point by the workers from the shift on duty;

- non-fulfilment of their official duties by the persons in critical situations which has entailed or could have entailed human victims, the unwarranted irradiation or the radioactive contamination of the environment;

- access to the work in a nuclear installation, radiation source or storage point of the workers without relevant documents certifying the skill of the workers with medical contra-indications for the work in said facilities, and also of the persons below 18 years of age;

- direct or indirect compulsion of workers by the officials to breach the regulations and instructions on the 
One-time gross breach of work duties as the ground for termination

of the employment contract at the initiative of the employer

operation of a nuclear installation, radiation source or storage point;

- evasion of officials and other workers from the discharge of their duties according to the applicable plan for the protection of the workers engaged in the facilities using atomic energy and of the population in cases of accidents;

- sending by the official of the workers employed in the facilities using atomic energy to the dangerous radiation zones with the possible excess of the dose limits and the admissible levels of radiation without the consent of said workers and without informing them about the possible levels of irradiation, and also with breach of the standards, rules and instructions provided for these conditions;

- unjustified or intentional release or discharge of radioactive substances to the atmosphere, water or subsoil in quantities exceeding the maximally admissible levels;

- concealment of an accident or breach of the procedure for informing about the accident in the nuclear installation, radiation source or the storage point;

- the concealment of information about the radiation contamination of the environment, as well as the issue of deliberately false information about the radiation situation in the said facilities;

- breach of the existing order of accounting and control of nuclear and radioactive substances;

- participation in the organization and conduct of nonsanctioned public arrangements in the territory of a nuclear installation, radiation source or storage point, etc.

Article 86 of the Labour Code of the Republic of Moldova ${ }^{1}$ recognizes one-time gross breach of official powers by the head of the enterprise, his/her deputies or the chief accountant as a special ground for dismissal. As a general rule, the employer is required to notify the employee by the

1 Labour Code of the Republic of Moldova (approved by Law of Republic of Moldova No. 154 of 28 March 2003). Monitorul Oficial, no. 159-162, 2003. 
order (regulation, decision, resolution) under the receipt of his/her intention to terminate an individual employment contract concluded for a definite or indefinite period, within the time limits prescribed by law. However, upon termination of an individual employment contract on the grounds under consideration, notification is not required. It should be noted that this Code allows the employer to terminate the employment contract with employees due to a change of ownership. In this case, the new owner not later than within three months from the date of ownership, has the right to terminate the individual employment contract concluded with the head of the enterprise, his/her deputies, the chief accountant. The new owner pays the persons discharged additional compensation, if it is provided by the individual employment contract.

According to Art. 43 "Additional grounds for termination of employment contract with certain categories of employees" of the Labour Code of Turkmenistan, an employment contract can be terminated in case of one-time gross breach of work duties by the head of the enterprise (unit), his/her deputies and employees who are disciplinary liable according to the Statute of the latter.

According to Art. 235 of the Labour Code of the Republic of Lithuania $^{1}$, gross breach of work duties is a disciplinary misdemeanour, which grossly violates the provisions of laws and other legal regulations that directly regulate the work of the employee, or a gross deviation from work duties or the established work schedule. Gross breaches of work duties are:

- inadmissible treatment of visitors or interested parties or other actions that directly breach constitutional human rights;

1 Labour Code of the Republic of Lithuania (approved by Law of Republic of Lithuania No. IX-926 of 4 June 2002). http://www.vbfondas.lt/upload/LR darbo_kodeksas.htm. 
- disclosure of state, official, commercial or technological secrets or informing to a competing enterprise;

- participation in activities that in accordance with the provisions of laws, other regulations, rules of labour regulations, collective or employment agreements are not consistent with the employment function of the employee;

- jobbery in order to obtain illegal income for themselves or others, for other personal reasons, as well as arbitrariness and bureaucracy;

- breach of equality between men and women or sexual harassment in relation to interested parties or subordinates;

- refusal to provide information when laws, other legal regulations or rules of labour regulations require to provide it, or provision in such cases of knowingly false information;

- acts with aspects of theft, fraud, misappropriation or embezzlement of property, unlawful receipt of wages, although for them the employee has not been prosecuted or administratively liable;

- appearing during working hours on working place in a state of alcoholic, narcotic or other intoxication, except in cases when intoxication has been caused by production processes taking place at the enterprise;

- absence from work without good reason throughout the working day (shifts);

- refusal from health check, when it is mandatory for the employee;

- other misdemeanours, which grossly breach the work schedule.

The Labour Code of the Czech Republic ${ }^{1}$ does not use a wording "one-time gross breach of work duties" but has Chapter 10 "Resignation or dismissal from a managerial

1 Shugaev, A. A., Kisterev, D. D. Labour Codes of the Czech Republic and the Russian Federation: Comparative legal analysis. M.: RITS ISPI RAN, 2010. $344 \mathrm{p}$. 
position”. The head of a State department can be dismissed from office by a person (body) authorized to do so by a legal regulation, and the head of an office of a State department can be dismissed only by the head of the department or an authorized body.

If the employer is a legal or natural person, this employer can simply agree with his/her employee who holds a managerial position on the need to dismiss him, provided that the parties agree at the same time that this employee can resign him/herself. The term "managerial position" in this case means: (a) a position directly subordinate to the governing body provided for by the Statute, if the employer is a legal entity, the employer, if it is a natural person; (b) a position directly subordinate to a member of senior management, if the employer is a legal entity and provided that the lower-level manager is subordinate to the person holding that senior position.

If the employer is a legal entity, the employee holding managerial position can be dismissed only by the governing body specified in the Statute; and if he/she is a natural person, the manager may be dismissed only by that person-employer.

The notice of termination or statement of resignation shall be made in writing and delivered to other party, otherwise they will be considered invalid. An employee's term of office ends the day after such notice or statement is delivered to the other party, unless they specify a later date.

In the countries of the Anglo-Saxon law (USA, Great Britain, Ireland, Canada, New Zealand) the head of the enterprise is not considered as an employee. He/she is outside the scope of labour law and performs his/her functions on the basis of a contract of a civil nature. I. Ya. Kiseliov argues that in the Western countries the contract with managers is labour one, because it is characterized by such features as timeliness, written form, features of determining the job 
function, simplified dismissal (especially in connection with loss of confidence, reaching the age limit) etc. ${ }^{1}$.

However, the scientist's arguments concern only the management of the organization of the middle and lower echelons. In 1963 Decision of the Court of Appeal of Great Britain states that the president, vice-president, director, executive director of the company are not employees. The labour courts of this State consider cases of unlawful dismissal only in respect of secondary management personnel. It makes sense to agree with $\mathrm{M}$. V. Demidov that the essence of the relationship between senior management and the employer corresponds rather to the construction of civil representation ${ }^{2}$. According to O. H. Sereda, a legal entity as a supra-personal entity that realizes its rights and responsibilities through a mediation of a number of persons whose actions, by virtue of law and the constituent documents, are considered as actions of the organization itself $^{3}$. As a result, the use of the term "dismissal” in relation to such subjects is inappropriate. Termination of employment occurs at the discretion of the owner of the organization on the grounds specified in the civil contract.

The results of a comprehensive study in this sub-section of the monograph enable to make conclusions of significant theoretical and applied significance.

1. In the world two key approaches to the legal regulation of labour activity of the head of the organization: (a) in the countries of the Anglo-Saxon law the head is not considered as an employee, but is outside the scope of labour law and performs his/her functions on the basis of a contract

1 Kiselev, I. Ya. Comparative and international labor law. M.: Delo, 1999. $728 \mathrm{p}$.

2 Demidov, N. V. Dismissal on the initiative of the employer. Ph.D.'s thesis. Tomsk State Ped. Un-ty. Tomsk, 2009. 229 p.

3 Sereda, O. H. Employer as a subject of labor law. Ph.D.'s thesis. Yaroslav Mudryi National Law University. - Kh., 2004. 210 p. 
of a civil nature. As a result, the use of the labour law term "dismissal" in relation to such subjects is inappropriate. Termination of employment relationship occurs at the discretion of the owner of the organization on the grounds specified in the civil contract; (b) in the countries of the continental law the head, considering the work function he/ she performs and duties assigned to him/her, has the status of an employee, though specific.

2. If the head of the organization is considered as a subject of labour law, the possibility of this dismissal in case of one-time gross breach of work duties is provided for either by (a) provisions of the Labour Code of the country and other legal regulations containing provisions of labour law (post-Soviet states), or (b) the terms and conditions of the individual employment contract (Bulgaria, Estonia, Latvia, Germany, the Czech Republic and others).

3. The labour legislation of foreign countries recognizes mainly the head of the organization and his/her deputies as the subject of termination of the employment contract at the initiative of the employer in case of one-time gross breach of work duties. Occasionally, they include the heads of separate structural units (their deputies), chief accountants (their deputies), employees covered by statutes and regulations on discipline.

4. Although the construction "gross breach of work duties" is evaluative and remains at the discretion of the court, employer or other law applier, legal regulations or individual employment contracts often provides for interpretations of its use. The grounds for dismissal cannot be non-performance of any actions, which are not duties of the subjects of dismissal.

5. Dismissal on the grounds under consideration is a disciplinary action, therefore, the legal provisions regarding the procedure and terms of bringing a guilty person to disciplinary liability should be complied with. 
If (as a general rule) the employer is obliged to notify the employee by order (directive, decision, resolution) under the receipt of his/her intention to terminate the individual employment contract within the period prescribed by law, termination of the employment contract on the grounds of notification is not required. Severance pay or any other pecuniary compensation is not paid to the dismissed person. In addition, the employer does not have any responsibilities for his/her employment.

\section{Conclusions to Chapter 2}

The comparative study of the legal regulation of termination of the employment contract in case of onetime gross breach of work duties by a worker enabled to make certain scientific and theoretical conclusions and formulate proposals as follows:

1. The factory law regarded the manager (administrator) as a fairly independent figure. For example, fines for breach of this law were levied on him personally, and only when the manager did not pay the fine for 2 weeks, the penalty was sent to the owner. The latter's right to dismiss the manager was not limited by law, as the agreement between him and the manager was considered civil. The regulation of the labour activity of the manager as an employee is not reflected in law. Wherever employment, working conditions, dismissal, etc. are revealed, only workers are mentioned.

2. The formation and development of legal regulation of the termination of the employment contract in case of worker's one-time gross breach of work duties includes the periods as follows:

The 1st (1928-1969) - the stated ground for dismissal is launched for managers and other decision makers, taking into account the nature of their work function. The 
lists of decision makers were initially established by the People's Labour Commissariats of the USSR and the Union Republics upon the approval of the All-Union Central Council of Trade Unions and the Republican Soviet of Trade Unions, and later by the Presidium of the Verkhovna Rada or the Council of Ministers. At different times, these employees include not only the heads of enterprises, their deputies and assistants, chief engineers, chief physicians, chief accountants, heads of workshops, masters, construction site supervisors, also but prosecutors and investigators; teaching staff of higher educational institutions and employees of research institutions, elected employees, instructors, inspectors, managers of trade union departments; artists and other creative workers. In the 60s of the twentieth century, dismissals for one-time gross breach were applied to certain categories of employees, subject to the regulations and statutes on discipline (railway workers, workers and employees of the coal industry).

The dismissal did not become an obstacle to the prosecution of a guilty person regarding the same breach. It could be appealed in the chain of command directly to the next higher authority or a higher official. All decisions on complaints were considered final and reviewed only under the supervision by the next higher authority.

The 2nd (1970-1990) - for the first time, the Principles of Labour Legislation of the USSR and the Union Republics and in the LC of the USSR provide for one-time gross breach of work duties by employee, subject to disciplinary liability in the chain of command, as a separate special ground for their dismissal. The categories of employees, subject to disciplinary liability in the chain of command were determined by the special List, approved by the Presidium of the Supreme Council of the USSR. Compared to the previous period, this List additionally included employees with diplomatic ranks, as well as diplomatic couriers, referents of the 
Ministry of Foreign Affairs of the USSR, employees of public organizations, approved for the position by a collegial body; employees of the Main Customs Department of the Ministry of Foreign Trade of the USSR and other customs institutions of the USSR who have personal ranks, employees of the Main Department for Foreign Tourism, inspectors and engineers-inspectors of the bodies of the State Mining and Technical Supervision, etc. However, teaching staff of higher educational institutions and employees of research institutions, as well as artists and other creative workers are excluded from the scope of these legal regulation provisions.

The current LC, together with the category under study, provides for the term "explicit breach of law." An official guilty of unlawful dismissal of an employee with explicit breach of law is required to compensate the damage caused to the enterprise, institution, in connection with payment for the period of forced truancy. The explicit breach of law was dismissal of: (a) an employee without the consent of the trade union committee or on grounds not provided by law; (b) a people's deputy without the consent of the relevant Council, and between sessions, of the Executive Committee of the Council of People's Deputies or the Presidium of the Verkhovna Rada; (c) the head of the people's control group of the enterprise without the consent of the district, city, district in the city committee of people's control; (d) women in cases provided by law, when the administration was aware of the existence of circumstances that preclude the possibility of their dismissal; (d) workers and officials under the age of 18 without the consent of the district (city) commission on underage persons.

In the 70's and 80's of the twentieth century, much more sectors of the national economy adopted Statutes on discipline. The latter provided for that the special ground for termination of the employment contract was committing gross breach of work duties. This ground concerns 
employees of the State Customs Control, workers employed in particularly dangerous underground conditions, employees of the Ministry of Atomic Energy, workers and employees of ships supporting the navy, etc. During the period of temporary disability, as well as the stay of employees on leave, their dismissal on this basis was not allowed.

The 3rd (1991 until present) - on March 20, 1991, the owner or his/her authorized body was given the right to terminate the employment contract with the heads of the enterprise in case of one-time gross breach of their work duties. Subsequently, this right became modern and extended to the heads of enterprises and their separate divisions, the heads, deputies, chief accountants, their deputies, as well as to the officials of the revenue and duties bodies nominated for special ranks, and officials of central executive bodies implementing national policy in public financial control and price control. A commission of guilty acts by the head of the enterprise as an independent ground for termination of the employment contract, as a result of which wages were paid late or in the amount lower than the statutory minimum wage, was singled out of one-time gross breach of work duties by this subject.

Legislation, statutes, and regulations on discipline continue to use the construction "one-time gross breach of work duties". Termination of the employment contract on this ground is carried out without the consent of the elected body of the primary trade union organization (trade union representative).

Labour disputes on the applications of the head of the enterprise and their deputies on dismissals are directly considered in the district (city) courts.

3. In the world two key approaches to the legal regulation of labour activity of the head of the organization: (a) in the countries of the Anglo-Saxon law the head is not considered as an employee, but is outside the scope of labour 
law and performs his/her functions on the basis of a contract of a civil nature. As a result, the use of the labour law term "dismissal" in relation to such subjects is inappropriate. Termination of employment relationship occurs at the discretion of the owner of the organization on the grounds specified in the civil contract; (b) in the countries of the continental law the head, considering the work function he/ she performs and duties assigned to him/her, has the status of an employee, though specific.

4. If the head of the organization is considered as a subject of labour law, the possibility of this dismissal in case of one-time gross breach of work duties is provided for either by (a) provisions of the Labour Code of the country and other legal regulations containing provisions of labour law (post-Soviet states), or (b) the terms and conditions of the individual employment contract (Bulgaria, Estonia, Latvia, Germany, the Czech Republic and others).

5. The labour legislation of foreign countries recognizes mainly the head of the organization and his/her deputies as the subject of termination of the employment contract at the initiative of the employer in case of one-time gross breach of work duties. Occasionally, they include the heads of separate structural units (their deputies), chief accountants (their deputies), employees covered by statutes and regulations on discipline.

6. Although the construction "gross breach of work duties" is evaluative and remains at the discretion of the court, employer or other law applier, legal regulations or individual employment contracts often provides for interpretations of its use. The grounds for dismissal cannot be non-performance of any actions, which are not duties of the subjects of dismissal.

7. Dismissal on the grounds under consideration is a disciplinary action, therefore, the legal provisions regarding the procedure and terms of bringing a guilty 
person to disciplinary liability should be complied with. If (as a general rule) the employer is obliged to notify the employee by order (directive, decision, resolution) under the receipt of his/her intention to terminate the individual employment contract within the period prescribed by law, termination of the employment contract on the grounds of notification is not required. Severance pay or any other pecuniary compensation is not paid to the dismissed person. In addition, the employer does not have any responsibilities for his/her employment. 


\section{CHAPTER 3. LEGAL REGULATION OF EMPLOYMENT CONTRACT TERMINATION IN CASE OF ONE-TIME GROSS BREACH OF WORK DUTIES IN UKRAINE: CURRENT STATE OF AFFAIRS AND AREAS OF IMPROVEMENT}

\subsection{Subjects of Dismissal in case of One-time Gross Breach of Work Duties}

In labour law doctrine, the concept of "legal person" is one of the most important. It is traditional to define a legal person as a party to a legal relationship, a rights-holder and duty-bearer. The construction "holder of rights-holder and duty-bearer" covers individuals and legal entities. N. M. Onishchenko believes that a legal person is a person or organization by which the state recognizes the ability to be holders of subjective rights and legal obligations ${ }^{1}$. According to V. Yu. Urkevych, the categories "legal person" and "participant in legal relationship" are correlated as a whole and part, therefore, the participant in legal relationship is a person who has all the characteristics of a legal person, certain rights and obligations that arise as an effect of these legal relations ${ }^{2}$.

1 Zaichuk, O. V., Onishchenko, N. M. (Eds.). Theory of State and Law. K.: Jurinkom Inter, 2006. 688 p.

2 Urkevych, V. Yu. Agrarian legal relations in Ukraine. Extended abstract of Doctor's thesis. Yaroslav Mudryi National Law University. Kh., 2007. 39 p. 
Subjects of labour law are a required element of labour and associated legal relations.

In accordance with para. 1 of Art. 41 the LC of Ukraine the participant in legal relationship arising from termination of the employment contract at the initiative of the employer in the case of one-time gross breach of work duties, are the heads of enterprises, institutions, organizations of all forms of ownership (suboffice, representative office, branch, other separate division), their deputies, chief accountants, their deputies, as well as officials of revenue and duties bodies nominated for special ranks and officials of central executive bodies implementing national policy in public financial control and price control.

The importance of a clear and unambiguous understanding of the law application body of the participant in the legal relationship in question is confirmed by an example from case law.

On 12 February 2008, N. was appointed to the position of the Doctor-in-Charge of Department No. 1 of the Public Institution "Polyclinic No. 2" of the Public Affair Administration. On 9 July 2010, the Chief Physician of the State Institution K. issued Order No. 54 on the dismissal of the Doctor-in-Charge $\mathrm{N}$. for one-time gross breach of work duties (para. 1 of Art. 41 of the LC of Ukraine). By order of the Chief Physician No. 174-k of 25 August 2010 N. was dismissed on that ground from 25 August 2010, since she had been on the sick leave, accordingly, the actual day of her dismissal was the first day of her return to work.

On 22 September 2010, N. filed a lawsuit to the Shevchenkivskyi District Court of Kyiv against the State Institution "Polyclinic No. 2" of the State Affairs Administration on reinstatement at work, recovery of average earnings during forced truancy and compensation for non-pecuniary damage. 
Satisfying the lawsuit, the court of first instance, with which the appellate court agreed, concluded that in accordance with para. 1.1 of the Regulation on Department No. 1 of the Public Institution "Polyclinic No. 2" of the Public Affair Administration (PAA) this Department is a structural subdivision of the specified institution. Paragraph 1.2 of this Regulation stipulates that the issue of economic activity in the Department No. 1 is decided by the management of the polyclinic on behalf of the deputy head of the PAA, therefore, Department No. 1 is a structural subdivision that does not take part in the management of the institution, in particular, in the management of its administrative and economic activities, therefore, N. is not engaged in the governing bodies of the health institution, hence her dismissal under para. 1 of Art. 41 the LC of Ukraine is groundless.

However, according to the panel of judges of the Judicial Chamber for Civil Cases of the High Specialized Court of Ukraine for Civil and Criminal Cases, this conclusion is erroneous. In accordance with para. 1 of Art. 41 the LC of Ukraine, an employment contract may be terminated on the initiative of the owner or his/her authorized body can be terminated in case of one-time gross breach of work duties the heads of enterprises, institutions, organizations of all forms of ownership (suboffice, representative office, branch, other separate division). If the head of enterprise is always the head of the legal entity, the head of a suboffice, representative office, branch, other separate division, can be the head of a subdivision without a legal status, but according to the scope of powers, he/she (the head) performs organizational and administrative functions, is responsible for the work of the structural subdivision.

Accordingly, in the consideration of the lawsuit for unlawful recognition of the order to dismiss a person under para. 1 of Art. 41 the LC of Ukraine, the court is required to establish whether a person has been the head of enterprise, 
institution, organization of all forms of ownership or suboffice, representative office, branch, other separate division, as well as whether he/she has committed one-time gross breach of work duties. Furthermore, in considering whether the head is the person with whom the employment contract can be terminated, according to Part 1 of Art. 41 the LC of Ukraine, both property and territorial separation of the structural unit, headed by him/her, should be taken into account, as well as take into account that the general provisions on the organizational structure of the enterprise, provided for in Art. 64 of the Economic Code of Ukraine, the enterprise has the right to create a suboffice, representative office, branch, other separate division, agreeing on the placement of the latter with the relevant local governments in the manner prescribed by law. These separate subdivisions do not have the status of a legal entity and operate on the basis of the regulations on them approved by the enterprise. Therefore, the persons who head such divisions have the status of the head of a separate division, which performs organizational and administrative functions.

It is established that according to the Regulations on Department No. 1, the latter is a structural division of the State Institution "Polyclinic No. 2". The Job Description of the Doctor-in-Charge of the Department No. 1 determines that he/she manages this Department, organizes its treatment-and-prophylactic and administrative-economic activity. Paragraphs 2.7 and 2.13 of the Job Description stipulates that the Doctor-in-Charge controls the provision of proper sanitary and hygienic conditions for department operation and is responsible for the state of its work and the level of medical care for patients. The Doctor-in-Charge is responsible for improper performance of functional duties provided by the Regulation on Department No. 1. The content and scope of functional duties of Doctorin-Charge, provided by the Regulations of Department 
No. 1 and the Job Description, gives reason to argue that the Doctor-in-Charge of Department No. 1 is the head of a separate division, who has performed organizational and administrative functions ${ }^{1}$.

Paragraph 1 of Art. 41 of the of Ukraine regarding officials of revenue and duties bodies nominated for special ranks, as subjects, covered by this ground for dismissal, requires clarification. Since, on 21 May 2014, the Cabinet of Ministers of Ukraine decided to establish the State Fiscal Service of Ukraine (SFSU) as a central executive body, directed and coordinated by the Cabinet of Ministers, having reorganized the Ministry of Revenue and Duties of Ukraine by transformingit ${ }^{2}$. This body, the body of revenue and duties, is now included in the Classification of Public Administration ${ }^{3}$.

The separation of service in the SFSU as an independent type of public service is logical, because it enables proper implementation of the key areas of public policy on national security in the economic sector, provided by Art. 8 of the Law of Ukraine "On Fundamentals of National Security of Ukraine” ${ }^{4}$, such as:

- creating favourable conditions for sustainable economic growth and a more competitive national economy;

- fast-tracking of innovative infrastructural and institutional change in the economy, improving the

1 On reinstatement at work, recovery of the average salary during forced truancy, compensation of non-pecuniary damage (case no. 6-3105sk11). http://reyestr.court.gov.ua/

2 Resolution of the CMU on establishment of the State Fiscal Service of Ukraine No. 160 of 21 May 2014. Ofitsiinyi visnyk Ukrainy, no. 46, 2014. Art. 1213.

3 Order of the State Statistics Service of Ukraine on approval of the Classification of Public Administration No. 143 of 07 May 2013. http://zakon.nau.ua/doc/?uid=1157. 2162.0.

4 Law of Ukraine on fundamentals of National Security of Ukraine No. 964-IV of 19 June 2003. Vidomosti Verkhovnoi Rady Ukrainy, no. 39, 2003. Art. 351. 
One-time gross breach of work duties as the ground for termination of the employment contract at the initiative of the employer

investment climate and increasing the effectiveness of investment processes;

- stimulating development for scientific high-tech industries;

- overcoming "shadow" economy by reforming the tax system, enhancing finance and investment as well as restraining international capital outflow, reducing unquantifiable extra-bank cash circulation;

- providing budget development, an internal and external currency protection, its stability, protection for investor's interests and financial markets.

According to the Regulation on the State Fiscal Service of Ukraine, approved by the Resolution of the Cabinet of Ministers of Ukraine No. 236 of 21 May 2014 ${ }^{1}$, SFSU is a central executive body, thereof activities are directed and coordinated by the Cabinet of Ministers of Ukraine.

The key missions of SFSU include:

- implementation of national policy: (a) in taxation; (b) in the field of state customs; (c) in counteracting offenses in the application of tax and customs laws and the exercise within the statutory powers of control over the receipt of taxes and duties, customs and other payments to budgets and state trust funds; (d) in the field of control over the production and circulation of alcohol, alcoholic beverages and tobacco products; (e) in administering the single contribution, as well as countering offenses in the application of the legislation on the payment of the single contribution; (f) regarding control over the timeliness of settlements in foreign currency within the period prescribed by law; compliance with the procedure for cash payments for goods (services); as well as the availability of licenses to conduct business activities subject to licensing in accordance with the law and trade patents;

\footnotetext{
1 Resolution of the CMU on the Regulation on the State Fiscal Service of Ukraine No. 236 of 21 May 2014 p. Ofitsiinyi visnyk Ukrainy, no. 55, 2014. Art. 1507.
} 
One-time gross breach of work duties as the ground for termination of the employment contract at the initiative of the employer

- submission to the Minister of Finance of Ukraine of proposals regarding the formation of: national policy: (a) in taxation; (b) in the field of state customs; (c) in counteracting offenses in the application of tax and customs laws and in the control over the receipt of taxes and duties, customs and other payments to budgets and state trust funds; (d) in the field of control over the production and circulation of alcohol, alcoholic beverages and tobacco products; (e) regarding control over the timeliness of settlements in foreign currency within the period prescribed by law; compliance with the procedure for cash payments for goods (services); as well as the availability of licenses to conduct business activities subject to licensing in accordance with the law and trade patents.

Resolution of the Cabinet of Ministers of Ukraine No. 311 of 6 August $2014^{1}$ provided for formation by legal entities of public law territorial bodies of the State Fiscal Service of Ukraine, as well as reorganization of the territorial bodies of the Ministry of Revenue and Duties of Ukraine by joining the relevant territorial bodies of the SFSU. The SFSU exercises its powers directly and through territorial bodies, duly established. In this service and in its territorial bodies, divisions of tax militia act.

At the same time, the current legislation continues to utilise the category of "revenue and duties".

The staff of revenue and duties is a set of employees, who on the basis of the employment contract perform their assigned work duties in the bodies of the State Fiscal Service of Ukraine, and includes: officials, tax militia, academic teaching and academic staff of educational institutions and scientific institutions, administrative technical staff and service staff.

1 Resolution of the CMU on the formation of territorial bodies of the State Fiscal Service and the recognition of some acts of the Cabinet of Ministers of Ukraine as repealed No. 311 of 6 August 2014. Ofitsiinyi visnyk Ukrainy, no. 64, 2014. Art.1765. 
An attempt to legally define the category of "revenue and duties officials" is in Part 1 of Art. 569 of the Customs Code of Ukraine ${ }^{1}$ : "The employees of the revenue and duties authorities responsible for achieving the objectives referred to in Article 544 of the Code, ensuring organisational, legal, human resources, finance, logistics support of the activities of such authorities shall be their officials. The revenue and duties officials shall be public servants."

According to A. M. Arhunova, this definition cannot be considered successful, because it does not provide a complete picture of this category of employees of the bodies in question: it is unclear who can apply for the relevant positions, what are the requirements for these employees, as well as these persons' status is vague. She argues that an official of revenue and duties bodies is a citizen of Ukraine who holds a full-time position in one of the revenue and duties bodies, has taken the Oath of Public Servant, has received a special title, which is paid from the State Budget of Ukraine, and according to the law is responsible for direct achieving of the objectives of revenue and duties bodies, ensuring organisational, legal, human resources, finance, logistics support of the activities of such authorities. According to the scientist, the essential features of revenue and duties officials are: a) citizenship of Ukraine; b) holding a full-time position in one of these bodies; c) taking the Oath of a public servant; d) ability to perform the missions assigned to the bodies of revenue and duties, and job responsibilities assigned to these persons, according to age, educational and qualification level, health, work experience, business and moral qualities; e) the legal status of these persons is determined by the Tax and Customs Codes of Ukraine, and in the part unregulated by them, by the Law of Ukraine “On Public Service”, the LC of Ukraine

1 Customs Code of Ukraine (approved by Law of Ukraine No. 4495-VI of 13 March 2012) Vidomosti Verkhovnoi Rady Ukrainy, no. 44-48. 2012. Art. 552. 
and other legal regulations; f) performance by a person of his/her official duties in the best interests of the State and on its behalf, control of the activity of this official by the State and in cases of coercion applied to him/her by law; g) restrictions related to the admission and service in these bodies; h) nomination of a special rank; i) remuneration of the official from the State Budget of Ukraine ${ }^{1}$.

According to para. 1 of Art. 41 the LC of Ukraine, another subject of one-time gross breach of work duties is an official of the central executive body that implements national policy in the field of public financial control.

The authors of the integrated training and certification complex State financial control: Review and audit recognize financial control as a method of management function of the State, involving: a) consolidation of legal provisions establishing the procedure for the use of financial resources by business entities; b) monitoring or other control actions for compliance with these provisions; c) detection of offenses in the use of financial resources and their elimination; d) blocking of unlawful financial transactions and taking actions to compensate for losses caused to the State by business entities and citizens ${ }^{2}$. Public financial control is one of the most important functions of public administration, aimed at identifying deviations from the accepted standards of legality, expediency and efficiency of management of finances and other public property, and in the presence of such deviations, at the timely appropriate corrective and preventive actions.

O. P. Pashchenko argues that the key features of financial control is that this activity: a) is associated with the use

1 Argunova, A. M. Legal regulation of labor relations of officials of revenue and duties. Ph.D.'s thesis. Scientific Institute of Legal Framework for Innovation Development of NALS of Ukraine. Kh., 2014. 219 p.

2 Hermanchuk, P. K. Stefaniuk, I. B., Ruban, N. I. et al. State financial control: Review and audit. K.: NVP AVT, 2004. 424 p. 
of financial control powers granted to financial control bodies to verify compliance with financial and legal provisions, and in case of offenses, with the application of appropriate actions; (b) is carried out by authorized state bodies; (c) is related to operating with provisions of law, resulting into documentation; (d) is aimed at creating appropriate conditions for financial control by the relevant entities; (e) is conducted using appropriate methods, means and techniques; (e) is a set of ordered control actions at certain stages; $(\mathrm{g})$ within limits thereof the powers of the financial control bodies are exercised ${ }^{1}$.

The State Financial Inspectorate of Ukraine (SFIU) is the central executive body, thereof activities are directed and coordinated by the Cabinet of Ministers of Ukraine through the Minister of Finance of Ukraine, which is part of the system of executive bodies and ensures the implementation of national policy in the field of public financial control. According to item 1 of Decree of the President of Ukraine No. 499/2011 "On Regulations on the State Financial Inspection of Ukraine” of 23 April 2011², this department replaced the Main Control and Audit Department of Ukraine. A. O. Mukhataiev emphasizes that the reform of the financial control system is not only of important socio-economic significance, but also of a primary importance in the formation of a democratic society. The reform of the system of state financial control began almost simultaneously with the processes of economic transformation, recovery of components of the State system. Nevertheless, such reform may not lead to the desired results, the creation of a holistic system of financial control, due to the fact that in this process

1 Pashchenko, O. P. Legal regulation of the process of financial control (according to the legislation of Ukraine). Ph.D.'s thesis. Nat. Acad. of State Tax. Services of Ukraine. Irpen, 2005. 210 p.

2 Decree of the President of Ukraine on Regulations on the State Financial Inspection of Ukraine No. 499/2011 of 23 April 2011. Ofitsiinyi visnyk Ukrainy, no. 2011. No. 31. Art. 1325. 
lacks a clear strategy, which should be based on a carefully thought-out concept ${ }^{1}$.

The key objectives of the SFI of Ukraine are the implementation of state financial control over: (a) the use and preservation of public financial resources, noncurrent assets and other assets; (b) the correctness of the determination of the need for budgetary funds and commitments; (c) efficient use of funds and property; (d) the state and reliability of accounting and financial reporting in ministries and other executive bodies, public funds, funds of compulsory state social insurance, budgetary institutions and economic entities of the public economic sector, as well as in enterprises, institutions and organizations that receive (received in the period under review) funds from the budgets of all levels, public funds and funds of compulsory state social insurance or use (used in the period under review) public or municipal property; (e) compliance with the law at all stages of the budget process regarding state and local budgets; (e) compliance with public procurement legislation; (g) the activities of business entities, regardless of the form of ownership, which are not referred by law to the controlled institutions; (h) a court decision rendered in criminal proceedings (Art. 2 of the Law of Ukraine "On Basic Principles of State Financial Control Realization in Ukraine” ${ }^{2}$ ).

The State Financial Inspection of Ukraine exercises its powers directly and through territorial bodies in the ARC, oblasts, cities of Kyiv and Sevastopol, districts, cities through inter-district, territorial bodies united in districts and cities or through chief inspectors in districts and cities.

1 Mukhataiev, A. A. Legal status and legislative principles of State Financial Inspection in Ukraine. Ph.D.'s thesis. Yaroslav Mudryi National Law University. Kh., 2005. 194 p.

2 Law of Ukraine on Basic Principles of State Financial Control Realization in Ukraine No. 2939-XII of 26 January 1993. Vidomosti Verkhovnoi Rady Ukrainy. no. 13, 1993. Art. 110. 
Officials of the state financial control body are representatives of executive bodies. Their legal requirements are binding on the officials of the objects under control. Interference in the activities of supervisors entails liability provided by law.

According to Art. 7 of the Law of Ukraine "On Prices and Pricing” ${ }^{1}$, implementation of state pricing policy, economic analysis of the level and price dynamics, development and submission of proposals for the formation and implementation of national pricing policy carried out by the central executive body applying national pricing policy.

In accordance with para. 1 of the Regulation on the State Inspectorate of Ukraine for Price Control, approved by the Decree of the President of Ukraine No. 236/2012 of March 30, $2012^{2}$, the DPI is part of the system of executive authorities and implements national policy on price control. The key missions of this public body are:

- (a) implementation of national price control policy through: constant monitoring, analysis and study of price dynamics (tariffs) in the consumer market and prompt provision of the Cabinet of Ministers of Ukraine, public authorities with assessment and analytical materials on expected changes in the price situation in the country; (b) submitting proposals to central and local executive bodies to determine how to impact economic processes and the price situation in the consumer market; (c) provision, in cases specified by law, with conclusions regarding the economic justification of costs during the formation of prices (tariffs) for goods, works and services in respect of which state regulation of prices (tariffs) has been introduced; (d) public control (supervision) over compliance with the requirements

\footnotetext{
1 Law of Ukraine on Prices and Pricing No. 5007-VI of 21 June 2012. Vidomosti Verkhovnoi Rady Ukrainy, no. 19-20, 2013. Art. 190.

2 Decree of the President of Ukraine on Regulation on the State Inspectorate of Ukraine for Price Control No. 236/2012 of March 30, 2012. Ofitsiinyi visnyk Ukrainy, no. 26, 2012. Art. 969.
} 
One-time gross breach of work duties as the ground for termination of the employment contract at the initiative of the employer

for the formation, establishment and application of state regulated prices; (e) preventing and eliminating pricing breaches;

- making proposals for the formation of a national policy on price control.

In order to optimize the system of central executive bodies and in accordance with para. 9 and 9-1 of Art. 116 of the Constitution of Ukraine, on 10 September 2014, the Cabinet of Ministers of Ukraine decided to liquidate the State Inspectorate for Price Control, entrusting the functions of monitoring the dynamics of prices (tariffs) in the consumer market to the State Statistics Service ${ }^{1}$. Ministries and other central executive bodies were instructed to submit draft government acts on the establishment of commissions to terminate the relevant central executive bodies to the Cabinet of Ministers within a week.

According to Art. 11 of the Law of Ukraine on "State Statistics"2, state statistical bodies include: the central executive body that implements national policy in the field of statistics and functional state statistical bodies enterprises, organisations and institutions subordinate to the central executive body that implements national policy in this field. These bodies form a single system of state statistical bodies of Ukraine.

The State Statistics Service of Ukraine is the specially authorised central executive body, thereof activities are directed and coordinated by the Cabinet of Ministers of Ukraine through the Minister of Economic Development and Trade, which implements national policy in the field of statistics (para. 1 of the Regulation on the State Statistics

1 Resolution of the CMU on the optimization of the system of central executive bodies No. 442 of 10 September 2014. Ofitsiinyi visnyk Ukrainy, no. 74, 2014. Art. 2105.

2 Law of Ukraine on State Statistics No. 2614-XII of 17 September 1992. Vidomosti Verkhovnoi Rady Ukrainy, no. 43, 1992. Art. 608. 
Service of Ukraine, approved by Resolution of the Cabinet of Ministers of Ukraine No. 481 of 23 September $2014^{1}$ ). The key objectives of State Statistics Service of Ukraine are: implementation of national policy in the field of statistics and submission for consideration of the Minister of Economic Development and Trade of proposals regarding the formation of a national policy in the field.

Therefore, there are no laws and logic in the separation by the legislator of revenue and duties officials, nominated for special ranks, as well as officials of central executive bodies implementing national policy in public financial control and price control, as subjects of dismissal for onetime gross breach of work duties.

Moreover, this step of the legislator seems to have no proper and weighty justification. For example, it is unclear why the subjects, covered by paragraph 1 of Art. 31 the LC of Ukraine, involve officials of the State Financial Inspection of Ukraine, while officials of the State Treasury Service of Ukraine or the State Service of Financial Monitoring of Ukraine are not included in this category. Although, it would seem, the objectives performed by these three public institutions are somehow similar, as well as the powers entrusted to them. In addition, the separation of officials of the central executive body, which implements the national policy in the field of price control, does not correspond to the current situation. After all, on September 10, 2014, in order to optimize the system of central executive bodies and in accordance with paragraphs 9 and 9-1 of Art. 116 of the Constitution of Ukraine, the Cabinet of Ministers of Ukraine decided to liquidate the State Inspectorate for Price Control, entrusting the functions of monitoring the dynamics of prices (tariffs) in the consumer market to the State Statistics Service.

1 Resolution of the CMU on approval of Regulation on State Statistics of Ukraine No. 481 of 23 September 2014. Ofitsiinyi visnyk Ukrainy, no. 78, 2014. Art. 2237. 
Under these circumstances and in view of the experience of foreign countries, it seems prudent to extend the scope of para. 1 of Art. 41 of the LC of Ukraine to officials of the sectors of the economy subject to Statutes on discipline (prosecutor's offices, railways, mining companies, etc.).

It should be noted that the Constitutional Court of Ukraine in the case of legal entities' liability ${ }^{1}$ came to the conclusion that in accordance with para. 22 of Part 1 of Art. 92 of the Constitution of Ukraine, only the laws should regulate both the principles of civil, criminal, administrative and disciplinary liability, i.e. acts that are crimes, administrative or disciplinary offenses (the main features of offenses that form their elements), and liability for them. In other words, the elements of any offense, as a basis for bringing a person to legal liability, and actions of public coercion for its commission are determined exclusively by law. In this way, the constitutional justice body forbade regulating these issues by by-laws.

V. O. Holoborodko argues that improvement of the level of protection of employees' rights requires to enshrine in the new Labour Code of Ukraine an exhaustive list of cases whereby labour discipline is regulated exclusively by the Statutes on discipline and proposes to present the relevant article as follows:

"Disciplinary Statutes

1. Disciplinary Statutes regulate labour discipline only of railway transport workers, mining companies, the Prosecutor's Office of Ukraine, the Customs Service of Ukraine, special (militarized) rescue services, civil protection

1 Decision of the Constitutional Court of Ukraine in the case on the constitutional appeal of the All-Ukrainian Joint-Stock Bank on the official interpretation of the provisions of paragraph 22 of part one of Article 92 of the Constitution of Ukraine, parts one, three of Article 2, part one of Article 38 of the Code on Administrative Offenses (case on liability of legal entities) No. 7-rp/2001 of 30 May 2001. Ofitsiinyi visnyk Ukrainy, no. 24, 2001. Art. 1076. 
services, the State Service for Special Communications and Information Protection of Ukraine.

2. Disciplinary Statutes define the duties of managers of enterprises, institutions and organizations to ensure labour discipline, types of incentives and the procedure for their application, types of disciplinary actions and the procedure for their application, the procedure for appealing decisions on the application of disciplinary actions, accounting incentives and disciplinary actions.

3. Disciplinary Statutes are approved by the laws of Ukraine" ${ }^{1}$.

Furthermore, thesubjects oftermination of the employment contract under para. 1 of Art. 41 the LC of Ukraine is the chief accountant of the enterprise, institution, organization and his/her deputy.

The process of identifying, assessing, registering, accumulating, summarizing, storing and transmitting information about the company's activities to external and internal users for decision-making is accounting (Art. 1 of the Law of Ukraine "On Accounting and Financial Reporting in Ukraine” ${ }^{2}$ ). N. Ya. Dondyk argues that it is a system of continuous, total and interconnected observation and documentary reflection of the creation (and monetary expression) of the product and related processes of exchange, distribution, redistribution" ${ }^{3}$. The purpose of such accounting is provision of users for decisionmaking with complete, truthful and unbiased information about the financial position, results of operations and cash

1 Holoborodko, V. O. Legal regulation of internal labour regulations. Ph.D.'s thesis. V. Dahl East Ukrainian National Un-ty. Lugansk, 2012. 190 p.

2 Law of Ukraine on accounting and financial reporting in Ukraine No. 996-XIV of 16 July 1999. Vidomosti Verkhovnoi Rady Ukrainy, no. 40, 1999. Art. 365.

3 Dondyk, N. Ya. The use of special accounting knowledge in the investigation of economic crimes. Ph.D.'s thesis. National University of Internal Affairs. - Kh., 2004. 207 p. 
flows of the enterprise. Accounting is a mandatory type of bookkeeping by an enterprise. Financial, tax, statistical and other types of reporting that use a monetary measure are based on its data.

Accounting is conducted by each enterprise, regardless of its organizational and legal form and form of ownership according to the uniform state rules. This accounting is used in all sectors and subsectors, in industry, agriculture, construction, etc., in all types ofbusiness activities, production, banking, insurance. In each of these fields of activity, in each branch of management it has specific features. For example, at the machine-building plant the subject of accounting is the whole process of manufacture and sale of machinery and equipment, in the construction organization, that is, the process of creation and sale of construction products (finished objects, construction and installation work). However, the initial provisions of accounting are the same, common to all activities and in all sectors of the economy.

At present, special accounting knowledge means not only knowledge of the principles of organization and maintenance of accounting, accounting records, understanding of the economic content of the balance sheet, but also the knowledge necessary for a qualified assessment of the financial condition of the enterprise, prospects for its development and adoption of sound financial, economic and management decisions.

The bearer of special accounting knowledge and the subject of their application is the relevant specialist, that is a person who has received professional training and has the skills to apply such knowledge.

Accounting at the enterprise is conducted continuously from the date of registration of the latter until its liquidation. To ensure accounting, the company independently chooses the forms of its organization: a) the introduction of the position of an accountant in the company's staff or the creation of an 
accounting department headed by the chief accountant; b) the use of the services of an accounting specialist registered as an entrepreneur who carries out business activities without creating a legal entity; c) maintenance on a contractual basis of accounting by a centralized accounting firm or audit firm; d) independent accounting and reporting directly by the owner or manager of the enterprise.

In general, we advocate the categorical statement of A. Aivazova, "Probably, no one will dispute the statement that the position of an accountant at the enterprise is the most responsible. And there is no need to explain why" ${ }^{1}$. According to Art. 8 of the Law "On Accounting and Financial Reporting in Ukraine," a chief accountant or a person entrusted with the accounting of the enterprise:

- ensures compliance with the established uniform methodological principles of accounting, preparation and submission of financial statements in a timely manner;

- organizes control over the reflection on the accounts of all business transactions;

- participates in the preparation of materials related to the shortage and reimbursement of losses from shortages, theft and damage to the assets of the enterprise;

- provides verification of the state of accounting in branches, representative offices, offices and other separate divisions of the enterprise;

- submits in the prescribed manner and in cases provided by the Law of Ukraine "On prevention and counteraction to legalization (laundering) of proceeds from crime, financing of terrorism and financing of proliferation of weapons of mass destruction" ${ }^{2}$, information to the central executive

1 Aivazova, A. Limits of accountant's responsibility: What you need to know. Advokat bukhgaltera, no. 21 (123), 2006: 19.

2 Law of Ukraine on prevention and counteraction to legalization (laundering) of proceeds from crime, financing of terrorism and financing of proliferation of weapons of mass destruction No. 1702-VII of 14 October 2014. Vidomosti Verkhovnoi Rady Ukrainy, no. 50-51, 2014. Art. 2057. 
One-time gross breach of work duties as the ground for termination of the employment contract at the initiative of the employer

body implementing national policy in the field of prevention and counteraction to legalization (laundering) of proceeds from crime, terrorist financing and the financing of the proliferation of weapons of mass destruction.

Missions and functional duties of the accounting service of a budgetary institution, the powers of its head, the chief accountant, and the requirements for his/her professional qualification levelare determined by the Standard Regulations on the accounting service of a budgetary institution, approved by Resolution of the Cabinet of Ministers of Ukraine No. 592 of 26 January $2011^{1}$.

The Qualification characteristics of occupations of workers, approved by Order of the Ministry of Labour and Social Policy of Ukraine No. 336 of 29 December $2004^{2}$ provides for missions and duties of chief accountants, establishes qualification requirements for them and provides that these qualification characteristics are used as regulations in the development of job descriptions for employees of all positions specified in the staff list of the enterprise and approved by the head of the latter. According to these qualification characteristics, the chief accountant manages the accounting staff of the enterprise, distributes among them job missions and duties, acquaints them with regulatory and methodological documents and information materials related to their activities, as well as with changes in current legislation. Therefore, the position of a chief accountant presupposes the presence of subordinate employees.

1 Resolution of the CMU on Standard Regulations on the accounting service of a budgetary institution No. 59 of 26 January 2011. Ofitsiinyi visnyk Ukrainy, no. 8, 2011. Art. 372.

2 Order of the Ministry of Labour and Social Policy of Ukraine on approval of Issue 1 "Occupations of workers that are common to all types of economic activity" of Chapter 3 “Occupations of managers, professionals, specialists and technical employees that are common to all types of economic activities” of Qualification characteristics of occupations of workers No. 336 of 29 December 2004. Ukr. Invest. Gas, 45, 2007. Art. 164. 
At the same time, according to the National Classifier of Ukraine DK 003:2010 “Classifier of Occupations", approved by Order of State Committee of Ukraine for Technical Regulation and Consumer No. 327 of 28 July $2010^{1}$, the occupational title of the job "Chief Accountant" under the Classifier code (code 1231) belongs to the occupational group "Heads of financial, accounting, economic, legal and administrative divisions and other heads". Therefore, the introduction of the position of a chief accountant in the staff list of the enterprise is possible in case of creating an appropriate structural division. Based on the fact that most enterprises in Ukraine are small, to ensure accounting, they are often limited to the introduction in the staff only an accountant, rather than the creation of an accounting department headed by the chief accountant. Therefore, according to Art. 8 of the Law "On accounting and financial reporting in Ukraine”, para. 1 of Art. 41 of the LC of Ukraine should cover not only the chief accountants of enterprises, institutions, organizations, their deputies, but also the persons responsible for accounting of the business entity.

Indirectly current legislation provisions confirm this position, establishing legal liability for wrongdoing by both chief accountants and persons responsible for accounting of the business entity. For example, according to Art. 164-2 of the $\mathrm{CAO}$, concealment in accounting of foreign exchange and other income, unproductive expenses and losses, lack of accounting or keeping it with breach of the established order, entering false data in financial statements, failure to submit financial statements, untimely or poor inventory of cash, pecuniary assets, untimely submission for consideration, consent or approval of the annual financial plan of the public sector of the economy and the report on its implementation,

\footnotetext{
1 Classifier of Occupations DK 003: 2010 (approved by Order of the State Committee of Ukraine on tech. regulation and consumption policy No. 327 of 28 July 2010. http://kadry.at.ua/blog/ klasifikator_profesij_dk_003_2010/2010-11-08-16.
} 
obstruction the exercise of audits and inspections by employees of the state financial control body, failure to compensate for losses, waste, theft and mismanagement by guilty persons - shall entail the imposition of a fine in the amount of from eight to fifteen times the minimum wage. The same actions committed by a person subject to an administrative penalty for one of the offenses referred to in part one of this article during the year - shall entail the imposition of a fine in the amount of ten to twenty times non-taxable minimum wage. According to Part 3 of Art. 166-6 of the CAO, lack of accounting or its maintenance with breach of the established procedure, untimely, incomplete or with breach of the established procedure of carrying out inventory of property, breach of the procedure of carrying out property assessment, drawing up liquidation balance (intermediate balance), distributive balance, transfer deed at termination of legal persons - shall entail the imposition of a fine on officials of the legal entity, other persons involved in the termination of the legal entity, in the amount of from 100 to 150 times non-taxable minimum wage.

Another and, obviously, the most important entity that can be dismissed for committing one-time gross breach of work duties, is the head of the enterprise, institution, organization of all forms of ownership (suboffice, representative office, branch and other separate division) and his/her deputies.

The successful operation of the enterprise in general, as well as the successful performance of each member of its workforce, requires significant efforts to organize them, to determine the target, coordination of their actions, i.e. requires management. Therefore, management is to some extent an independent activity that involves the ability to influence individual employees and the team in general so that they work towards achieving the goals and objectives 
of a particular division or the whole entity for its effective functioning.

In the history of society, discussions about determination of the essence and nature of leadership have been arising. It should be considered that the majority of people are subconsciously convinced that they know how to manage most effectively (even without theoretical knowledge or practical experience), unlike any other activity ${ }^{1}$.

The comprehensive social structure has enabled O. M. Okhotnikova to consider the importance of the leader in several gradations of the social dimension at the levels defined by this study, namely the environment:

- macro-social, which involves a set of socio-legal relations between the subjects and objects of the external environment;

- micro-social, which should be considered as a set of socio-legal relations between the subjects of the internal environment;

- meso-social, which should be considered as a set of socio-legal relations between the subjects of the external and internal organizational environment;

- interpersonal environment is a set of socio-legal relations between the subject and the objects of management at the level of personal relations of activity ${ }^{2}$.

The scale of the social dimension of the leader's role is differentiated according to the social structure, and mobile, as a mobile social environment whereby the activities of organizations and their employees implement.

Under modern conditions, the key requirement for the head is the ability to overcome challenges emerging in economic practice, contradictions between state and

\footnotetext{
1 Ortynskyi, V. L., Kisil, Z. R. Kovaliv, M. V. Management in the executive authorities of Ukraine. K.: Tsentr. uchb. lit., 2008. 296 p.

2 Okhotnikova, O. M. Administrative liability of the head of a public enterprise, institution, organization in Ukraine. Ph.D.'s thesis. Nat. Acad. State Tax. Services of Ukraine. Irpen, 2004. 203 p.
} 
collective interests and the ability to reconcile them, adhering to the priority of common human interests in economic issues, where the key form of such activities is a managerial decision, its preparation, adoption and implementation, for which the head should be responsible. The effectiveness of his/her performance is assessed by the indicators as follows: (a) his/her work team productivity, (b) the success of occupational tasks, (c) the psychological climate in the team, (d) employee health and the absence of injury, (e) turnover of personnel, etc.

According to Art. 65 of the Economic Code of Ukraine, management of the enterprise is carried out in compliance with its constituent documents on the basis of a combination of the rights of the owner as to the economic disposal of his/her property and participation of the staff in the management. The owner exercises his/her rights as to enterprise management directly or through authorized bodies in accordance with the enterprise charter or other constituent documents. This authorized body or person can be the directorate, the board, the director, the chairman of the board, or another governing body. In this regard the arguments of B. B. Cherepakhin are worth mentioning. According to him, the concepts of "a body of the legal entity" and "a body of its administration" are by no means identical. The second covers all officials of the body who manage the enterprise as a whole and its individual divisions. The administration consists of the director, his/her deputies and assistants, the chief engineer, heads of workshops, services, productions, farms, etc. These are persons who perform management functions at the enterprise and in its divisions. The governing body of a legal entity, along with the acts of internal management of the enterprise also performs external acts of management of enterprises, institutions, organizations as a legal entity, aimed at establishing, changing and terminating civil 
rights and obligations, as well as their implementation and protection $^{1}$.

To manage the economic activity of the enterprise, the owner or his/her authorized body appoints a manager. According to the State Classifier of Occupations, the managers can be considered: general director; head, president, other leaders of associations; president of an association, corporation, concern; director of any educational institution, secondary school; director of the plant; chief physician of the treatment and prevention institution, etc.

The current legislation of Ukraine provides for a number of restrictions on the appointment of certain categories of persons to the position of the head of the enterprise. In particular, such restrictions apply to: people's deputies of Ukraine; members of the Cabinet of Ministers of Ukraine; heads of central and other executive bodies; servicemen; notaries; deputies of local councils who work fulltime in these councils; officials of the prosecutor's office, court, state security, internal affairs, public authorities and local governments, except when they perform the functions of management of shares (portions, divvies) owned by the state and represent the interests of the state in the supervisory board or audit company commissions; persons who have been prohibited by the court from engaging in certain activities (if the enterprise carries out this type of activity); persons who have an outstanding criminal record for theft, bribery and other mercenary crimes (Art. 23 of the Law of Ukraine "On Business Associations" ${ }^{2}$ ); chairmen of the general meeting of participants and members of the audit commission of a limited liability company, who cannot be members of its executive body at the same time (Art. 62 and 63 of the Law of Ukraine “On Business Associations”);

1 Cherepakhin, B. B. Proceedings on Civil Law. M.: Statut, 2001. 479 p.

2 Law of Ukraine on business associations No. 1576-XII of 19 September 1991. Vidomosti Verkhovnoi Rady Ukrainy, no. 49, 1991. Art. 682. 
members of the supervisory board and the audit commission of the joint-stock company, who cannot be members of its executive body at the same time (Art. 53 and 58 of the Law of Ukraine “On Joint-Stock Companies" ${ }^{1}$ ), etc.

In case of hiring the head of the enterprise, an agreement (contract) is concluded with him/her, which determines the term of employment, rights, duties and responsibilities of the head, conditions of his/her renumeration, conditions of dismissal and other conditions of employment upon the approval of the parties. The provisions are detailed in Resolution of the Cabinet of Ministers of Ukraine "On streamlining the contractual form of employment agreement” No. 170 of 19 March $1994^{2}$. It should be considered that the procedure for concluding, and terminating employment agreements (contracts) with the heads of state-owned enterprises is regulated by other regulations, in particular, government Resolution "On the application of the contractual form of employment agreement with the head of the state-owned enterprise" No. 203 of 19 March $2005^{3}$. The key feature of the contract with the head of the state-owned enterprise is the requirement to agree on its conclusion and termination with the relevant ministry or other executive body.

In general, the issue of appointment, activity and dismissal of the head is complex by its nature. It is due to a dual status of such a position, i.e. a combination of aspects, corporate labour and labour law. According to O. Pavlynska argues, on the one hand, the head, as an employee, is in an employment

Law of Ukraine on Joint-Stock Companies No.514-VI of 17 September 2008 p. Vidomosti Verkhovnoi Rady Ukrainy, no. 50-51, 2008. Art. 384.

2 Resolution of the CMU on streamlining the contractual form of employment agreement No. 170 of 19 March 1994. Ukr. Invest. Gas., 10, 2003. Art. 174.

3 Resolution of the CMU on the application of the contractual form of employment agreement with the head of the state-owned enterprise No. 203 of 19 March 2005. Ukr. Invest. Gas., 50, 2007. Art. 203. 
relationship with the enterprise, on the other, he/she is appointed by the owner by decision at a general meeting of shareholders or at a meeting of the supervisory board (for joint stock companies), at general meeting of participants (for limited liability companies) or by issuing a decision of the sole owner (for such outdated organizational and legal forms as a private enterprise, etc.). The procedure for the appointment of the head and the procedure for his/ her removal from office are regulated by corporate law. However, the employment relationship with the employee requires to be duly completed in view of labour law provisions. In addition, according to labour law, the head is the body authorized by the owner, and therefore in practice he/she represents the latter in relations with the personnel, while entering it as an employee. Obviously, in practice this "duality" of the position raises many questions, especially regarding the design of the relationship in the case where the owner and manager are one and the same ${ }^{1}$.

The head of the enterprise acts on behalf of the enterprise without a power of attorney, represents its interests in public authorities and local governments, other organizations, in relations with legal entities and citizens, forms the administration of the enterprise and decides on the latter within the limits and procedure specified by the constituent documents. According to T. A. Zanfirova, the management of the labour process requires effective levers of management to ensure the implementation of managerial decisions, while effective feedback is necessary for the proper functioning of the collective work. Therefore, the employer is endowed with a certain power regarding employees: a) regulatory, that is, the right to establish provisions, binding on employees in their duty status of joint work; b) directive, that is, to give employees mandatory instructions, including on issues not

\footnotetext{
1 Pavlynska, O. Appointment of the founder as the head. Labour and law, no. 10(166), 2013: 17.
} 
regulated by legal means; c) disciplinary, that is, to apply the liability actions provided by law to breaches of legal provisions, and employer's instructions issued according to these statutory provisions ${ }^{1}$.

An important aspect of the executive body's activity is the existence of mechanisms of responsibility of the director and members of the collegial body. The manager's responsibility is one of the signs of the interdependence of the individual and society. After all, the larger the field of macro-social activity of the leader, the more complex the intertwining of its determinants, the higher the conditions for a correct understanding of the goal and the choice of means to achieve it, i.e. the greater the responsibility of the leader. The head's freedom is inseparable from his/her responsibility, because it is connected with his/her personal values, it is impossible without understanding the purpose, without consistency, which ensures the unity of theory and practice. Freedom to perform managerial activity is the head's ability to act competently to achieve his/her chosen goal, which is realized more fully, the better the knowledge of objective conditions, the more the chosen goal and means to achieve it correspond to objective conditions and natural trends. According to Art. 92 of the CC of Ukraine ${ }^{2}$, if members of a legal entity's body and other persons, who in accordance with the constituent documents or the law act on behalf of the legal entity, violate their obligations regarding representation, they shall bear joint responsibility for the losses inflicted thereby to the legal entity. In particular, according to this provision, the body or the person, which in accordance with the legal entity's constituent documents

1 Zanfirova, T. A. Legal regulation of labor relations with the participation of the employer - an individual. Ph.D.'s thesis. Yaroslav Mudryi National Law University. Kh., 2004. 224 p.

2 Civil Code of Ukraine (approved by Law of Ukraine No. 435-IV of 16 January 2003). Vidomosti Verkhovnoi Rady Ukrainy, no. 40-44, 2003. Art. 356. 
or the law acts on its behalf, is obliged to perform fair and reasonable actions in the interests of the legal entity and not to exceed its/his/her powers. Additional disciplinary liability of managers is established in the case of one-time gross breach of work duties.

Moreover, the head not only of the enterprise, but also of its separate division is subject to para. 1 of Art. 41 the LC of Ukraine. The enterprise, while creating a suboffice, representative office, branch, other separate division, agree on their placement with the relevant local governments in the manner prescribed by law. In addition, enterprises have the right to create structural divisions -workshops, sections, teams, offices, laboratories, etc., as well as functional structural divisions of management - departments, offices, departments, offices, services, etc.

According to article 1 of the Law of Ukraine "On state registration of legal entities and individual entrepreneurs" ${ }^{1}$, a separate division is a suboffice, another division of a legal entity located elsewhere, manufactures products, performs works or operations, provides services on its behalf, or a representative office, representing and protecting the interests of a legal entity. Such separate divisions are not subject to state registration. Article 95 of the Civil Code of Ukraine defines a suboffice as a separate division of a legal entity situated outside its location, which performs all or part of its functions, and a representative office is a separate division of a legal entity situated outside its location that represents and protects the legal entity's interests. Neither the suboffice nor the representative office are independent legal entities, but are provided the property of the legal entity, which has created them, and act on the basis of the regulations approved thereby.

1 Law of Ukraine on state registration of legal entities and individual entrepreneurs No. 755-IV of 15 May 2003. Vidomosti Verkhovnoi Rady Ukrainy, 31-32, 2003. Art. 263. 
Therefore, the issue of whether the head of the structural division of a legal entity belongs to the persons with whom the employment contract can be terminated due to onetime gross breach of work duties, requires considering both property and territorial separation of the division headed by this person, as well as the fact that according to Art. 64 of the Economic Code of Ukraine, the enterprise has the right to create suboffice, representative office, branch, other separate division, coordinating issues as to their location with relevant local governments. Provisions of the Civil Code of Ukraine do not prevent legal entities from creating separate divisions not only in other settlements, but also in the same settlement where the legal entity is located. It is only important that this division is property-separated. Such division does not have the legal entity status, and act on the basis of a relevant provision, approved by an enterprise. Accordingly, the persons who head such divisions and perform organizational and administrative functions have the status of the head of a separate division.

It should be noted that, for example, the chief accountant is not only persons who hold the position with the appropriate title, but also those who perform the relevant duties at the time of one-time gross breach and dismissal.

Therefore, para. 1 of Part 1 of Art. 41 the LC of Ukraine should be amended as follows:

"one-time gross breach of employment duties by the head of a legal entity or a separate structural division, his/ her deputies, the chief accountant, his/her deputies, officials responsible for accounting, as well as officials covered by the Statutes on discipline.”

The results of a comprehensive study in the third subsection of the monograph enable to make conclusions of significant theoretical and applied significance.

1. Therefore, there are no laws and logic in the separation by the legislator of revenue and duties officials, nominated 
for special ranks, as well as officials of central executive bodies implementing national policy in public financial control and price control, as subjects of dismissal for onetime gross breach of work duties. Moreover, this step of the legislator seems to have no proper and weighty justification. For example, it is unclear why the subjects, covered by paragraph 1 of Art. 31 the LC of Ukraine, involve officials of the State Financial Inspection of Ukraine, while officials of the State Treasury Service of Ukraine or the State Service of Financial Monitoring of Ukraine are not included in this category. Although, it would seem, the objectives performed by these three public institutions are somehow similar, as well as the powers entrusted to them. In addition, the separation of officials of the central executive body, which implements the national policy in the field of price control, does not correspond to the current situation: after all, on September 10, 2014, in order to optimize the system of central executive bodies and in accordance with paragraphs 9 and 9-1 of Art. 116 of the Constitution of Ukraine, the Cabinet of Ministers of Ukraine decided to liquidate the State Inspectorate for Price Control, entrusting the functions of monitoring the dynamics of prices (tariffs) in the consumer market to the State Statistics Service. Under these circumstances and in view of the experience of foreign countries, it seems prudent to extend the scope of para. 1 of Art. 41 of the LC of Ukraine to officials of the sectors of the economy subject to Statutes on discipline (prosecutor's offices, railways, mining companies, etc.).

It should be noted that the Constitutional Court of Ukraine in the case of legal entities' liability came to the conclusion that in accordance with para. 22 of Part 1 of Art. 92 of the Constitution of Ukraine, only the laws should regulate both the principles of civil, criminal, administrative and disciplinary liability, i.e. acts that are crimes, administrative or disciplinary offenses (that have 
main features of offenses, which form their elements), and liability for these offenses.

2. To ensure accounting, the enterprise independently chooses the forms of its organization, including the introduction of the position of an accountant in the company's staff or the creation of an accounting department headed by the chief accountant. According to the Qualification characteristics of occupations of workers, approved by Order of the Ministry of Labour and Social Policy of Ukraine No. 336 of 29 December 2004, a chief accountant manages the accounting staff of the enterprise, distributes among them job missions and duties, acquaints them with regulatory and methodological documents and information materials related to their activities, as well as with changes in current legislation. At the same time, according to the Classifier of Occupations DK 003:2010, approved by Order of State Committee of Ukraine for Technical Regulation and Consumer No. 327 of 28 July 2010, the occupational title of the position "Chief Accountant” under the Classifier code (code 1231) belongs to the occupational group "Heads of financial, accounting, economic, legal and administrative divisions and other heads". Therefore, the introduction of the position of a chief accountant in the staff list of the enterprise is possible in case of creating an appropriate structural division. Based on the fact that most enterprises in Ukraine are small, that to ensure accounting, they are often limited to the introduction in the staff only a position of an accountant, rather than the creation of an accounting department headed by the chief accountant, therefore, according to Art. 8 of the Law "On accounting and financial reporting in Ukraine”, para. 1 of Art. 41 of the LC of Ukraine should cover not only the chief accountants of enterprises, institutions, organizations, their deputies, but also the persons responsible for accounting of the business entity. 
3. The successful operation of the enterprise in general, as well as the successful performance of each member of its workforce, requires significant efforts to organize them, to determine the target, coordination of their actions, i.e. requires relevant management. The management is to some extent an independent activity that involves the ability to influence individual employees and the team in general so that they work towards achieving the goals and objectives of a particular division or the whole entity for its effective functioning.

Under modern conditions, the key requirement for the head is the ability to overcome challenges emerging in economic practice, contradictions between state and collective interests and the ability to reconcile them, adhering to the priority of common human interests in economic issues, where the key form of such activities is a managerial decision, its preparation, adoption and implementation, for which the head should be responsible. The effectiveness of his/her performance is assessed by the indicators as follows: (a) his/her work team productivity, (b) the success of occupational tasks, (c) the proper psychological climate in the team, (d) employee health in the absence of injury, (e) turnover of personnel, etc.

The issue of whether the head of the structural division of a legal entity belongs to employees with whom the employment contract can be terminated due to one-time gross breach of work duties, requires considering both property and territorial separation of the division headed by him/her, as well as the fact that according to Art. 64 of the Economic Code of Ukraine, the enterprise has the right to create suboffice, representative office, branch, other separate division, coordinating issues as to their location with relevant local governments.

Provisions of the Civil Code of Ukraine do not prevent legal entities from creating separate divisions not only in 
other settlements, but also in the same settlement where the legal entity is located. It is only important that this division is property-separated. Such divisions do not have the legal entity status, and act on the basis of a relevant provision, approved by an enterprise. The person who heads such division and performs organizational and administrative functions have the status of "the head of a separate division.

4. The possibility of terminating the employment contract at the initiative of the employer with the head of the legal entity or a separate structural division, his/her deputies, the chief accountant, his/her deputies, officials responsible for accounting, as well as with officials, covered by Statutes on discipline requires legislative consolidation. An approximate version of this provision is formulated.

\subsection{The Procedure for Termination of the Employment Contract in case of One-Time Gross Breach of Work Duties}

Implementation of social regulation requires certain procedures and relevant provisions. Mandatory procedurality feature is characteristic of the legal regulation system, as it not only ensures the formation of legal requirements, but also determines the formation of their implementation mechanism in society. A well-defined procedural and legal mechanism is an important guarantee against abuse of power. Procedural form is essential not only for the establishment of standards for possible or required conduct, but also for the procedure for performing legally binding acts. Procedurality and standardisation are most fully expressed in legal regulation. In this regard, the procedural and legal mechanism is an integral part, the most important internal mechanism of the legal regulation system. 
One-time gross breach of work duties as the ground for termination of the employment contract at the initiative of the employer

V. E. Kuznechenkova argues that the legal procedure is a special procedure of legal activity, established by provisions of law, and guarantees compliance of the latter with legal requirements, as well as focuses the legal person on achieving the legal purpose ${ }^{1}$. According to I. M. Zaitsev, the role of legal procedure in the modern state is growing significantly, as the legal regime in it should be determined primarily by the technology of implementation of legal provisions. The most important thing is not to decide what to do, but how to act ${ }^{2}$.

K. V. Nikolina reveals the essential features of the legal procedure, namely:

- it is a special type of legal relationship that has a procedural nature and determines the features of legal practice;

- it is holistic, as it consists of certain successive actions of its subjects, as a result of which the corresponding effect is achieved;

- it arises on the basis of provisions of law, i.e. has an official legal nature;

- the legal procedure is implemented in the manner governed by the relevant procedural provisions of law;

- it has its own focus, which is to change the legal reality;

- it is intellectual and volitional, as it depends on the consciousness and will of its subject;

- it determines the sequence in the activities of its subjects;

- the result of the legal procedure is the realization of the rights, freedoms and legitimate interests of a legal person or the performance of legal duties;

- it is manifested in legal activities;

1 Kuznechenkova, V. E. Tax law-making process in the system of legal categories. Zhurn. Ros. Prava, 1. 2005: 34-37.

2 Matuzova, N. I., Malko, A. V. (Eds.). Theory of state and law. 2nd ed. Moscow: Yurist, 2001. 776 p. 
- it is a set of successive acts of conduct, each of them causes the corresponding local results, which affect the content and effectiveness of the entire legal procedure ${ }^{1}$. Therefore, the legal procedure is a special legal phenomenon, an appropriate system aimed at achieving a specific legal effect.

Furthermore, termination of the employment contract at the initiative of the employer in case of one-time gross breach of work duties has its procedure.

Disciplinary proceedings should be recognized as the key component of the latter. In para. 22 of Resolution "On the practice of consideration of labour disputes by courts” No. 9 of 6 November 1992, Plenum of the Supreme Court of Ukraine indicates that in cases of reinstatement of persons dismissed for breach of labour discipline, courts is required to find out what exactly the breach that has led to the dismissal is, whether it could be grounds for termination of the employment contract under para. 1 of Art. 41 of the LC of Ukraine, whether the owner or his/her authorized body complies with the rules and procedures provided for in Articles 147-1, 148 and 149 of this Code for the application of disciplinary actions, in particular, whether the time limit set for this has expired, whether disciplinary action has already been taken during this misdemeanour, whether the gravity of the misdemeanour and the damage caused by it have been taken into account during dismissal, as well as the circumstances under which it was committed, and the employee's previous work. In practice, however, infrequently both employers and courts ignore this guideline.

Now a specific case will be considered. On June 15, 2006, O. filed a lawsuit against the Culture Department of the Executive Committee of the Cherkasy City Council for her

1 Nikolina, K. V. Legal procedure: Concepts, features, types, place in the system of legal categories. Ph.D.'s thesis. Kyiv. University of Law. K., 2011. $215 \mathrm{p}$. 
reinstatement and recovery of average earnings during the forced truancy. By a decision of the Sosnivskyi District Court of Cherkasy of 5 February 2007, upheld by a decision of the Cherkasy Regional Court of Appeal of 6 April 2007, O.’s suit was dismissed.

However, the panel of judges of the Judicial Chamber for Civil Cases of the Supreme Court of Ukraine takes the position that O.'s cassation appeal is subject to partial satisfaction. The courts found that O. worked as a deputy director for educational work at Cherkasy Children's Music School No. 1, and Order of the Department of Culture of the Executive Committee of the Cherkasy City Council No. 9-k of 5 June 2006 dismissed the plaintiff from office according to para. 1 of Art. 41 of the LC of Ukraine and transferred to the position of a teacher of music theory. The grounds for dismissal were the letter of the State Audit Service of Ukraine in Cherkasy region No. 23-03/31-1586 of 31 March 2006, and a letter from the director of Cherkasy Children's Music School No. 1 of 29 May 2006, no. 70/3. By Order of the Culture Department of the Executive Committee of the Cherkasy City Council No. 12-k of 26 June 2006, Order No. 9-k was amended. The plaintiff was dismissed from the position of Deputy Director on the grounds of one-time gross breach of labour discipline (inaccuracy of data in the primary accounting documents that led to unlawful labour costs of teacher P. (SASU act No. 01-45/017 of 6 March 2006, letter of the SASU of Ukraine No. 23-03/31 of 31 March 2006). In proceeding, the courts considered the fact that according to the audit certificate of the control and audit department in Cherkasy of 6 March 2006, No. 01-45/017, plaintiff O., whose duties included drawing up a payroll for teachers, committed one-time gross breach of labour discipline, that is, showed negligence, did not check the accuracy of the data, which led to unlawful labour costs of teacher P. for October 2004. Moreover, the courts did not establish at 
all when the plaintiff committed actions that were onetime gross breach of labour discipline, and whether the defendant complied with the 6-month period provided for in Part 2 of Art. 148 of the LC of Ukraine, when imposed on $\mathrm{O}$. a disciplinary action in the form of dismissal ${ }^{1}$.

Termination of the employment contract in case of one-time gross breach of work duties should be clearly distinguished from termination of the employment contract with the head at the request of the elected body of the primary trade union organization (trade union representative).

According to part 1 of Art. 45 of the LC of Ukraine, at the request of the elected body of the primary trade union organization (trade union representative) the owner or his/ her authorized body is required to terminate the employment contract with the head of the enterprise, institution or organization, if he/she breaches laws on labour, collective agreements and contracts, Law of Ukraine "On trade unions, their rights and guarantees of activity" ${ }^{2}$. It should be noted that such dismissal requirements apply only to heads and should not apply to his/her deputies, heads of structural divisions and their deputies.

O. A. Yakovliev argues, "This is due to the fact that in modern conditions, all these people are employees. They are hired and dismissed by the head of the enterprise, institution, organization. Although deputy heads, chief specialists, and heads of structural divisions are included in the management structure, they differ little in their legal status from other employees” ${ }^{3}$.

\footnotetext{
1 On reinstatement and recovery of average earnings during forced truancy (case no. 6-12596sv07). http://reyestr.court.gov.ua/.

2 Law of Ukraine on trade unions, their rights and guarantees of activity No. 1045-XIV of 15 September 1999. Vidomosti Verkhovnoi Rady Ukrainy, no. 45, 1999. Art. 397.

3 Yakovlev, O. A. Termination of the employment contract on the initiative of third parties who are not parties to the employment contract. Ph.D.'s thesis. Yaroslav Mudryi National Law University. Kh., 2003. 189 p.
} 
In this case, the head of a legal entity breaches laws on labour, collective agreements and contracts. These breaches concern the rights and guarantees of all or most employees in the enterprise, institution or organization, destroying the normal social relations between the head and employees. The dismissal of one person - the head - provides for the rights and guarantees of all employees.

According to O. H. Sereda, dismissal of the head of an enterprise, institution or organization at the request of trade unions should not be considered a disciplinary action ${ }^{1}$. It is worth agreeing with the position of the scientist. According to this article, dismissal is not a disciplinary action and is not related to compliance with the deadlines and procedures provided for in Art. 148 and 149 of the LC of Ukraine. In other words, a trade union that requires termination of the employment contract with a head is not required to keep within one-month term from the discovery of a misdemeanour by the manager and six-month term from the date of the offense. Moreover, this conclusion is the only correct because the head of the enterprise, institution or organization is not subordinated to trade unions, and trade unions are not endowed with the right to apply disciplinary actions to the head and other employees.

According to Part 1 of Art. 45 of the LC of Ukraine, the request of the elected body of the primary trade union organization (trade union representative) is mandatory not only for consideration but also for execution. If the employer or his/her authorized body or the head, in respect of whom termination of the employment contract is requested, does not agree, he can appeal the decision of the trade union body to the court within two weeks from the date of receipt of the decision. In this case, the fulfilment of the request for termination of the employment contract is

1 Sereda, O. Duties of employer legal effects of their ignorance. Law of Ukraine, no. 9, 2002: 83-84. 
suspended until the court makes a decision. If the decision of the trade union body is not executed and is not appealed within the specified period, the trade union body can within the same period appeal to the court against the actions or inactivity of officials or bodies responsible for terminating the employment contract with the head of the enterprise, institution or organization.

Therefore, the main differences between termination of the employment contract in the cases provided for in para. 1 of Part 1 of Art. 41 of the LC and Art. 45 of the LC are as follows:

a) the former occurs at the initiative of the employer, while the initiator of the latter is the elected body of the primary trade union organization (trade union representative);

b) the first is the ground for dismissal of the head of the enterprise or a separate division, his/her deputies, the chief accountant of the enterprise, his/her deputies, as well as officials of the revenue and duties bodies nominated for special ranks, and officials of central executive bodies implementing national policy in public financial control and price control, and the second - only of the head of the legal entity;

c) the grounds for termination of the employment contract in the first case are one-time gross breach of work duties, in the second - breach of laws on labour, collective agreements and contracts, the Law of Ukraine "On trade unions, their rights and guarantees of activity”. In the second case, breaches concern labour rights and guarantees of their provision for all or most employees of the enterprise;

d) dismissal on the first ground is a disciplinary action, and on the second, it is not such an action;

e) in the first situation, dismissal is the right of the employer, who may not use it, in the second, the latter is obliged to terminate the employment contract. As mentioned above, dismissal in case of employee's one-time gross breach 
of work duties is a type of disciplinary action that can be imposed on that person by the employer. According to Art. 147-1 of the LC Ukraine, disciplinary actions are applied by the body empowered with the right to employ persons (elect, approve and appoint). Moreover, the next higher authority can impose disciplinary actions on employees, subject to disciplinary liability under the Statutes, regulations and other acts of disciplinary legislation. Employees holding elected positions can be dismissed only by a decision of the body that elected them, and only on the grounds provided by law. The importance of taking into account these legal requirements is illustrated by an example from case law.

On May 2010, V. filed a lawsuit against the Housing and Communal Services Department 'Alternatyva' of the Volodymyr Village Council of the Zaporizhzhia District of the Zaporizhzhia Region to reinstate, recover the average wage during the forced truancy, and non-pecuniary damage. The decision of the Zaporizhzhia District Court of the Zaporizhzhia Region of 3 February 2011, upheld by the decision of the Court of Appeal of the Zaporizhzhia Region of 4 May 2011, dismissed the claim.

The panel of judges of the High Specialized Court of Ukraine for Civil and Criminal Cases concluded that V.'s cassation appeal was subject to partial satisfaction. It was established that since 15 March 2007 the parties had been in an employment relationship and the plaintiff worked as the director of HCSD 'Alternatyva' in accordance with the decision of Volodymyr Village Council No. 61 of 15 March 2007. According to Ordinance No. 8 of 23 April 2010 of the Volodymyr Village Council, V. was dismissed from his post in connection with the breach of financial discipline in the performance of his work duties. According to Art. 42 of the Law "On local self-government in Ukraine" ${ }^{1}$, in case

1 Law of Ukraine on local self-government in Ukraine No. 280/97-BP of 21 May 1997. Vidomosti Verkhovnoi Rady Ukrainy, 24, 1997. Art. 170. 
of dismissal of the village, settlement chief, city mayor, his/ her authorities are exercised by the secretary of the relevant council. Ordinance on dismissal of the plaintiff is signed by acting village chief $\mathrm{H}$. Elements of the claim of $\mathrm{V}$. on his dismissal by an unauthorized person were duly checked by neither the court of first instance nor the appellate court, nor was it clarified why the issue had not been resolved by the secretary, what authorities were delegated to the acting village head $G$. in the absence of the head of the Volodymyr Village Council. Regarding breach of the above requirements of the law, the courts did not properly verify compliance with the procedure for imposing a disciplinary action on the plaintiff under Art. 149 of the LC of Ukraine, as well as the gravity of his guilt and his elements of the claim regarding the unlawfulness of the dismissal, and did not provide facts that would refute such elements ${ }^{1}$.

V. S. Kovryhin argues that in order to improve the law application practice, a provision, according to which the employer has the right to transfer the authority regarding disciplinary actions to one of his/her deputies or the head of a separate structural division of the legal entity, requires to be legislated. According to the scientist, such an order should state the reason for the transfer of this right to another official, clearly define the scope of its authorities and the term of their transfer ${ }^{2}$.

The law application authority can find breach of work duties gross, based on the nature of a misdemeanour, circumstances whereby it was committed, the damage caused or could have been caused by the employee. This is onetime, not ongoing breach of work duties, which may entail the application of disciplinary actions on other grounds. In

1 On reinstatement and recovery of average earnings during forced truancy (case no. 6-22208sv11). http://reyestr.court.gov.ua/.

2 Kovryhin, V. S. Disciplinary liability in Labor Law. Ph.D.'s thesis. T. Shevchenko Kyiv National University. K., 2012. 221 p. 
other words, if breach is long-term (for example, weakening or lack of control over the work of subordinates), and is not one-time, the dismissal under para. 1 of Art. 41 of the LC of Ukraine is impossible.

According to Art. 148 of the LC of Ukraine, disciplinary action is applied by the owner or his/her authorized body immediately after the misdemeanour, but not later than one month from the date of its discovery, without taking into account the time of dismissal of the employee from work due to temporary incapacity or leave. Furthermore, it cannot be imposed after 6 months from the date of the offense.

According to the requirements of Art. 149 of this Code, before making a decision on dismissal of the head for onetime gross breach of work duties, he/she is required to provide written explanations. The purpose of obtaining them by the employer is to find out the circumstances wherein the misdemeanour has been committed to take this into account along with other circumstances, when choosing the type of action. The fact that the owner or his/her authorized body did not receive such explanations due to the lack of data on the seriousness of the reasons for the breach cannot be grounds for declaring the decision to apply a disciplinary action unlawful.

It is not possible to dismiss for breach that has already entailed another type of disciplinary actions. However, when an employee causes property damage, a combination of disciplinary and pecuniary liability is possible, as these actions have different purposes.

According to E. Antsut, dismissal of an employee under para. 1 of Part 1 of Art. 41 of the LC of Ukraine requires indication, in the decision, order (ordinance) of the competent authority or owner, both the factual and legal grounds for dismissal for breach, as well as the provision of the $\mathrm{LC}^{1}$.

1 Antsut, E. Dismissal of the head for one-time gross breach work duties. Pratsya i Zakon, 3 (159), 2013: 20. 
According to Art. 43-1 of the LC of Ukraine, termination of an employment contract at the initiative of the owner or his/her authorized body in case of one-time gross breach of labour duties is allowed without the consent of the elected body of the primary trade union organization (trade union representative).

The requirement that dismissal occurs, if it is impossible to transfer the employee to another job with his/her consent, does not apply to the specified grounds for termination of employment. The requirement of part 3 of Art. 40 of this Code, which does not allow a dismissal of the employee during his/her temporary incapacity for work, or on leave, applies to the considered ground of termination of the employment contract. Therefore, considering the specificity of the legal status of persons who may be dismissed under para. 1 of Part 1 of Art. 41 of the LC of Ukraine, the list of periods when employees cannot be dismissed should be expanded providing that disciplinary action in the form of dismissal does not apply: a) in case of absence of the employee at work due to temporary incapacity for work; b) during the stay of employees on leave or business trip; c) during an official investigation.

Severance pay is not paid to employees dismissed for onetime gross breach of work duties.

The results of a comprehensive study in this sub-section of the monograph enable to make conclusions of significant theoretical and applied significance.

1. One-time gross breach of work duties is a type of breach of labour discipline by an employee, therefore, the law application body should establish more specifically what this breach was, whether it could be grounds for termination of the employment contract under para. 1 of Art. 41 of the LC of Ukraine and which legal requirements regarding timing and procedure for applying disciplinary actions should be observed. 
2. The law application body can find breach of work duties gross, based on the nature of a misdemeanour, circumstances whereby it was committed, the damage caused or could have been caused by the employee. Moreover, this should be onetime, not ongoing breach of work duties, which may entail the application of disciplinary actions on other grounds. In other words, if breach is long-term (for example, weakening or lack of control over the work of subordinates), and is not one-time, the dismissal under para. 1 of Art. 41 of the LC of Ukraine is impossible.

3. The list of periods when employees cannot be dismissed should be expanded providing that corresponding disciplinary action does not apply: a) in case of absence of the employee at work due to temporary incapacity for work; b) during the stay of employees on leave or business trip; c) during an official investigation.

4. Termination of the employment contract in case of one-time gross breach of work duties should be clearly distinguished from termination of the employment contract with the head at the request of the elected body of the primary trade union organization (trade union representative). The key differences between termination of the employment contract in the cases provided for in para. 1 of Part 1 of Art. 41 of the LC and Art. 45 of the LC are as follows:

a) the former occurs at the initiative of the employer, while the initiator of the latter is the elected body of the primary trade union organization (trade union representative);

b) the first is the ground for dismissal of the head of the enterprise or a separate division, his/her deputies, the chief accountant of the enterprise, his/her deputies, as well as officials of the revenue and duties bodies nominated for special ranks, and officials of central executive bodies implementing national policy in public financial control and price control, and the second - only of the head of the legal entity; 
c) the ground for termination of the employment contract in the first case is one-time gross breach of work duties, in the second - breach of laws on labour, collective agreements and contracts, the Law of Ukraine "On trade unions, their rights and guarantees of activity". In the second case, breaches concern labour rights and guarantees of their provision for all or most employees of the enterprise;

d) dismissal on the first ground is a disciplinary action, and on the second, it is not such an action;

e) in the first situation, dismissal is the right of the employer, who may not use it, in the second, the latter is obliged to terminate the employment contract.

\section{Conclusions to Chapter 3}

The study of the current state of affairs in legal regulation of termination of the employment contract in case of onetime gross breach of work duties enabled to make certain scientific and theoretical conclusions and formulate author's proposals regarding improvement of this procedure.

1. Therefore, there are no laws and logic in the separation by the legislator of revenue and duties officials, nominated for special ranks, as well as officials of central executive bodies implementing national policy in public financial control and price control, as subjects of dismissal for onetime gross breach of work duties. Moreover, this step of the legislator seems to have no proper and weighty justification. For example, it is unclear why the subjects, covered by paragraph 1 of Art. 31 the LC of Ukraine, involve officials of the State Financial Inspection of Ukraine, while officials of the State Treasury Service of Ukraine or the State Service of Financial Monitoring of Ukraine are not included in this category. Although, it would seem, the objectives performed by these three public institutions are somehow 
similar, as well as the powers entrusted to them. In addition, the separation of officials of the central executive body, which implements the national policy in the field of price control, does not correspond to the current situation, after all, on September 10, 2014, in order to optimize the system of central executive bodies and in accordance with paragraphs 9 and 9-1 of Art. 116 of the Constitution of Ukraine, the Cabinet of Ministers of Ukraine decided to liquidate the State Inspectorate for Price Control, entrusting the functions of monitoring the dynamics of prices (tariffs) in the consumer market to the State Statistics Service. Under these circumstances and in view of the experience of foreign countries, it seems prudent to extend the scope of para. 1 of Art. 41 of the LC of Ukraine to officials of the sectors of the economy subject to Statutes on discipline (prosecutor's offices, railways, mining companies, etc.).

Moreover, it should be noted that the Constitutional Court of Ukraine in the case of legal entities' liability came to the conclusion that in accordance with para. 22 of Part 1 of Art. 92 of the Constitution of Ukraine, only the laws should regulate both the principles of civil, criminal, administrative and disciplinary liability, i.e. acts that are crimes, administrative or disciplinary offenses (that have main features of offenses, which form their elements), and liability for these offenses.

2. To ensure accounting, the enterprise independently chooses the forms of its organization, including the introduction of the position of an accountant in the company's staff or the creation of an accounting department headed by the chief accountant. According to the Qualification characteristics of occupations of workers, approved by Order of the Ministry of Labour and Social Policy of Ukraine No. 336 of 29 December 2004, a chief accountant manages the accounting staff of the enterprise, distributes among them job missions and duties, acquaints them with regulatory and methodological documents and information 
materials related to their activities, as well as with changes in current legislation. At the same time, according to the Classifier of Occupations DK 003:2010, approved by Order of State Committee of Ukraine for Technical Regulation and Consumer No. 327 of 28 July 2010, the occupational title of the position "Chief Accountant" under the Classifier code (code 1231) belongs to the occupational group "Heads of financial, accounting, economic, legal and administrative divisions and other heads". Therefore, the introduction of the position of a chief accountant in the staff list of the enterprise is possible in case of creating an appropriate structural division. Based on the fact that most enterprises in Ukraine are small, that to ensure accounting, they are often limited to the introduction in the staff only a position of an accountant, rather than the creation of an accounting department headed by the chief accountant, therefore, according to Art. 8 of the Law "On accounting and financial reporting in Ukraine”, para. 1 of Art. 41 of the LC of Ukraine should cover not only the chief accountants of enterprises, institutions, organizations, their deputies, but also the persons responsible for accounting of the business entity.

3. The successful operation of the enterprise in general, as well as the successful performance of each member of its workforce, requires significant efforts to organize them, to determine the target, coordination of their actions, i.e. requires relevant management. The management is to some extent an independent activity that involves the ability to influence individual employees and the team in general so that they work towards achieving the goals and objectives of a particular division or the whole entity for its effective functioning.

Under modern conditions, the key requirement for the head is the ability to overcome challenges emerging in economic practice, contradictions between state and collective interests and the ability to reconcile them, adhering 
to the priority of common human interests in economic issues, where the key form of such activities is a managerial decision, its preparation, adoption and implementation, for which the head should be responsible. The effectiveness of his/her performance is assessed by the indicators as follows: (a) his/her work team productivity, (b) the success of occupational tasks, (c) the proper psychological climate in the team, (d) employee health in the absence of injury, (e) turnover of personnel, etc.

The issue of whether the head of the structural division of a legal entity belongs to employees with whom the employment contract can be terminated due to one-time gross breach of work duties, requires considering both property and territorial separation of the division headed by him/her, as well as the fact that according to Art. 64 of the Economic Code of Ukraine, the enterprise has the right to create suboffice, representative office, branch, other separate division, coordinating issues as to their location with relevant local governments. Provisions of the Civil Code of Ukraine do not prevent legal entities from creating separate divisions not only in other settlements, but also in the same settlement where the legal entity is located. It is only important that this division is property-separated. Such divisions do not have the legal entity status, and act on the basis of a relevant provision, approved by an enterprise. The person who heads such division and performs organizational and administrative functions have the status of "the head of a separate division."

4. The possibility of terminating the employment contract at the initiative of the employer with the head of the legal entity or a separate structural division, his/her deputies, the chief accountant, his/her deputies, officials responsible for accounting, as well as with officials, covered by Statutes on discipline requires legislative consolidation. An approximate version of this provision is formulated. 
5. One-time gross breach of work duties is a type of breach of labour discipline by an employee, therefore, the law application body should establish more specifically what this breach was, whether it could be grounds for termination of the employment contract under para. 1 of Art. 41 of the LC of Ukraine and which legal requirements regarding timing and procedure for applying disciplinary actions should be observed.

6. The law application body can find breach of work duties gross, based on the nature of a misdemeanour, circumstances whereby it was committed, the damage caused or could have been caused by the employee. Moreover, this should be onetime, not ongoing breach of work duties, which may entail the application of disciplinary actions on other grounds. In other words, if breach is long-term (for example, weakening or lack of control over the work of subordinates), and is not one-time, the dismissal under para. 1 of Art. 41 of the LC of Ukraine is impossible.

7. The list of periods when employees cannot be dismissed should be expanded providing that corresponding disciplinary action does not apply: a) in case of absence of the employee at work due to temporary incapacity for work; b) during the stay of employees on leave or business trip; c) during an official investigation.

8. Termination of the employment contract in case of one-time gross breach of work duties should be clearly distinguished from termination of the employment contract with the head at the request of the elected body of the primary trade union organization (trade union representative). The key differences between termination of the employment contract in the cases provided for in para. 1 of Part 1 of Art. 41 of the LC and Art. 45 of the LC are as follows:

a) the former occurs at the initiative of the employer, while the initiator of the latter is the elected body of the primary trade union organization (trade union representative); 
b) the first is the ground for dismissal of the head of the enterprise or a separate division, his/her deputies, the chief accountant of the enterprise, his/her deputies, as well as officials of the revenue and duties bodies nominated for special ranks, and officials of central executive bodies implementing national policy in public financial control and price control, and the second - only of the head of the legal entity;

c) the ground for termination of the employment contract in the first case is one-time gross breach of work duties, in the second - breach of laws on labour, collective agreements and contracts, the Law of Ukraine "On trade unions, their rights and guarantees of activity". In the second case, breaches concern labour rights and guarantees of their provision for all or most employees of the enterprise;

d) dismissal on the first ground is a disciplinary action, and on the second, it is not such an action;

e) in the first situation, dismissal is the right of the employer, who may not use it, in the second, the latter is obliged to terminate the employment contract. 


\section{CONCLUSIONS}

The monograph provides a theoretical generalization and an original response to the scientific challenges, that is, the analysis of scientific and theoretical achievements of legal scholars the study of international legal standards, review of national and foreign legislation enable to formulate a number of conclusions and proposals with regard to establishing the legal nature of gross breach of work duties by an employee, determining of their place in the system of additional grounds for termination of the employment contract at the initiative of the employer, clarifying the current status of regulatory and legal application and practice in this field, as well as with regard to preparing recommendations for improvement. The following most important conclusions are made.

1. Work duties of the worker as a party to the employment relationship is a system of requirements defined by legislative and local acts in the field of labour regarding specified behaviour of the employee in the course of the work under the employment contract, due to the interests of the employer and state-guaranteed coercive measures. The system of work duties of employees includes:

a) general work duties for all without exception, employees, regardless of the legal status, ownership, industry affiliation, subordination and other features of employers for whom they work under an employment contract;

b) special sectoral ones for workers covered by employed in enterprises, institutions and organizations engaged in a particular type of economic activity in the sectors of tangible or intangible production; 
c) direct production and functional ones for the worker within his/her employment function by the employer in accordance with the employment contract concluded between them.

2. The essential features of the category "gross breach of work duties" as a labour law phenomenon include: (a) this breach has caused or could cause substantial pecuniary and non-pecuniary damage to the rights or interests of employees, employers or the State; (b) this category is an evaluative concept; (c) subjects of this breach are special categories of employees defined by law; (d) this offense is a disciplinary misdemeanour; breach can entail dismissal of the employee at the initiative of the employer.

3. Gross breach of work duties is the unlawful conduct of categories of workers defined by law, as a result of which other workers of the enterprise, institution, organization, the employer or the State have suffered or could have suffered substantial pecuniary and non-pecuniary damage; and which may entail the application, in the prescribed manner, of disciplinary action, including dismissal, to the guilty person. Scientific and regulatory approaches to a legislative and scientific-theoretical distinction into one-time gross breach of work duties by employees in general and individual categories of workers (the head of the organization (sub-office, representative office), his deputies, officials who are subject to the requirements of disciplinary statutes, etc.), as well as to recognition of all cases of one-time commission of unlawful behaviour by these persons, which can entail dismissal at the initiative of the employer, as gross breach of work duties by workers, are inappropriate. This due to the fact that it implies a substitution of categories, a basis for confusion and, in the end, law application suffers. More logical and balanced further use of two legal categories (both in labour law study and in labour law) should be as follows: (a) one-time 
substantive breach of work duties, in relation to employees in general and (b) one-time gross breach of work duties, in relation to special categories of workers.

4. In order to specify the evaluative concept of "gross breach of work duties," and therefore to facilitate the law application, it should be legislated that gross breach of work duties occurs in the cases when pecuniary damage caused by illegal behaviour of the worker exceeds a certain minimum legally fixed (for example, 10 minimum wages), and non-pecuniary one - if the violation of rights and interests not only led to moral suffering, loss of normal life connections and for additional efforts to organize the life of an individual employee, but also caused a deterioration of the image and credibility of an individual enterprise, institution or organization and the relevant service in general.

It is not contrary to the current labour law if the evaluative concept under study is specified directly in the local acts of the enterprise or in the employment contract by stating the specificities established, such as (a) losses incurred by the employer, payment of fines; (b) breach of law in financial utilization; (c) failure to pay taxes, fees and mandatory payments; (d) breach of the procedure for settlements; (e) permitting of growth of overdue accounts payable; (f) failure to submit financial statements.

5. Formation and development of legal regulation for termination of the employment contract in the case of onetime gross breach by the employee of his/her labour duties includes 3 key periods: (a) 1928-1969; (b) 1970-1990 and (c) 1991- to the present. The key features of each of these stages are singled out.

6. In the world two key approaches to the legal regulation of labour activity of the head of the organization: (a) in the countries of the Anglo-Saxon law the head is not considered as an employee, but is outside the scope of labour 
law and performs his/her functions on the basis of a contract of a civil nature. As a result, the use of the labour law term "dismissal" in relation to such subjects is inappropriate. Termination of employment relationship occurs at the discretion of the owner of the organization on the grounds specified in the civil contract; (b) in the countries of the continental law the head, considering the work function he/she performs and duties assigned to him/her, has the status of an employee, though specific.

If the head of the organization is considered as a subject of labour law, the possibility of this dismissal in case of onetime gross breach of work duties is provided for either by (a) provisions of the Labour Code of the country and other legal regulations containing provisions of labour law (post-Soviet states), or (b) the terms and conditions of the individual employment contract (Bulgaria, Estonia, Latvia, Germany, the Czech Republic and others).

The labour legislation of foreign countries recognizes mainly the head of the organization and his/her deputies as the subject of termination of the employment contract at the initiative of the employer in case of one-time gross breach of work duties. Occasionally, they include the heads of separate structural units (their deputies), chief accountants (their deputies), employees covered by statutes and regulations on discipline. Although the construction "gross breach of work duties" is evaluative and remains at the discretion of the court, employer or other law applier, legal regulations or individual employment contracts often provides for interpretations of its use. The grounds for dismissal cannot be non-performance of any actions, which are not duties of the subjects of dismissal.

7. Therefore, there are no laws and logic in the separation by the legislator of revenue and duties officials, nominated for special ranks, as well as officials of central executive bodies implementing national policy in public 
financial control and price control, as subjects of dismissal for one-time gross breach of work duties. Moreover, this step of the legislator seems to have no proper and weighty justification. For example, it is unclear why the subjects, covered by paragraph 1 of Art. 31 the LC of Ukraine, involve officials of the State Financial Inspection of Ukraine, while officials of the State Treasury Service of Ukraine or the State Service of Financial Monitoring of Ukraine are not included in this category. Although, it would seem, the objectives performed by these three public institutions are somehow similar, as well as the powers entrusted to them. In addition, the separation of officials of the central executive body, which implements the national policy in the field of price control, does not correspond to the current situation, after all: on September 10, 2014, in order to optimize the system of central executive bodies and in accordance with paragraphs 9 and 9-1 of Art. 116 of the Constitution of Ukraine, the Cabinet of Ministers of Ukraine decided to liquidate the State Inspectorate for Price Control, entrusting the functions of monitoring the dynamics of prices (tariffs) in the consumer market to the State Statistics Service.

Under these circumstances and in view of the experience of foreign countries, it seems prudent to extend the scope of para. 1 of Art. 41 of the LC of Ukraine to officials of the sectors of the economy subject to Statutes on discipline (prosecutor's offices, railways, mining companies, etc.).

8. The introduction of the position of a chief accountant in the staff list of the enterprise is possible in case of creating an appropriate structural division. Based on the fact that most enterprises in Ukraine are small, that to ensure accounting, they are often limited to the introduction in the staff only a position of an accountant, rather than the creation of an accounting department headed by the chief accountant, therefore, according to Art. 8 of the Law "On accounting 
and financial reporting in Ukraine”, para. 1 of Art. 41 of the LC of Ukraine should cover not only the chief accountants of enterprises, institutions, organizations, their deputies, but also the persons responsible for accounting of the business entity.

9. The issue of whether the head of the structural division of a legal entity belongs to employees with whom the employment contract can be terminated due to onetime gross breach of work duties, requires considering both property and territorial separation of the division headed by him/her, as well as the fact that according to Art. 64 of the Economic Code of Ukraine, the enterprise has the right to create suboffice, representative office, branch, other separate division, coordinating issues as to their location with relevant local governments. Provisions of the Civil Code of Ukraine do not prevent legal entities from creating separate divisions not only in other settlements, but also in the same settlement where the legal entity is located. It is only important that this division is property-separated. Such divisions do not have the legal entity status, and act on the basis of a relevant provision, approved by an enterprise. The person who heads such division and performs organizational and administrative functions have the status of "the head of a separate division.

10. One-time gross breach of work duties is a type of breach of labour discipline by an employee, therefore, the law application body should establish more specifically what this breach was, whether it could be grounds for termination of the employment contract under para. 1 of Art. 41 of the LC of Ukraine and which legal requirements regarding timing and procedure for applying disciplinary actions should be observed. The law application body can find breach of work duties gross, based on the nature of a misdemeanour, circumstances whereby it was committed, the damage caused or could have been caused by the employee. Moreover, this 
should be one-time, not ongoing breach of work duties, which may entail the application of disciplinary actions on other grounds. In other words, if breach is long-term (for example, weakening or lack of control over the work of subordinates), and is not one-time, the dismissal under para. 1 of Art. 41 of the LC of Ukraine is impossible.

11. Disciplinary action does not apply: a) in case of absence of the employee at work due to temporary incapacity; b) during the stay of employees on leave or business trip; c) during an official investigation.

12. The key differences between termination of the employment contract in the case of one-time gross breach of work duties (para. 1 of Part 1 of Art. 41 of the LC) and termination of the employment contract with the head at the request of the elected body of the primary trade union organization (trade union representative) (Art. 45 of the LC of Ukraine) are:

a) the former occurs at the initiative of the employer, while the initiator of the latter is the elected body of the primary trade union organization (trade union representative);

b) the first is the ground for dismissal of the head of the enterprise or a separate division, his/her deputies, the chief accountant of the enterprise, his/her deputies, as well as officials of the revenue and duties bodies nominated for special ranks, and officials of central executive bodies implementing national policy in public financial control and price control, and the second - only of the head of the legal entity;

c) the ground for termination of the employment contract in the first case is one-time gross breach of work duties, in the second - breach of laws on labour, collective agreements and contracts, the Law of Ukraine "On trade unions, their rights and guarantees of activity”. Moreover, in the second case, breaches concern labour rights and guarantees of their provision for all or most employees of the enterprise; 
One-time gross breach of work duties as the ground for termination of the employment contract at the initiative of the employer

d) dismissal on the first ground is a disciplinary action, and on the second, it is not such an action;

e) in the first situation, dismissal is the right of the employer, who may not use it, in the second, the latter is obliged to terminate the employment contract. 


\section{REFERENCESS}

1. Syrovatskaia, L. A. Labor law. 2nd ed. M.: Yurist, 1998. 312 p.

2. Lazarev, V. V. Gaps in law and ways to address them. M.: Yurid. lit., 1974. 263 p.

3. Zagainova, S. K. Judicial precedent: Problems of law application. M.: NORMA, 2002. 176 p.

4. Yaroshenko, O. M. Sources of Labour Law of Ukraine. Doctor's thesis. Yaroslav Mudryi National Law University. Kh., 2007. $476 \mathrm{p}$.

5. Bazhanova, P. B. Commercial organizations and entrepreneurs without the formation of a legal entity as subjects of Labour Law. Ph.D.'s thesis. Academy of Labour and Social Relations. M., 2004. 208 p.

6. Khutoryan, N. M., Inshyn, M. I., Prylypko, S. M., Yaroshenko, O. M. (Eds). Codification of the labour legislation of Ukraine. Kh.: FINN, 2009. 432 p.

7. Slusar, A. M. The subjects of Labour Law of Ukraine. Doctor's thesis. Yaroslav Mudryi National Law University. Kh., 2011. $407 \mathrm{p}$.

8. Constitution of Ukraine. (No. 254k/96-VR of 28 June 1996). Vidomosti Verkhovnoi Rady Ukrainy, no. 30, 1996. Art. 141.

9. Andriiv, V. M. The system of labour rights of employees and the mechanism of their provision. Extended abstract of Doctor's thesis. National University Odessa Law Academy. O., 2012. $40 \mathrm{p}$.

10. Lazor, V. V. Problems of definition of the concept and legal status of the subjects of labour law in the modern labour legislation of Ukraine. In Actual Problems of Law: Theory and Practice, 8, 2006: 22-30. Luhansk: V. Dahl EUNU.

11. Romashov, O. V. Sociology of labour. M.: Gardarika, 2001. 320 p.

12. Akopova, E. M. The modern labour agreement (contract). Rostov: Mart, 1998. 352 p. 
One-time gross breach of work duties as the ground for termination of the employment contract at the initiative of the employer

13. Protsevskyi, O. I. The new content of the right to work is the basis of reforming the labour legislation of Ukraine. Pravo Ukrainy. 1999. No. 6. P. 101-105.

14. Protsevskyi, A. I. The subject of Soviet Labour Law. M.: Yurid. lit., 1979. 209 p.

15. Aleksandrov, N. G. Soviet Labour Law. 3rd ed. M.: Gosyurizdat, 1963. $414 \mathrm{p}$.

16. Purei, M. M. The right to work in Ukraine under market economy. Ph.D.'s thesis. H. S. Skovoroda Kharkiv State Pedagogical University. Kh., 2002. 173 p.

17. Chanysheva, H. I. Collective relations in the sphere of labour: Theoretical and legal aspect. A.: Yuryd. lit. 2001, 280 p.

18. Ginzburg, L. Ya. Socialist Labour Relations. M.: Nauka, 1977. $310 \mathrm{p}$.

19. ILO Recommendation on employment relations No. 198. (May 31, 2006). Retrieved from http://zakon4.rada.gov.ua/laws/ show/993_529.

20. Sychov, D. V. Legal regulation of individual labour relationship. Ph.D.'s thesis. National University of Internal Affairs. Kh., 2005. $182 \mathrm{p}$.

21. Smirnov, O. V. (Ed.). Labour Law. M.: Prospect, 1997. 448 p.

22. Matsiuk, A. R. Labour relations of a developed socialist society. K.: Naukova dumka, 1984. 280 p.

23. Krasnov, Ye. V. Basic labour rights: International standards and legislation of Ukraine. Odessa National Law Academy. O., 2008. $206 \mathrm{p}$.

24. Matuzov, N. I. Legal system and personality. Saratov: Saratov University, 1987. $294 \mathrm{p}$.

25. Chernykh, Ye. M. Objective and subjective law: Theoretical and legal aspects of correlation. Ph.D.'s thesis. Kyiv National University of Internal Affairs. K., 2008. 235 p.

26. Prylypko, S. M., Yaroshenko, O. M., Zhyhalkin, I. P. et al. Labour Law of Ukraine. 5th ed. Kh.: Pravo, 2014. 760 p.

27. Labour Code of Ukraine approved by Law of the USSR No. 322-VIII of 10 December 1971. Vidomosti Verkhovnoi Rady of the USSR, no. 50 (Appendix). 1971. Art. 375. 
One-time gross breach of work duties as the ground for termination of the employment contract at the initiative of the employer

28. Draft Labour Code of Ukraine (Registration No. 1658 of 27 December 2014). Retrieved from http://w1.c1.rada.gov.ua/pls/zweb2/webproc4_1?pf3511=53221.

29. Grotius, H. On the Law of War and Peace. Three books explaining natural law and the law of peoples, as well as the principles of Public Law. M.: Ladomir, 1994. 848 p.

30. Rousseau, J.-J. On a social contract, or Principles of political law. M.: Politizdat, 1969.

31. Kelsen, H. Pure Theory of Law. K.: University, 2004. 496 p.

32. Kotaleichuk, S. P. Theoretical and legal issues of underage persons' legal status in Ukraine and ensuring its realization as one of the main areas of police activity. Ph.D.'s thesis. National Academy of Internal Affairs. K., 2004. 235 p.

33. Kovalskyi, V. Security function of the State as a system. Yurydychna Ukraina, no. 11, 2003: 26-30.

34. Tzurikov, M. O. The system of transactions subject to public registration. Ph.D.'s thesis. Yaroslav Mudryi National Law University. Kh., 2011. 223 p.

35. Syrovatskaya, L. A. Responsibility for violation of labour legislation. M.: Yurid. lit., 1990.175 p.

36. Economic Code of Ukraine (approved by Law of Ukraine no. 436-IV of 16 January 2003). Vidomosti Verkhovnoi Rady Ukrainy, no. 18-22, 2003. Art. 144.

37. Classification of Economic Activities DK 009:2010. (Approved by the Order of the State Committee of Ukraine for Technical Regulation and Consumer Policy No. 457 of 11 October 2010). Retrieved from http://search.ligazakon.ua/__doc2.nsf/link1/ FIN19567.html.

38. Order of the State Statistics Committee of Ukraine on approval of methodological provisions for determining the main type of economic activity of the enterprise No. 607 of 14 December 2006. Retrieved from http://search.ligazakon.ua/1_doc2.nsf/ link1/FIN25473.html.

39. Law of the USSR on Education No. 1060-XII of May 23, 1991. Vidomosti Verkhovnoi Rady of the USSR, no. 34, 1991. Art. 451.

40. Law of Ukraine on Higher Education No. 1556-VII of 1 July 2014. Vidomosti Verkhovnoi Rady Ukrainy, no. 37-38, 2014. Art. 2004. 
One-time gross breach of work duties as the ground for termination of the employment contract at the initiative of the employer

41. Law of Ukraine on Public service No. 3723-XII of 16 December 1993. Vidomosti Verkhovnoi Rady Ukrainy, no.52, 1993. Art. 490.

42. Inshyn, M. I., Shcherbyna, V. I. (Eds.) Labour Law. Kh.: Nika Nova, 2012. 560 p.

43. Zhernakov, V. V., Eremenko, V. V. On the concept and content of the labour function. In Issues of firming social legality and the rule of law, strengthening the protection of the rights and legitimate interests of citizens in the context of restructuring socialistic society. K.: UMK VO, 1989: 61-65.

44. Order of the State Judicial Administration on approval of the standard job description of chief media relation specialist (spokesperson) No. 145 of 06 November 2013. Retrieved from http://dsa.court.gov.ua/dsa/ 14/4564563khgkjgg/.

45. Resolution of the Plenum of the Supreme Court of Ukraine on the practice of consideration of labour disputes by courts No. 9 of 06 November 1992. Biuleten zakonodavstva $i$ yuridicheskoi praktiki Ukrainy, no. 2, 2006: 154.

46. Cherdantsev, A. F. Logic-linguistic phenomena in jurisprudence. M.: Norma: INFRA-M, 2012. 320 p.

47. Apt, L. F. Legal definitions in the legislation. In Problems of legal technics. V. M. Baranova (Ed.). Nizhny Novgorod, 2000: 301-315.

48. Ushakova, Yu. A. Concept, content and forms of ownership. Ph.D.'s thesis. I. Franko Lviv National University. Lviv, 2011. $224 \mathrm{p}$.

49. Dresviankin, V. B. Gaps in the Russian Labour Law. Ph.D.'s thesis. Perm State University, Perm, 2001. 163 p.

50. Malein, N.S. Compensation for damage caused to a person. M.: Yurid. lit., 1965. 228 p.

51. Sevriugin, V. E. The concept of an offense under administrative law. M.: Gosyurizdat, 1988. 216 p.

52. Malein, N.S. Delinquency: Concept, reasons, responsibility. M.: Yurid. lit., 1985. 192 p.

53. Law of Ukraine on labour protection No. 2694-XII: of 14.10.1992. Vidomosti Verkhovnoi Rady Ukrainy, no. 49, 1992: 668.

54. Karpenko, D. O. Fundamentals of Labour Law. K.: A.S.K., 2003. $656 \mathrm{p}$. 
One-time gross breach of work duties as the ground for termination of the employment contract at the initiative of the employer

55. Obushenko, O. M. Legal regulation of labour protection in Ukraine. K.: Hi-Tech Press, 2014. 372 p.

56. Resolution of the Cabinet of Ministers of Ukraine on the procedure for attestation of workplaces under working conditions No. 442 of 01 August 1992. Retrieved from http://zakon1.rada.gov.ua/laws/show/ 442-92-\%D0\%B.

57. Methodical recommendations for attestation of workplaces under working conditions (approved by Resolution of Ministry of Labour of Ukraine No. 41 of 01 September 1992). Ukr. Invest. Gas, no. 28, 2008.

58. Code of Ukraine on Administrative Offenses (approved by Law of Ukraine No. 8073-X of December 7, 1984). Vidomosti Verkhovnoi Rady USSR, No. 51, 1984. (Appendix). Art. 1122.

59. Chernous, S. M. Evaluative concepts in Labor Law of Ukraine. Ph.D.'s thesis. T. Shevchenko Kyiv National University. K., 2008. $212 \mathrm{p}$.

60. Lazarev, V. V. Application of Soviet law. Kazan: Kazan University, 1972. $200 \mathrm{p}$.

61. Baru, M. I. Evaluative concepts in labor legislation. Soviet State and Law, no. 7, 1970: 104-108.

62. Kobzeva, E. V. Evaluative features in criminal law. Saratov: SEI HVE Saratov State Acad. Law, 2004. 228 p.

63. Stepanova, E. A. Evaluative concepts of Labor Law. Ph.D.'s thesis. Rostov State Un-ty. Rostov, 2005. 187 p.

64. New Explanatory Dictionary of Ukrainian Language. In 3 vols. (Vol. 3: A - K; 2nd ed.). V. V. Yaremenko, A. M. Slipushko (Eds.). K.: Akonit, 2008. 926 p.

65. Ozhegov, S. I. Explanatory dictionary of the Russian Language. (80000 words and phraseological expressions; 4th ed). S. I. Ozhegov, N. Yu. Shvedova (Eds.) M.: Ltd A TEMP, 2006. 944 p.

66. Voplenko, N. N. Official interpretation of provisions of law. M.: Yurid. lit., 1976. 118 p.

67. Shmeleva, G. G. Specification of legal provisions in legal regulation. Lviv: Higher school, 1988. $104 \mathrm{p}$.

68. Vlasov, Yu. L. Problems of interpretation of provisions law. Extended abstract of Ph.D.'s thesis. ISL NAS of Ukraine. K., 2000. 17 p. 
One-time gross breach of work duties as the ground for termination of the employment contract at the initiative of the employer

69. Pryima, S. V. Principles of interpretation of provisions of law. Ph.D.'s thesis: Yaroslav Mudryi National Law University. Kh., 2010. 194 p.

70. Petrishin, A. V. Civil service. Historical and theoretical preconditions, comparative legal and logical-conceptual analysis. Kharkov: Fakt, 1998. 168 p.

71. Law of Ukraine on prevention of corruption No. 1700-VII of 14 October 2014. Ofitsiinyi visnyk Ukrainy, no. 87, 2014. Art. 2474.

72. Duiunova, O. M. Labor agreements under the labor legislation of Ukraine. Ph.D.'s thesis. T. Shevchenko Kyiv National University. K., 2003. $194 \mathrm{p}$.

73. Yusypiuk, I. Contract is stylish. But is it effective? Pravovyi tyzhden, no. 50 (71), 2007: 6.

74. Resolution of the Cabinet of Ministers of Ukraine regarding Standard form of the contract with the head of the state-owned enterprise No. 597 of 2 August 1995. Ukr. Invest. Gas, no. 50, 2007: 286.

75. Letter from the State Property Fund of Ukraine regarding Contracts with the Chairman of the Board of the Open Joint Stock Company No. 10-17-11495 of 05 November 1999. Biul. pro pryvatyzatsiu, no. 1, 2000: 250.

76. Labour Code of Turkmenistan (approved by Law of Turkmenistan No. 30-IV of 18 April 2009). Vedom. Medzhlisa Turkmenistana, no. 2 (996), Part 4, 2009: 30.

77. Labour Code of the Russian Federation (approved by Law of the RF No. 197-FZ of 30 December 2001). Collection of RF legislation, no. 1, Part 1, 2002: 3.

78. Labour Code of the Transnistrian Moldavian Republic (Law of Transnistrian Moldavian Republic No. 161-3-III of 19 July 2002). Retrieved from http://www.minjust.org/ web.nsf/767eb8a58ad76a 2bc22574d5002acf15/6b93855 f22f2898ac22575d70030046d.

79. Labour Code of the Kyrgyz Republic (approved by Law the Kyrgyz Republic No. 106 of 04 August 2004. Vedom. Zhogorku Kenesha Kyrgyzskoy Resp., no. 4, 2006: 392. 
One-time gross breach of work duties as the ground for termination of the employment contract at the initiative of the employer

80. Labour Code of the Republic of Armenia Law Resp. Armenia No. HO-124 of 9 November 2004. Ofits. vedom. (vestn.) Resp. Armenia, no. 69(368), 2004. Art. 1385.

81. Law of Ukraine on the Disciplinary Statute of the bodies of Internal Affairs of Ukraine No. 3460-IV of 22 February 2006. Vidomosti Verkhovnoi Rady Ukrainy, no. 29. 2006. Art. 245.

82. Kapitanska, S. A. Legitimate inactivity as a form of legal conduct. Ph.D.'s thesis. National Academy of Internal Affairs. K., 2005. $220 \mathrm{p}$.

83. Poletaev, Yu. N. Law and responsibility in Labour Law. M.: Prospekt, 2001. 184 p.

84. Skakun, O. F. Theory of state and law. Kharkov: Konsum, 2000. $704 \mathrm{p}$.

85. Bugaichuk, K. L. Administrative misdemeanour: Essence and organizational-legal actions of their prevention. Ph.D.'s thesis. National University of Internal Affairs. Kh., 2002. 243 p.

86. Kovryhin, V. S. Disciplinary liability in Labour Law. Ph.D.'s thesis. T. Shevchenko Kyiv National University. K., 2012. 221 p.

87. Yoffe, O. S. and Shargorodskii, M. D. Issues of the theory of law. M.: Yurid. lit., 1961. 421 p.

88. Bratus, S. N. Legal liability and legality. M.: Yurid. Lit., 1976. $311 \mathrm{p}$.

89. Popov, V. I. Legal liability of workers and employees under Soviet Labour Law. Extended abstract of Ph.D.'s thesis. Sverdlovsk Law Institute. Sverdlovsk, 1974. $20 \mathrm{p}$.

90. Veremeenko, I. I. Administrative and legal actions. M.: Yurid. lit., 1975. $180 \mathrm{p}$.

91. Tolkunova, V. N. Labour Law. M.: Prospect, 2004. - 651 p.

92. Pylypenko, P. D. Labour Law of Ukraine. L.: Vilna Ukraina, 1996. 159 p.

93. Gurevich, A. Ya. Th theory of formations and the reality of history. Vopr. Filosofii, no. 11, 1996: 31-43.

94. Vostroknutov, L. D. Genesis and development of legal provisions in the field of physical culture and healthy lifestyle of the Ukrainian people: From customary law to the legislation of the early twentieth century. Ph.D.'s thesis. National University of Internal Affairs. Kh., 2003. 211 p. 
One-time gross breach of work duties as the ground for termination of the employment contract at the initiative of the employer

95. Lukyanets, V. Science in the interior of postmodernism. Filos. Dumka, no. 1, 2005: 3-22.

96. Reznik, O. I. Periodization of the historical and legal process: Conceptual aspects. Ph.D.'s thesis. Odessa National Law Academy. O., 2008. 190 p.

97. Balabanov, M. (Eds.). Factory laws: Collection of laws, orders and clarifications on issues of Russian industrial legislation. K.: Pechat. delo, 1905. 140 p.

98. Tal, L. S. Labour contract. Civilistic research. Part 1: General teachings. Yaroslavl: Gubern. Pravleniia. 1913. 422 p.

99. Butovskii, N. D. Essays on the Modern Officer Life. St. Petersburg: N. K. Garshin, 1899. 215 p.

100. Vasiliev, D. A. Factory legislation of Russia at the end of the 19 th - beginning of the 20th centuries. Ph.D.'s thesis. Academy of Labour and Social Relations. M., 2001. 155 p.

101. Labour Code of the RSFSR (approved by Resolution of ARCEC of 10 December 1918). The Collection of Laws and Orders of the Workers and Peasants' Government of the RSFSR No. 87-88, 1918. Art. 905.

102. Labour Code Laws of the USSR (approved by Resolution of AUCEC of 02 December 1922). The Collection of Laws of the USSR No. 52, 1922. Art. 751.

103. Regulation on disciplinary liability by subordination (approved by Resolution of ACEC and the CPC of the USSR of 17 October 1928). SU USSR, no. 29, 1928. Art. 252.

104. Decree of the Presidium of the Supreme Council of the USSR on approval of the Regulation on the procedure for the consideration of labour disputes of 31 January 1957. Vedom. Verkhov. Soveta SSSR, no. 4, 1957. Art. 58.

105. Resolution of the CEC and the CPC of the USSR of 13 October 1929 on the Basics of Disciplinary Legislation of the USSR and Union Republics. SZ USSR, no. 75, 1929. Art. 723.

106. Resolution of the CEC and the CPC of USSR on the liability of employees of institutions and the administrative apparatus of economic bodies for violation of the rules for the general and fire protection of office buildings and premises and the 
One-time gross breach of work duties as the ground for termination of the employment contract at the initiative of the employer

rules for storing official documents of 07 July 1932. SZ USSR, no. 53. 1932. Art. 319.

107. Resolution of Council of Ministers of the USSR on the approval of the Statute on discipline for railway transportation employees of the USSR No. 636 of 31 July 1964. SP USSR, no. 13, 1964. Art. 91.

108. Mishutin, A. N. (Ed.). Commentary on labour legislation. 2nd ed. M.: Yurid. lit., 1967. 856 p.

109. Fundamentals of the Legislation of the USSR and the Union Republics on Labour (approved by Law of the USSR No. 2-VIII of 15 July 1970). Vedom. Verkhov. Soveta SSSR, no. 29, 1970. Art. 265.

110. Decree of the Presidium of the Supreme Council on approval of Regulations on the procedure for considering labour disputes of the USSR No. 6006-VIII of 20 May 1974. Vedom. Verkhov. Soveta SSSR, no. 22, 1974. Art. 325.

111. Resolution of the Plenum of the Supreme Court of the USSR on the application by courts of legislation regulating the conclusion, amendment and termination of an employment contract No. 3 of 26 April 1984. Biul. Verkhov. Suda SSSR, 1984. Art. 329.

112. Law of the USSR on amendments to the Code of Labour Laws of the Ukrainian SSR during the transition to a market economy No. 871-XII of 20 March 1991. Vidomosti Verkhovnoi Rady USSR. Art. 267.

113. Resolution of the Council of Ministers of the USSR on approval of the Statute on discipline for workers employed in hazardous underground conditions No. 974 of 30 November 1976. SP SSSR, no. 1, 1977. Art. 1.

114. Resolution of the Council of Ministers of the USSR on approval of Statute on discipline of railway transport workers of the USSR No. 748 of 7 August 1985. SP SSSR, no. 24, 1985. Art. 123.

115. Resolution of the Council of Ministers of the USSR on approval of Statute on discipline of employees of the Ministry of Atomic Energy of the USSR No. 390 of 2 April 1987. SP SSSR, no. 25, 1987. Art. 87. 
One-time gross breach of work duties as the ground for termination of the employment contract at the initiative of the employer

116. Resolution of the Council of Ministers of the USSR on approval of Statute on discipline of employees of the State Customs Control of the USSR No. 1130 of 9 October 1987. Retrieved from http://www.lawmix.ru/docs_cccp/2511/.

117. Resolution of the Council of Ministers of the USSR on approval of Statute on discipline of workers and employees of ships supporting the navy No. 32 of 9 January 1986. SP SSSR, no. 5, 1986. Art. 31.

118. Law of Ukraine on amendments and addenda concerning the consideration of individual labour disputes to the Labour Code of the Ukrainian SSR and recognition of certain legal regulations as repealed No. 2134-XII of 18 February 1992. Vidomosti Verkhovnoi Rady Ukrainy, no. 22, 1992. Art. 302.

119. Law of Ukraine on amendments to the Labour Code of Ukraine concerning the procedure for dismissal of certain categories of employees No. 3632-XII of 19 November 1993. Vidomosti Verkhovnoi Rady Ukrainy, no. 49, 1993. Art. 461.

120. Law of Ukraine on amendments to Articles 41 and 134 of the Labour Code of Ukraine No. 184-IV of 17 October 2002. Vidomosti Verkhovnoi Rady Ukrainy, no. 47, 2002. Art. 355.

121. Isaiev, Yu. V. Special grounds for termination of the employment contract at the initiative of the employer. Ph.D.'s thesis. T. Shevchenko Kyiv National University. K., 2012. 213 p.

122. Shcherbyna, V. I. Labour Law of Ukraine. K.: Istyna, 2008. $384 \mathrm{p}$.

123. Decree of the President of Ukraine on some measures to optimize the system of central executive bodies No. 726/2012 of 24 December 2012. Ofith. Visn. Prezydenta Ukrainy, no. 35, 2012. Art. 842.

124. Law of Ukraine on amendments to several legislative acts of Ukraine in connection with holding the administrative reform No. 406-VII of 04 July 2013. Vidomosti Verkhovnoi Rady Ukrainy, no. 20-21, 2014. Art. 712.

125. Law of Ukraine on Disciplinary Statute of the Customs Service of Ukraine No. 2805-IV of 06 September 2005. Vidomosti Verkhovnoi Rady Ukrainy, no. 42, 2005. Art. 467. 
One-time gross breach of work duties as the ground for termination of the employment contract at the initiative of the employer

126. Law of Ukraine on Disciplinary Statute of of the Civil Defence Service No. 1068-VI of 05 March 2009. Vidomosti Verkhovnoi Rady Ukrainy, no. 29, 2009. Art. 398.

127. Resolution of the CMU on approval of Regulations on Discipline of railway transport workers No. 55 of 26 January 1993. ZP Ukrainy, No. 4-5, 1993. Art. 71.

128. Tkáčová, D. Selected problems of banking restructuring in the Slovak Republic. BIATEC, no. 1, 1999: 8-10.

129. Sabo, I. Comparative Law. In Criticism of the modern bourgeois. theory of law. V. A. Tumanova (Ed.). M.: Progress, 1969: 165-207.

130. Alekseev, S. S. General theory of law. In 2 vols. Vol. 1. M.: Yurid. lit., $1981.359 \mathrm{p}$

131. Labour Code of the Republic of Belarus (approved by Law of Republic of Belarus No. 296-C of 26 July 1999). Nats. Reestr prav. actov Resp. Belarus, no. 80 (2/70), 1999.

132. Glovanova, V. G., Semenkova, V. I. (Eds.). Commentary on the Labour Code of the Republic of Belarus: Article-by-article application of sample documents. Minsk: Dikta, 2009. $1328 \mathrm{p}$.

133. Civil Code of the Republic of Belarus (approved by Law of Republic of Belarus No. 218-C of 7 December 1998). Vedom. Nats. Sobr. Resp. Belarus, no. 7-9, 1999. Art. 101.

134. Decree of the President of the Republic of Belarus on granting legal entities a deferral of payment of arrears of taxes and penalties No. 292 of 13 August 1996. Collection of Presidential decrees and Resolutions the CM of the Republic of Belarus, no. 23, 1996. Art. 566.

135. Decree of the President of the Republic of Belarus on additional measures to improve labour relations, strengthen labor and executive discipline No. 29 of 26 July 26 1999. Nats. Reestr prav. actov Resp. Belarus, no. 58 (1/512), 1999.

136. Decree of the President of the Republic of Belarus on strengthening the requirements for managers and employees of organizations No. 5 of 15 December 2014. Retrieved from http://president.gov.by/ru/official_documents_ru/view/ dekret-5-ot-15-dekabrja-2014-g-10434. 
One-time gross breach of work duties as the ground for termination of the employment contract at the initiative of the employer

137. Semenkova, V. I. (Ed.). Labour Law. 3rd ed. Minsk: Amalfeia, 2006. $784 \mathrm{p}$.

138. Baburina, S. N. (Ed.). Commentary to the Labour Code of the Russian Federation (article by article). Scientific and practical. With explanations from official bodies and article-by-article materials. 2nd ed. M.: Kn. mir, 2013. 848 p.

139. Resolution of the Plenum of the Supreme Court of the RF on the application by the courts of the Russian Federation of the Labour Code of the Russian Federation No. 2 of 17 March 2004. Bul. Verkhov. Suda RF, no. 6. 2004. Art. 486.

140. Orlovskii, Yu. P. (Ed.). Commentary to the Labour Code of the Russian Federation. 5th ed. M.: Kontrakt: INFRA-M, 2011. $1456 \mathrm{p}$.

141. Statute on discipline of employees of organizations operating particularly radiation-hazardous and nuclear-hazardous production and facilities in the field of atomic energy use (approved by Federal Law of the RF No. 35-FZ of 8 March 2011. Collection of FR Legislation, no. 11, 2011. Art. 1504.

142. Federal Law on the use of atomic energy No. 170-FZ of 21 November 1995. Collection of FR Legislation, no. 48, 1995. Art. 4552.

143. Labour Code of the Republic of Moldova (approved by Law of Republic of Moldova No. 154 of 28 March 2003). Monitorul Oficial, no. 159-162, 2003.

144. Labour Code of the Republic of Lithuania (approved by Law of Republic of Lithuania No. IX-926 of 4 June 2002). Retrieved from http://www.vbfondas.lt/upload/LR_darbo_kodeksas.htm.

145. Shugaev, A. A., Kisterev, D. D. Labour Codes of the Czech Republic and the Russian Federation: Comparative legal analysis. M.: RITS ISPI RAN, 2010. 344 p.

146. Kiselev, I. Ya. Comparative and international labor law. M.: Delo, 1999. 728 p.

147. Demidov, N. V. Dismissal on the initiative of the employer. Ph.D.'s thesis. Tomsk State Ped. Un-ty. Tomsk, 2009. 229 p.

148. Sereda, O. H. Employer as a subject of labor law. Ph.D.'s thesis. Yaroslav Mudryi National Law University. - Kh., 2004. $210 \mathrm{p}$. 
One-time gross breach of work duties as the ground for termination of the employment contract at the initiative of the employer

149. Zaichuk, O. V., Onishchenko, N. M. (Eds.). Theory of State and Law. K.: Jurinkom Inter, 2006. 688 p.

150. Urkevych, V. Yu. Agrarian legal relations in Ukraine. Extended abstract of Doctor's thesis. Yaroslav Mudryi National Law University. - Kh., 2007. 39 p.

151. On reinstatement at work, recovery of the average salary during forced truancy, compensation of non-pecuniary damage (case no. 6-3105sk11). Retrieved from http://reyestr.court.gov.ua/.

152. Resolution of the CMU on establishment of the State Fiscal Service of Ukraine No. 160 of 21 May 2014. Ofitsiinyi visnyk Ukrainy, no. 46, 2014. Art. 1213.

153. Order of the State Statistics Service of Ukraine on approval of the Classification of Public Administration No. 143 of 07 May 2013. Retrieved from http://zakon.nau.ua/doc/?uid=1157.2162.0.

154. Law of Ukraine on fundamentals of National Security of Ukraine No. 964-IV of 19 June 2003. Vidomosti Verkhovnoi Rady Ukrainy, no. 39, 2003. Art. 351.

155. Resolution of the CMU on the Regulation on the State Fiscal Service of Ukraine No. 236 of 21 May 2014 p. Ofitsiinyi visnyk Ukrainy, no. 55, 2014. Art. 1507.

156. Resolution of the CMU on the formation of territorial bodies of the State Fiscal Service and the recognition of some acts of the Cabinet of Ministers of Ukraine as repealed No. 311 of 6 August 2014. Ofitsiinyi visnyk Ukrainy, no. 64, 2014. Art.1765.

157. Customs Code of Ukraine (approved by Law of Ukraine No. 4495-VI of 13 March 2012) Vidomosti Verkhovnoi Rady Ukrainy, no. 44-48. 2012. Art. 552.

158. Argunova, A. M. Legal regulation of labor relations of officials of revenue and duties. Ph.D.'s thesis. Scientific Institute of Legal Framework for Innovation Development of NALS of Ukraine. Kh., 2014. 219 p.

159. Hermanchuk, P. K. Stefaniuk, I. B., Ruban, N. I. et al. State financial control: Review and audit. K.: NVP AVT, 2004. 424 p.

160. Pashchenko, O. P. Legal regulation of the process of financial control (according to the legislation of Ukraine). Ph.D.'s thesis. Nat. Acad. of State Tax. Services of Ukraine. Irpen, 2005. 210 p. 
161. Decree of the President of Ukraine on Regulation on State Financial Inspection of Ukraine No. 499/2011 of 23 April 2011. Ofitsiinyi visnyk Ukrainy, no. 31, 2011. Art. 1325.

162. Mukhataiev, A. A. Legal status and legislative principles of State Financial Inspection in Ukraine. Ph.D.'s thesis. Yaroslav Mudryi National Law University. Kh., 2005. 194 p.

163. Law of Ukraine on Basic Principles of State Financial Control Realization in Ukraine No. 2939-XII of 26 January 1993. Vidomosti Verkhovnoi Rady Ukrainy. no. 13, 1993. Art. 110.

164. Law of Ukraine on Prices and Pricing No. 5007-VI of 21 June 2012. Vidomosti Verkhovnoi Rady Ukrainy, no. 19-20, 2013. Art. 190.

165. Decree of the President of Ukraine on Regulation on the State Inspectorate of Ukraine for Price Control No. 236/2012 of March 30, 2012. Ofitsiinyi visnyk Ukrainy, no. 26, 2012. Art. 969.

166. Resolution of the CMU on the optimization of the system of central executive bodies No. 442 of 10 September 2014. Ofitsiinyi visnyk Ukrainy, no. 74, 2014. Art. 2105.

167. Law of Ukraine on State Statistics No. 2614-XII of 17 September 1992. Vidomosti Verkhovnoi Rady Ukrainy, no. 43, 1992. Art. 608.

168. Resolution of the CMU on approval of Regulation on State Statistics of Ukraine No. 481 of 23 September 2014. Ofitsiinyi visnyk Ukrainy, no. 78, 2014. Art. 2237.

169. Decision of the Constitutional Court of Ukraine in the case on the constitutional appeal of the All-Ukrainian Joint-Stock Bank on the official interpretation of the provisions of paragraph 22 of part one of Article 92 of the Constitution of Ukraine, parts one, three of Article 2, part one of Article 38 of the Code on Administrative Offenses (case on liability of legal entities) No. 7-rp/2001 of 30 May 2001. Ofitsiinyi visnyk Ukrainy, no. 24, 2001. Art. 1076.

170. Holoborodko, V. O. Legal regulation of internal labour regulations. Ph.D.'s thesis. V. Dahl East Ukrainian National Un-ty. Lugansk, 2012. 190 p. 
One-time gross breach of work duties as the ground for termination of the employment contract at the initiative of the employer

171. Law of Ukraine on accounting and financial reporting in Ukraine No. 996-XIV of 16 July 1999. Vidomosti Verkhovnoi Rady Ukrainy, no. 40, 1999. Art. 365.

172. Dondyk, N. Ya. The use of special accounting knowledge in the investigation of economic crimes. Ph.D.'s thesis. National University of Internal Affairs. - Kh., 2004. 207 p.

173. Aivazova, A. Limits of accountant's responsibility: What you need to know. Advokat bukhgaltera, no. 21 (123), 2006: 19.

174. Law of Ukraine on prevention and counteraction to legalization (laundering) of proceeds from crime, financing of terrorism and financing of proliferation of weapons of mass destruction No. 1702-VII of 14 October 2014. Vidomosti Verkhovnoi Rady Ukrainy, no. 50-51, 2014. Art. 2057.

175. Resolution of the CMU on Standard Regulations on the accounting service of a budgetary institution No. 59 of 26 January 2011. Ofitsiinyi visnyk Ukrainy, no. 8, 2011. Art. 372.

176. Order of the Ministry of Labour and Social Policy of Ukraine on approval of Issue 1 "Occupations of workers that are common to all types of economic activity" of Chapter 3 "Occupations of managers, professionals, specialists and technical employees that are common to all types of economic activities" of Qualification characteristics of occupations of workers No. 336 of 29 December 2004. Ukr. Invest. Gas, 45, 2007. Art. 164.

177. Classifier of Occupations DK 003: 2010 (approved by Order of the State Committee of Ukraine on tech. regulation and consumption policy No. 327 of 28 July 2010. Retrieved from http://kadry. at.ua/blog/ klasifikator_profesij_dk_003_2010/2010-11-08-16.

178. Ortynskyi, V. L., Kisil, Z. R. Kovaliv, M. V. Management in the executive authorities of Ukraine. K.: Tsentr. uchb. lit., 2008. $296 \mathrm{p}$.

179. Okhotnikova, O. M. Administrative liability of the head of a public enterprise, institution, organization in Ukraine. Ph.D.'s thesis. Nat. Acad. State Tax. Services of Ukraine. Irpen, 2004. 203 p.

180. Cherepakhin, B. B. Proceedings on Civil Law. M.: Statut, 2001. $479 \mathrm{p}$. 
One-time gross breach of work duties as the ground for termination of the employment contract at the initiative of the employer

181. Law of Ukraine on business associations No. 1576-XII of 19 September 1991. Vidomosti Verkhovnoi Rady Ukrainy, no. 49, 1991. Art. 682.

182. Law of Ukraine on Joint-Stock Companies No.514-VI of 17 September 2008 p. Vidomosti Verkhovnoi Rady Ukrainy, no. 50-51, 2008. Art. 384.

183. Resolution of the CMU on streamlining the contractual form of employment agreement No. 170 of 19 March 1994. Ukr. Invest. Gas., 10, 2003. Art. 174.

184. Resolution of the CMU on the application of the contractual form of employment agreement with the head of the stateowned enterprise No. 203 of 19 March 2005. Ukr. Invest. Gas., 50, 2007. Art. 203.

185. Pavlynska, O. Appointment of the founder as the head. Labour and law, no. 10(166), 2013: 17.

186. Zanfirova, T. A. Legal regulation of labor relations with the participation of the employer - an individual. Ph.D.'s thesis. Yaroslav Mudryi National Law University. Kh., 2004. 224 p.

187. Civil Code of Ukraine (approved by Law of Ukraine No. 435-IV of 16 January 2003). Vidomosti Verkhovnoi Rady Ukrainy, no. 40-44, 2003. Art. 356.

188. Law of Ukraine on state registration of legal entities and individual entrepreneurs No. 755-IV of 15 May 2003. Vidomosti Verkhovnoi Rady Ukrainy, 31-32, 2003. Art. 263.

189. Kuznechenkova, V. E. Tax law-making process in the system of legal categories. Zhurn. Ros. Prava, 1. 2005: 34-37.

190. Matuzova, N. I., Malko, A. V. (Eds.). Theory of state and law. 2nd ed. Moscow: Yurist, 2001. 776 p.

191. Nikolina, K. V. Legal procedure: Concepts, features, types, place in the system of legal categories. Ph.D.'s thesis. Kyiv. University of Law. K., 2011. 215 p.

192. On reinstatement and recovery of average earnings during forced truancy (case no. 6-12596sv07). Retrieved from http://reyestr.court.gov.ua/.

193. Law of Ukraine on trade unions, their rights and guarantees of activity No. 1045-XIV of 15 September 1999. Vidomosti Verkhovnoi Rady Ukrainy, no. 45, 1999. Art. 397. 
One-time gross breach of work duties as the ground for termination of the employment contract at the initiative of the employer

194. Yakovlev, O. A. Termination of the employment contract on the initiative of third parties who are not parties to the employment contract. Ph.D.'s thesis. Yaroslav Mudryi National Law University. Kh., 2003. 189 p.

195. Sereda, O. Duties of employer legal effects of their ignorance. Law of Ukraine, no. 9, 2002: 83-84.

196. Law of Ukraine on local self-government in Ukraine No. 280/97-BP of 21 May 1997. Vidomosti Verkhovnoi Rady Ukrainy, 24, 1997. Art. 170.

197. On reinstatement and recovery of average earnings during forced truancy (case no. 6-22208sv11). Retrieved from http://reyestr.court.gov.ua/.

198. Antsut, E. Dismissal of the head for one-time gross breach work duties. Pratsya i Zakon, 3 (159), 2013: 20. 
NOTES 
Одноразове грубе порушення трудових обов’язків як підстава розірвання трудового договору 3 ініціативи роботодавця : монографія / О. Ю. Дрозд, С. М. Козін. - ЛьвівТорунь : Ліга-Прес, 2020. - 208 с.

\section{ISBN 978-966-397-211-4}

\section{DOI}

Монографію присвячено визначенню місця грубого порушення працівником трудових обов'язків в системі додаткових підстав розірвання трудового договору 3 ініціативи роботодавця, а також науковому обгрунтованню пропозиції й рекомендації з удосконалення нормативноправового регулювання і правозастосовної практики в цій царині.

Наведено науково обгрунтовані пропозиції з удосконалення правового регулювання розірвання трудового договору 3 ініціативи роботодавця у випадку одноразового грубого порушення працівником трудових обов'язків. Визначено, що для полегшення правозастосовної практики необхідно законодавчо закріпити поняття «грубе порушення трудових обов'язків». Наведено перелік категорій працівників, які можуть бути звільнені на підставі одноразового грубого порушення трудових обов'язків, та охарактеризовано процедуру розірвання трудового договору у випадку за такої обставини.

Монографія розроблена для науковців, аспірантів, студентів, практикуючих юристів, та всіх, хто цікавиться проблематикою зазначеної теми.

УДК 349.22:331.106.44

При повному або частковому відтворенні матеріалів монографї будь-якими засобами або в якій-небудь формі, в тому числі в Інтернеті, посилання на видання є обов'язковим 
Publishing house "Liha-Pres"

9 Kastelivka str., Lviv, 79012, Ukraine

44 Lubicka str., Toruń, 87-100, Poland

Printed by the publishing house "Liha-Pres"

Passed for printing: September 17, 2020. A run of 150 copies. 